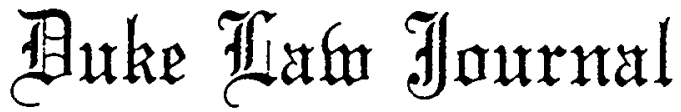

\section{DESIGN PROTECTION IN DOMESTIC AND FOREIGN COPYRIGHT LAW: FROM THE BERNE REVISION OF 1948 TO THE COPYRIGHT ACT OF 1976}

\section{J. H. REICHMAN*}

This is the first of two articles that study the complex interactions of the different branches of intellectual property law that seek to regulate the degree of protection to be accorded ornamental designs of useful articles. A circular pattern can be discerned in the treatment of these designs in both foreign and domestic law. Traditionally, the right to copyright protection is premised on a claim that certain indistrial designs are entitled to legal recognition as art in the historical sense. The economic repercussions of such recognition flow principally from the industrial character of the material support in which ornamental designs are embodied. The incidence of these repercussions upon any given system varies with the extent to which the claim to recognition as art is itself given effect. As copyright protection for designs of useful articles expands, the economic effects of this expansion on the general products market induce countervailing pressures to reduce the scope of protection acquired in the name of art. As protection in copyright law correspondingly contracts, pressure for recognition of industrial art as a legally protectible form of industrial property normally increase. The tendency of industrial property law to breed still further instances of underprotection or overprotection then fosters renewed pressures for the regulation of industrial art within the framework of the laws governing literary and artistic property.

(C) J.H. Reichman 1983

* A.B. Chicago (1955), J.D. Yale (1979); Associate Professor of Law, The Ohio State University; formerly Senior Editor, International Trade Centre, UNCTAD/GATT, Geneva.

This project has greatly benefited from the advice and encouragenent of Professors Ralph Sharpe Brown, Alan Latman, William T. Fryer III, Paul Goldstein, and Charles R. McManis, as well as from the kind assistance of Madame Marie-Angèle Pèrot-Morel, Director, Centre Universitaire d'Enseignement et de Recherche de Propriété Industrielle (CUERPI), University of 
I. Applied Art in the Berne Union: Three Options for THE UNITED STATES .............................. 1145

A. Legitimation of Applied Art in United States Law. .... 1149

B. Legitimation of Applied Art in the Berne Union. ....... 1153

1. The Unity of Art Thesis in France. .............. 1153

2. Revival of the Sui Generis Regime of Design Protection. ................................... 1159

3. The Intractable Problem of Cumulation. .......... 1167

C. Options for the United States. .................. 1170

II. Evolution of THE COPYRIGHT APPROACH FROM MAZER

V. STEIN TO THE GENERAL REvisIon OF $1976 \ldots \ldots \ldots \ldots . .1174$

A. Rise and Fall of the First Noncumulationist Model. ..... 1174

1. Art in the Historical and Ordinary Sense. ......... 1174

2. An Interim Theory of Dissociation. .............. 1182

3. Toward An American Regime of Sui Generis Protection. ............................... 1186

4. A Continuing Theory of Dissociation. ............. 1201

B. The "Unity of Art" Heresy: Its Spread and Vigorous

Repression. .................................. 1213

1. Separability Italian Style. .................. 1213

2. Separability American Style................... 1223

3. The Unity of Art Heresy. ..................... 1238

4. Grand Finale all'italiana. ..................... 1249

a. Toward an American regime of partial cumulation. ................................ 1251

b. Noncumulation without a design law. .......... 1260

Grenoble, France. Moral support came from Professors Guido Calabresi, Al Clovis, Howard Fink, Peter Gerhart, Larry Herman, Michael Kindred, Earl Finbar Murphy, LeRoy Pernell, Michael Perry, and Dr. Paul Dusseau. Student research assistants at The Ohio State University College of Law included Thomas Emsweiler, Dr. Nicholas Kallas, Dr. Randall Hillson, Liza Toth, and Steven Russi, most of whom now practice intellectual property law. Vicki Jenkins and Marc Caldwell provided valuable back-up assistance. Professor Reinhardt Sonnenbergcr's German translations, Judith Sapp's editing, Ruth Kessler's library skills, and Michele WhetzelNewton's typing and editorial assistance are gratefully acknowledged, as is the generous financial support provided by Dean James E. Meeks and the Schwartz Family Fund. All of those mentioned have left their marks on this work and ine in their debt, as have numerous other students, friends, and colleagues whose hclp is no less appreciated. The end product is dedicated to the beloved meinory of Professor Charles A. Thompson.

Many of the sources cited in this work are foreign language sources, only some of which liave official translations. Citations to sources without official translations are followed by parenthetical indications of the translator; when no indication is given, the word "trans." indicates that the translation has been provided by the author, J.H. Reichman. 


\section{Applied Art in the Berne Union: Three Options for the UNITED STates}

The distinctive philosophy of protection that characterizes the laws of literary and artistic property in the Berne Union countries ${ }^{1}$ was extended only gradually, and against considerable opposition, to "works of art applied to industry."' 2 Throughout nuost of the nineteenth century, the separation of "beauty" fron "utility" was an axioun rooted in Enlightenment ideals. ${ }^{3}$ Reformers who attacked "art for art's sake" as an elitist slogan found support for functionahisn in Greek philosophy of art and pointed to Cellini's saltcellars or Raphael's candelabra as proof that art remained art even when apphed to useful objects. ${ }^{4}$ But

1. The Berne Union was created by the Berne Convention for the Protection of Literary and Artistic Works. A valuable source containing most nations' copyright laws is UNESCO \& World Intellectual Property Organization [WIPO], Copyright Laws and Treaties of THE WorLd (1982) [heremafter cited as COPYRIGHT LAws]. The Berne Convention, signed September 9, 1886, appears in 3 CopYright Laws, Multilateral Conventions, Berne Copyright Union, item A-1 [heremafter cited as Berne Convention]; it was revised at Berlin on November 13, 1908, id. at item C-1, 1 L.N.T.S. 217 (1920) [heremafter cited as Berlin Revision]; it was revised again at Rome on June 2, 1928, id. at item E-1, 123 L.N.T.S. 233 (1931) [heremafter cited as Rome Revision]; it was revised again at Brussels on June 26, 1948, id. at item F-1, 331 U.N.T.S. 217 (1959) [hereinafter cited as Brussels Revision]; it was revised again at Stockholm on July 14, 1967, id. at itein G-1, 828 U.N.T.S. 221 (1972) (not entered into force) [heremafter cited as Stockholm Revision]; it was revised again at Paris on July 24, 1971, id. at item H-1, (entered into force July 10, 1974 im accordance with article 28) [hereinafter cited as Paris Revision]. The Enghish texts of the Brussels and Paris Revisions are reproduced in 4 M. NIMMER, NIMMER ON COPYRIGHT, appendices 26 \& 27 (1983). See generally De Sanctis, The International Copyright Conventions, 14 CopyRIGHT 254 (1978).

The United States is not a signatory to the Berne Convention. See $3 \mathrm{M}$. NIMMER, supra, $\S 17.04[\mathrm{D}][1]$, at 17-11 to 17-12; Gabay, The United States Copyright System and the Berne Convention, 26 BuLl. COPYRIGHT Soc'y 202 (1979); Ringer, The Role of the United States in International Copyright Law-Past, Present, and Future, 56 GEo. L.J. 1050, 1058 (1968).

2. S. Ladas, Patents, Trademarks, and Related Rights: National and InTERnational Protection 828-37 (1975); M.A. Perot-Morel, Les Principes de Protection des Dessins ex Modeles dans les Pays du Marche Commun 15-30 (1968); F. Perret, L'autonomie du Regime de Protection des Dessins et Modeles 234-67 (1974); Duchemin, La protection des arts appliqués dans la perspective d'un dépôt communautaire en matière de dessins et modèles industriels, 97 ReVUe INTERNaTionale DU Drort D'AUTEUR [R.I.D.A.] 4, 10-15 (1978); Pérot-Morel, Insuffisance et complexité du régime international des dessins et modèles industriels, reprinted in Les Perspectives D'Un Droit Communautaire en MATIERE DE Dessins et MODELES INDUSTRIELS 49, 56-60 (Centre Universitaire d'Enseignement et de Recherche de Proprieté Industrielle [CUERPI] ed. 1977) [heremafter cited as GRENOBLE SYMPosiUm].

3. F. PERRET, supra note 2, at 11-12, 26-29. In France, the period of separation between the fine arts or "pure arts" and industry was most marked in the seventeenth and eighteenth centuries, when "industry was considered the worst enemy of art." C. CARREAU, MERITE ET Drort D'AUTEUR 191 (1981) (trans.).

4. S. LADAS, supra note 2, at 831; F. PERRET, supra note 2, at 11-12, 17 (citing authorities). 
this lofty discourse ${ }^{5}$ minimized the economic aims of industrial art, which only came into its own when the industrial revolution had made it possible to reproduce useful articles in series and which then assumed the eminently practical task of mcreasmg sales of goods on the general products inarket. ${ }^{6}$ The Berne Union countries, at the Berlin Revision Conference of 1908, inentioned the category of "applied art" for the first time, ${ }^{7}$ but declined to grant ornamental designs of useful articles full protection in the law of literary and artistic property. The Conference left member states free to deal with this controversial subject matter "so far as the domestic legislation of each country allows."

The United States, which has never acceded to the Berne Convention, appeared to go further toward recognizing apphied art under the Copyriglt Act of 1909 than had the Berne Uinon countries at the Ber-

5. The functionalism movement reached its height about 1920 with Henri Van de Velde, Gropius, and the Bauhaus school. See J. HesketT, Industrial Design 19-26, 85-104 (1980); see also A. Braun \& J.J. Evrard, Droit des Dessins et Modeles au Benelux 11-13 (1975).

6. See, e.g., B. ENGlert, GrundzüGe Des Rechtsschutzes Der INDUSTRIellen FORMGEBUNG 22-24 (1978); M.A. PEROT-MOREL, supra note 2, at 16, 29; F. PERRET, supra note 2, at 11,15 . The "lofty discourse" also downplayed what Ladas calls "the crude and ugly aspect" of the imdustrial products of the first half of the nineteenth century. S. LADAS, supra note 2, at 831. But see J. HESKETT, supra note 5, at 23-27. According to Perret, the Depressiou of 1929 obliged manufacturers to give new importance to the appearance of their products. F. PERRET, supra note 2, at 13. In fact, the Depression intensified a process begun mucli earlier. J. HESKETT, supra note 5 , at 11,27 .

7. Applied art is not defined by any copyright legislation, although nearly all domestic copyright laws expressly mention applied art among the works protected. Duchemin, supro note 2, at 6-7. Duchemin considers works of applicd art as "intcllectual works . . [that] differ from graphic and plastic works in that they are no longer completely gratuitous, as solely the expression of the artist's message; they also have a utilitarian aspect." Id. Ulmer considers the gratuitous element to be the essential feature of a work of applied art, E. ULMER, URHEBER- UND VeRLAGSRECHT 146-47 (3d ed. 1980) (stressing necessity of purely artistic elements in additiou to functional aspects); Hubmann and Troller stress the element of individuahity, see H. HubMaNN, URHEBer- UND Verlagsrecht 34, $62-63$ (4th ed. 1978); A. TRoller, Precis du DroIt de la Propriete IMMATERIELLE 108 (K. Troller \& V.J. Vesely trans. 1978). Ladas suggests that "a clear definition of such works is perhaps not possible." S. LADAs, supra note 2, at 833. Von Pilgrim asserts that any definition that tends to separate "applied art" from "fine art" is undesirable. V. von Pilgrim, Der Urheberrechthiche Schutze Der Angewandten Formgestaltung 96 (1971) (unpublished thesis) (available at Frankfort). The lime of demarcation between this category of potentially copyrightable works of "applied art" and noncopyrightable "designs and models" is controversial. See infra notes 123-35 and accompanying text.

8. The Berlin Revision Conference of November 13, 1908, declimed to add works of applied art to the protectible subject matter in article 2, paragraph 1 of the Berne Convention, supra note 1; but in article 2, paragraph 4, this category was mentioned as follows: "Works of art applied to indnstrial purposes shall be protected so far as the domestic legislation of each country allows." See S. LADAS, supra note 2, at 833-36; Duchemin, supra note 2, at 10-11. As a result, member countries were not obliged to protect works of applicd art in domestic copyright laws, "but if they did, they were required to give the same protection to works of applied art originating in other member countries, even though these latter countries did not give any protection to such works." S. LADAS, supra note 2, at 833-34. 
lin Revision Conference of 1908. Congress added the phrase "models or designs of works of art" to the "works of art" otherwise protected in section 5(g) of the 1909 Act as "writings of an author." The drafters of the 1909 Act then deleted a provision limiting protection to "works of the fine arts" that had been in force since 1870, when the definitions of copyrightable subject natter were otherwise greatly expanded. ${ }^{10}$ The liberalizing thrust of the 1909 Act was consistent with the 1903 decision of the United States Supreme Court in Bleistein v. Donaldson Lithographing Co., ${ }^{11}$ which upheld the copyrightability of a circus poster against the contention that art and utility were antithetical. ${ }^{12}$ The Bleistein decision, better known for its statement of the copyright norm prohibiting discrimination on the basis of merit, ${ }^{13}$ also lielped to establish the principle of copyrightability for two-dimensional works of applied art. Section 5(g) of the 1909 Act arguably extended this principle to three-dimensional models. ${ }^{14}$

9. Copyright Act of 1909, ch. $320, \S 5(\mathrm{~g}), 35$ Stat. 1076-77 (codified at 17 U.S.C. $\$ \S 1-216$ (1976)). Although this classification was officially for registration purposes only, it has often been treated by courts as giving substantive meaning to the phrase "writings of an author." Latman, Fifteen Years After Mazer v. Stein: A Brief Perspective, 16 Bull. Copyright Soc'y 278, 278 n.7 (1969).

10. Act of July 8, 1870, ch. 230, § 86, 16 Stat. 198, 212 (repealed 1916); Nolan, An Appraisal of Copyright Protection for Useful Articles, reprinted in ABA-SECTION OF PATENT, TRADEMARK AND Copyright Law, Summary of Proceedings 216, App. D (1982) [hereinafter cited as ABAPTC SYMPosIum]. Pogue states that this Act "prepared the path to overlapping protection" with the design patent law by blurring the "line of demarcation between purely aesthetic articles and useful works of art." Pogue, Borderland-Where Copyright and Design Patent Meet, $52 \mathrm{MicH}$. L. REv. 33, $42-43$ (1953). Testimony by the Librarian of Congress dnring the hearings that led to the 1909 Act supports the position that Congress intended an expansion of coverage by the elimination of the "fine arts" qualification. Hearings Before Comms. on Patents on S. 6330 and H.R. 19,853, 59th Cong., 1st Sess. 11 (1906); see Note, Protecting the Artistic Aspects of Articles of Utility: Copyright or Design Patent, 66 HARv. L. REv. 877, 879 n.16 (1953).

11. 188 U.S. 239 (1903).

12. Certainly works are not the less connected with the fine arts because their pictorial quality attracts the crowd and therefore gives them a real use-if use ineans to increase trade and to help to make money. A picture is none the less a picture and none the less a subject of copyright that is used to advertise soap. . . or . . . as . . . they may be used to advertise a circus.

Id. at 251 (Holnes, J.); see Note, Works of Applied Art: An Expansion of Copyright Protection, 56 S. CAL. L. REv. 241, 252-53, 260 (1982).

13. "It would be a dangerous nndertaking for persons trained only to the law to constitute themselves final judges of the worth of pictorial illustrations . .." Bleistein, 188 U.S. at 251. The general norn in the European Community countries is that "in assessing protectibility no judgment of the aesthetic value should be made." See A. DiETz, CopYright LaW IN THE EuropeAN COMMUNITY: A COMPARATIVE INVESTIGATION OF NATIONAL Copyright LEgISLATION 34 (1978). The anti-inerit norn is expressly codified at article 2 of the French Copyright Law of 1957, 2 Copyright LaWs, supra note I, France, at item 1.

14. See, e.g., Unbreit, A Consideration of Copyright, 87 U. PA. L. REv. 932, 933 (1939); Pogue, supra note 10 , at 43-44. The tenn "model" in foreign literature signifies a threedimensional design. In the United States, the term "design" covers both two-dimensional designs and three-dimensional models, and it is nonnally so used in this article. 
The United States Copyright Office, however, impleniented the 1909 Act as if the statute had adopted the temporizing solution of the Berlin Conference, which mentioned applied art without more. In 1910 , the Copyright Office issued a regulation providing that the term "works of art" included "all works belonging fairly to the so-called fine arts," namely, "paintings, drawings, and sculpture," and that "productions of the industrial arts utilitarian in purpose and character are not subject to copyright registration, even if artistically made or ornamented." 15 Despite an ainendment to this regulation permitting registration of "artistic drawings notwithstanding that they may afterwards be utilized for articles of manufacture,"16 the practice of the Copyright Office until 1949 was to deny registration to any three-dimensional objects that "would fall within the category of multiple commercial production of works of the applied arts."17 This practice was intended to separate design patent law from copyright law and to prevent designers and manufacturers froin circumventing the strict ehigibility requirements for design patent protection by resorting to the less strimgent requirenients of copyright law. ${ }^{18}$

The Copyright Office had thus, by administrative rulemaking, ${ }^{19}$ kept alive the distmction between fine and applied art that the 1909 Act

15. Copyright Office, Rules and Regulations for the Registration of Claims to Copyright, Bull. No. $15, \S 12(\mathrm{~g})$ (1910)(emphasis added), reprinted in Mazer v. Stein, 347 U.S. 201,212 n.23 (1954). The same regulation also provided that "no copyright exists in toys, games, dolls, advertising, novelties, instruments or tools of any kind, glassware, embroideries, garments, laces, woven fabrics, or any similar articles." Id. This policy was contmued in 1917, 1926, and in 17 C.F.R. $\$ 201.4$ (1938). See Pogue, supra note 10, at 44.

16. Copyright Office, Rules and Regulations for the Registration of Claims to Copyright, § 12(g) (1926); Dulin, Design Protection: Walking the Pirate Plank?, 12 Bull. CopyRIGHT SOC'Y 321, 324 n.19 (1965).

17. Derenberg, Copyright No-Man's Land: Fringe Rights in Literary and Artistic Property, 35 J. PAT. OFF. Soc'Y 627, 646 (1953).

18. Pogue, supra note 10, at 44; Note, Copyrighting Works of Artistic Craftsmanship Embodied in Articles of Practical Use, 27 IND. L.J. 130, 130-33 (1951).

For the United States Design Patent Law, see Act of Aug. 29, 1842, eh. 263, 5 Stat. 544 (codified at 35 U.S.C. $\$ \$ 171-173$ (1976)). The American position was similar to those of the Umited Kingdoin (until 1968) and Italy (especially after 1941). See infra note 132; text accompanying notes 204-26.

At this time, the Design Patent Law of 1842, as consolidated in 1870 and revised in 1902, was still being enforced with a degree of liberality. Umbreit, supra note 14, at 934; Nimetz, Design Protection, 15 CoPYRIGHT L. SYMP. (ASCAP) 79, 121-24 (1967). This permissive period ended in the Second Circuit as early as 1916, and in other jurisdictions during the 1930's. Id. at 125-27.

19. Section 207 of the Copyright Act of 1909 permitted the Copyright Office to establish "rules and regulations for the registration of elaims to copyright." The 1976 Act, 17 U.S.C. $§ 702$ (1982), gives the Register of Copyrights substantial rulemaking authority even with regard to policy matters. Latman, Letter from the United States of America, 16 CoPYRIGHT 315, 315-16 (1980). 
had apparently abandoned. ${ }^{20}$ In so doing, the United States copyright authority seemed accurately to interpret the spirit of the Berlin Conference of 1908.21 Then, in 1948 at the Brussels Conference convened to revise the Berne Convention, proponents of legal recognition of industrial art overcame part of the resistance they had encountered at Berlin in 1908. After 1948, member states of the Berne Union could no longer ignore the protectibility of some industrial art under their laws of hterary and artistic property. ${ }^{22}$ As a result, countries outside the Union that had remained hostile to copyright protection for applied art, sucl as the United States, were spurred to review their positions in order to maintain the minimum degree of reciprocity that comity and the exigencies of international trade made advisable. ${ }^{23}$

\section{A. Legitimation of Applied Art in United States Law.}

In December 1948, the United States Copyright Office changed the definition of a "work of art" in Regulation Section 202.8. The new definition included "works of artistic craftsmanship, in so far as their form but not their mechanical or utilitarian aspects are concerned, such as artistic jewelry, enamels, glassware and tapestries, as well as all works belonging to the fine arts." 24 In 1949, the Register published his opmion that mass-produced artistic jewelry could qualify as copyright-

20. Denicola, Applied Art and Industrial Design: A Suggested Approach to Copyright in Useful Articles, 67 MinN. L. Rev. 707, 710 (1983); Note, supra note 10, at 879.

21. This meant that applied art could not have been a major stumbling block in the way of efforts to bring the United States into the Union, see Ringer, supra note 1, at 1055-63, although there was indignation in the Berne Union concerning the failure of the United States generally to accord foreign works the same level of protection available within the Union. Id. at 1060. It also meant that the counterfeiting of foreign designs in the United States was no more disruptive of international copyright relations than were similar practices in certain Berne Union countries, which the Berlin Revision of 1908 had not rendered clearly illegal. For flagrant design piracy in the Netherlands, see, for example, Cohen Jehoram, Specific Design Protection and Copyright in Benelux and Dutch Law, reprinted in DesIGN PROTECTION 21, 24 (1976)(collecting papers delivered at a symposium in Amsterdam in 1975) [heremafter cited as AMSTERDam SyMposium]. Nonetheless, there were outcries in the Uinted States concerning design piracy from both foreign and domestic sources, but these outcries failed to persuade Congress to enact any of the series of design bills that had been proposed since 1904. See Note, Designer Law: Fashioning a Remedy for Design Piracy, 30 UCLA L. REv. 861, 865 (1983). For the problem of dress designs pirated from France, see S. Gotshal, TODAY'S FIGHT FOR DESIGN PROTECTION (1957), reprinted in Hearings on S. 1884 Before the Senate Subcomm. on Patents, Trademarks and Copyrights of the Senate Comm. on the Judiciary, 87th Cong., 1st Sess. 171, 192-95 (1961) [hereinafter cited as Design Protection Hearings 1961].

22. See infra text accompanying notes 98-104.

23. Derenberg, supra note 17, at 630; see also A. DIETZ, supra note 13, at 9-10.

24. Works of art (Class G), 37 C.F.R. \& 202.8(a) (1949). The annual report of the Register of Copyrights for 1948 announced the change by declaring that the Copyright Office would register works of art "if they display artistic features, whether or not . . . they have utilitarian purposes." Pogue, supra note 10 , at 65 n. 152 . 
able works of art on analogy to Cellini's saltcellars; the Copyright Office accepted for registration many three-dimensional works of applied art in the next few years. ${ }^{25}$ By September 6, 1952, when the United States signed the Universal Copyright Convention at Geneva, ${ }^{26}$ this country's domestic law appeared to afford limited recognition to applied art, consistent with treaty obligations and with the future working relations between the Geneva countries and the Berne Union. ${ }^{27}$

Ironically, the federal judiciary, which had upheld the copyrightability of an advertising poster in 1903, resisted the new dis-

25. Derenberg, supra note 17, at 647-48; Warner, Copyrighting Jewelry, 31 J. PAT. OFF. Soc'Y 487,489 (1949).

26. Universal Copyright Convention, 6 Sept. 1952, 3 Copyrighr LAws, supra note 1, at Multilateral Conventions, U.C.C., item A-1, 216 U.N.T.S. 132 (1955), revised at Paris, 24 July 1971 , id. at item B-1, 25 U.S.T. 1343, T.I.A.S. No. 3324, 943 U.N.T.S. 178 (1974). The United States has ratified both Acts. $4 \mathrm{M}$. Nimmer supra note 1, app. 21 .

After the Second World War, it became imperative to "bridge the gap" between members and nonmentbers of the Berne Union. The United States Copyright Office, under Register Arthur Fisher, took a leading role in these efforts, which were sponsored by UNESCO and which resulted in the Universal Copyright Convention. Kaminstem, Arthur Fisher Memorial, in 1 STudies oN COPYRIGHT xiii (1963) [hereinafter cited as Kaminstein, Fisher Memorial]; Ringer, supra note 1, at 1060-61; see also M.A. PEROT-MOREL, supra note 2, at 161 . The spirit of the Geneva Convention is the same as that of the Berne Convention, i.e., to assure a ninimunn level of protection to authors and artists, but with much greater leeway left to national legislation under the Gcneva accord. M.A. PEROT-MOREL, supra note 2, at 167-68. Nevertheless, it was necessary for "[a]dvocates of international copyright protection . . . to lay the groundwork for altering the domestic law in the Umited States." Ringer, supra note 1, at 1061. On the framework created by the two conventions in the modern period, see Ulmer, International Copyright After the Paris Revisions, 19 BulL. CopYrught Soc'Y 263 (1972); De Sanctis, supra note 1; Kaminstein, Report of the Rapporteur of the Conference for the Revision of the Universal Copyright Convention, 19 BuLL. COPYRIGHT Soc'Y 211 (1972) [hereinafter cited as Kaminstein, Rapporteur]; see also 3 M. NIMMER, supra note 1, \& 17.04[B].

27. The Geneva Convention recognized applied art indirectly in conncction with the contplex provisions of article IV that determined the minimum term of protection to be established under the treaty. The broad subject-matter categories of protectible works in article 1 spcak only ' of "literary, scientific and artistic works." M.A. PEROT-MOREL, supra note 2, at 168; Françon, Modele et droits d'auteur, reprinted in PROTEGER LA Forme 96, 98-99 (1981) (collection of papers presented at symposiun in Paris) [hereinafter cited as PARIS SYMPosIuM]. The provisions of article IV(2), pertaining to the duration of protection, are declared inapphicable to applicd art under articie IV(3); this article requires those countries that copyright works of applied art to provide a minimum term of ten years of protection. M.A. PEROT-MOREL, supra note 2, at 168; S. LADAS, supra note 2, at 835 . With this proviso, a primciple of reciprocity was established in article IV(4), according to which works treated as apphed art in both the country of origin and the receiving country would be granted protection for the period established by the law of the country of origin. S. LADAS, supra note 2, at 835; M.A. PEROT-MOREL, supra note 2, at 169.

The net result is that works of applied art are presumed to be included within the broad category of "artistic works" protectible under article I, but if a inember country chooses to protect such works only by means of a sui generis design law, it has not violated the Convention. Françon, PARIS SYMPOSIUM, supra, at 99. The operational differences between the Geneva Convention and the Berne Convention as regards applied art were then further reduced through the work of intergovernmental committees. M.A. PEROT-MOREL, supra note 2, at 170; see also De Sanctis, supra note 1, at 256-57, 261; Ringer, supra note 1, at 1064. 
pensation. Most courts clung to the art versus utility dichotomy that the Copyright Office had stubbornly maintained for nearly forty years despite the express liberalization of the 1909 Act. $^{28}$ In the words of Professor Derenberg, judicial scrutiny of the new regulation thus resulted in a rude awakening for those "who had assumed that, by registering such objects as works of art or designs for works of art, they had actually acquired copyright protection." 29

When the United States Court of Appeals for the Fourth Circuit heard Stein v. Mazer, ${ }^{30}$ the Copyright Office intervened with an amicus brief contending that the statuettes of male and female dancing figures were entitled to copyright protection under the 1909 Act despite their commercial use as lamp bases. ${ }^{31}$ The Fourth Circuit, relymg heavily on this brief, upheld copyrightability. ${ }^{32}$ The Suprene Court of the United States affirmed the Fourth Circuit's decision in the landmark case of Mazer v. Stein, ${ }^{33}$ which validated Regulation Section 202.8 and established for the first time the protectibility of applied art in United States copyright law. ${ }^{34}$

The issue for a majority of the Supreme Court was not whether a manufacturer had the right to register a lamp base but rather whether an artist's right to copyright a work of art was compromised by his intention to apply that work of art to mass-produced useful articles. ${ }^{35}$ The Court answered in the negative, because the creator of a picture or

28. Latman, supra note 9, at 279. The courts had largely ignored the liberalization of the 1909 Act in section 5(g). Note, Protection for the Artistic Aspects of Articles of Utility, 72 HARv. L. REv. 1520, 1524 (1959). Of seven decisions in the early 1950's concerning the copyrightability of statuettes used as bases for table lamps, three had upheld copyrightability and four had not. Stein v. Expert Lamp Co., 96 F. Supp. 97 (N.D. Ill. 1951) denied copyrightability, was affirmed by the Seventh Circuit, 188 F.2d 611 (7th Cir. 1951), and was denied certiorari, 342 U.S. 829 (1951). Similarly, Stein v. Benederet, 96 U.S.P.Q. (BNA) 13 (E.D. Mich. 1952) denied copyrightability. The Sixth Circuit stayed an appeal until after the Supreme Court decision in Mazer v. Stein, 347 U.S. 201 (1954), and then found copyrightability. Stein v. Benaderet, 214 F.2d 822 (6th Cir. 1954). In contrast, Stein v. Rosenthal, 103 F. Supp. 227 (S.D. Cal. 1952) upheld copyrightability and was affirmed by the Ninth Circuit, 205 F.2d 633 (9th Cir. 1953). In Stein v. Mazer, 111 F. Supp. 359 (D. Md. 1953), copyrightability was rejected; but the Fourth Circuit reversed on appeal, 204 F.2d 472 (4th Cir. 1953), and the United States Supreme Court granted certiorari, 346 U.S. 811 (1953).

29. Derenberg, supra note 17 , at 648 .

30. 204 F.2d 472 (4th Cir. 1953), aff'd, 347 U.S. 201 (1954).

31. See Pogue, supra note 10, at 56. The Copyright Office opposed the criterion of the artist's "intention" as administratively impracticable and also contended that design patent law and copyright law were not mutually exclusive. In so doing, it rejected the "intended use" doctrine then current in United Kingdom law. See infra note 132.

32. Stein v. Mazer, 204 F.2d 472, 477 (4th Cir. 1953), aff d, 347 U.S. 201 (1954).

33. 347 U.S. 201 (1954).

34. Id. at 205-08. How firm the court's intention was to expand $\S 5(\mathrm{~g})$ of the 1909 Act is unclear. Compare Dulin, supra note 16, at 321, 325 and $1 \mathrm{M}$. NIMMER, supra note $1, \S 2.08[\mathrm{~B}]$, at 2-88 with Note, supra note 28, at 1525 (talks of "dicta") and Denicola, supra note 20, at 712, 715.

35. Mazer, 347 U.S. at 205. 
a statue was an author whose "writings" fell within the constitutional enabling clause. ${ }^{36}$ The Court held that the distinction between "fine arts" and "useful works of art" had ended with the 1909 Act's deletion of the fine arts clause of the 1870 Act. ${ }^{37}$ Because the statutory authority to protect "works of art" and "reproductions of works of art" encoinpassed the statuettes in question, they could not be excluded by judginents concerning their aesthetic value or by "a narrow or rigid concept of art."38 Moreover, the potential patentability of the statuettes as lamps did not bar their copyrightability as works of art, even though the United Kingdom had reached the opposite result. ${ }^{39}$ "The dichotomy of protection for the aesthetic is not beauty and utility but art for the copyright and the invention of original and ornamental design for design patents." 40

The decision in Mazer $v$. Stein had a "revolutionary impact" that took some time to make itself felt. ${ }^{41}$ With Mazer, the United States acquiesced in the proposition, formally honored by nost of the world, that an ornamental design did not necessarily cease to be artistic when embodied in a useful article. ${ }^{42}$ But the Mazer Court never addressed

36. Id. at 207-08; see also COPYRIGHT OFFICE, SECOND SUPPLEMENTARY RePORT OF THE Register of CopyrightS ON THE GENERAL ReVISION OF THE U.S. COPYRIGHT LAW: 1975 REVISION BILL, ch. VII, at 8-10 (1975 Draft) [hereinafter cited as REGISTER's DRAFT REPORT 1975].

37. Mazer, 347 U.S. at 212 . In its amicus brief the Copyright Office admitted to having stretched the letter of its own regulation on some 60 occasions by allowing registration of "works of art possessing utilitarian aspects." Id. From this the Court derived "a contemporaneous and long-contimued construction of the statutes by the agency charged to administer them that would allow the registration of such a statuette as is in question here." Id. at 213 . In fact, what the Register had conceded was that, prior to 1948, an object "im a standard art form," such as a sculpture or painting, would not be turned away merely because the Copyright Office had reason to know of its "possible utilitarian aspects." See Pogue, supra note 10, at 65 n.152 (quoting Register of Copyright's amicus brief to the Fourth Circuit).

38. Mazer, 347 U.S. at 214 ("Individual perception of the beautiful is too varied a power to permit a narrow or rigid couception of art.").

39. Mazer, 347 U.S. at 217. The defendant had urged the Court to follow then current United Kingdom law. See infra note 132. See generally Note, supra note 28, at 1526-27 (arguing for strict separation of design patent law from copyright law, but recognizing "inference of a congressional purpose to allow utilitarian objects protection under either scheme').

Umbreit beheved that the apphication to design patents of the precedents of mechanical patents rather than of copyrights was an "accident of administration"; and that the overlapping of subject matter, which had occurred since very early times, reflected "the tendency to extend the protection of copyright to things which in their nature cannot be the subject of a copyright." Umbreit, supra note 14, at 934-35. The doctrime of election was rejected by the Court of Customs and Pateut Appeals, In re Yardly, 493 F.2d 1389, 1394 (C.C.P.A. 1974); see Frijouf, Simultaneous Copyright and Patent Protection, 23 CoPYRIGHT L. SYMP. (ASCAP) 99, 113-14 (1977).

40. Mazer, 347 U.S. at 218.

41. See REgister's DRAFt RePORT 1975, supra note 36, at 10.

42. This is viewed as the narrow holding of Mazer $v$. Stein. Note, supra note 28, at 1525. Unless this proposition is accepted, copyrightability of even a traditional work of art can turn on the nature of the inaterial support or on the end use to which the work is put. This, in turn, creates 
the related problem that some, many, or most ornamental designs might not rise to the level of protectible works of applied art. Perhaps the traditional art form of the statuettes obscured this issue; 43 .or perhaps the Court assumed that the nondiscrimination principle of Bleistein dictated a very broad definition of a work of art.44 The Supreme Court's failure to determine the legal criteria by which a candidate for protection as applied art should establish its credentials as a work of art in the first instance thus begged the very question that had split the Berne Umion into three camps at the Brussels Conference of $1948 .{ }^{45}$

\section{B. Legitimation of Applied Art in the Berne Union.}

1. The Unity of Art Thesis in France. The copyright approach to mdustrial $a^{46}$ rests on the notion that ornamental designs of useful articles should not be denied protection as artistic works merely because of their industrial character. A cultural and political bias in favor of gratuitous art or "art for art's sake" fueled resistance to this proposition. ${ }^{47}$ It is now clear, however, that copyright protection of aesthetic designs affects competition between useful articles whose legal status is otherwise determined by the laws of industrial property. ${ }^{48}$ The

tension with the "work" as the basic unit of protection in modern copyright law. See, e.g., A. Dietz, supra note 13, at 33-34; F. PERRET, supra note 2, at 240-42; cf. Copyright Act of 1976, 17 U.S.C. \& 102(a) (1982)("works of authorship").

43. Latman, supra note 9, at 278-79 ("On the other hand, the Court may simply have recognized the impossibility of defining 'art' in a meaningful way as a matter of law.").

44. $1 \mathrm{M}$. NiMMER, supra note $1, \S 2.08[\mathrm{~B}]$, at 2-88 ("The Mazer opimion can be read to mean that any useful article, at least if it is aesthetically pleasing in appearance, is subject to copyright protection with respect to its form."). Professor Nimmer's reading is essentially consistent with the "unity of art" thesis developed in France; see infra notes 60-78 and accompanying text; infra note 347. The Copyright Office did not read Mazer this way.

45. "In recent years an important problem has arisen as to whether ornamental designs of useful articles (also referred to as 'apphied art' or 'industrial designs') conie within the category of copyrightable 'works of art." " HouSE COMM. ON THE JUdiciary, 87TH CONG., 1st Sess., REPORT OF THE REgister of COPYRIGHTS ON THE GENERAL REVISION OF THE U.S. COPYRIGHT LAW (Comm. Primt 1961), reprinted in 3 OMNibus Copyright Revision Legislative History 12 (1976) [hereinafter cited as REGISTER's REPORT 1961]. A Swiss observer in the 1960's predicted that the Mazer Court's failure to establish suitable criteria would cause problems later on. $H$. Secretan, La Protection des Dessins et Modeles Industruels et des Oeuvres D'art Applique auX ETATS-Unis ET en Suisse-ETude du Droit Compare 124-25 (1964).

46. See infra note 147 and acconpanying text.

47. See, e.g., F. PERRET, supra note 2, at 11-12, 26-29; E. ULMER, supra note 7, at 146; V. von Pilgrim, supra note 7 , at 85-90, 92-94, 102-11.

48. The individual design or model reflects both technical imperatives linked to the nethod of manufacture and functional exigencies. See, e.g., Gaubiac, La théorie de l'unité de l'art, 111 RIDA 2-3 (1982); Perret, La protection des créations de formes utilitaires ou fonctionelles dans le cadre d'un droit spécifique communautaire, reprinted in GRENOBLE SYMPOSIUM, supra note 2, at 139-40. Designs and nrodels are also destmed to be reproduced in series; their commercial exploitation is largely determined by factors governing the market segment in which the useful object is to be sold rather than by economic factors operating on the market for works of art as such. 
laws governing industrial property, including patent, trademark and, since the eighteenth century, sui generis design laws, ${ }^{49}$ obey different legal principles that drive nost useful articles toward free competition. ${ }^{50}$ As Madame Pérot-Morel observed in 1968, industrial art is a legal hybrid that different legal subcultures subject to conflicting and sometimes irreconcilable demands. ${ }^{51}$

During the nineteenth century, French courts recognized that "art applied to imdustry" could aspire to legal protection as art.52 Sui generis design protection was also established im France at a very early date. ${ }^{53}$ For nearly a century, French courts and commentators struggled to establish a strict line of demarcation between designs that deserved protection as "pure art" under the Frencli copyright law of 1793 and those that deserved only the protection afforded by the special design law of 1806.54 Between 1806 and 1902 France experimented with five different criteria for distinguishing the subject inatter of these two regimes: 1) the inethod of reproduction, ${ }^{55}$ 2) the purpose or end use of the design, ${ }^{56} 3$ ) the secondary or accessory character of the aesthetic features, ${ }^{57} 4$ ) the status of the creator, ${ }^{58}$ and 5) the relative artistic value

M.A. Perot-MOREL, supra note 2, at 18-22; Benussi, Droit Italien, reprinted in GreNoble SYMPOsIUM, supra note 2, at 118; Strunkmann-Meister, Leistungsschutz und industrie form, 66 ARCHIV FUR URHEber-, FuNk-, uND TheaterRecht [UFITA] 63, $64-67$ (1973); $c$. Note, Present Design Protection in the United States, 5 Bull. COPYRIGHT SOC'Y 139-40 (1958)(this note is by an anonymous professional author) [hereimafter cited as Present Design Protection]; Register's RePoRT 1961, supra note 45, at 13.

49. The first legislation on designs seems to have been a British Act of 1787 "for the encouragement of the arts of designing and printing lineus, cottons, calicoes and muslins." S. LADAS, supra note 2, at 829 . The Frencl design law of 1806, liowever, first made "imdustrial designs . . . a brancl of industrial property . . . and it was this law which was copied or imitated all over the world." Id.

50. Wallace, Design Protection in the United Kingdom, reprinted in AMSTERDAM SYMPOSIUM, supra note 21 , at 40 .

51. M.A. PERot-Morel, supra note 2, at 16.

52. Finniss, The Theory of "Unity of Art" and the Protection of Designs and Models in French Law, 46 J. PAT. OfF. Soc'y 615, 618-19 (1964).

53. See supra note 49.

54. See P. Greffe \& F. Greffe, Traite des Dessins et des Modeles 4-6 (rev. ed. 1974); Finniss, supra note 52, at 616-17; Gaubiac, supra note 48 , at $42-49$.

55. This criterion distinguisled between handcrafted items, which were copyrightable, and works reproduced by mechanical means, which were not. Gaubiac, supra note 48, at 44-45.

56. Creations intended for industrial reproduction were protected by the law on designs and models. Id. at 44-45. For the difficulties of implementing this criterion without inconsistencies and without damage to the concept of the work, see id. at 44-46; Fimiss, supra note 52, at 619-20. The purpose or destination test, which Frencl courts abandoned prior to 1902, became popular outside of France and still influences a number of European systems. Id. at 619-21; see F. PERRET, supra note 2 , at $240-42$.

57. Gaubiac, supra note 48 , at $46-47$. This criterion, reportedly proposed by Philippon in Traitè de la Propriété des Dessins et des Modeles Industriels (1880), stressed the gratuitous nature of art "applied" to industrial objects as distinct from designs determined by the utilitarian object 
of the candidate design. ${ }^{59}$ French courts found all of these criteria difficult to apply; in the end, their inconsistent and increasingly arbitrary decisions ${ }^{60}$ paved the way for Pouillet's attack on the validity of drawing any line of deinarcation whatsoever. ${ }^{61}$

Pouillet and his followers argued that there could be no discrimination as to the degree of legal protection accorded different forms of aesthetic creativity, and that all creations were entitled to protection in the law of literary and artistic property:

Whence comes the difficulty that is found in clearly defining the nature and character of the industrial design and model? It comes . . . from the fact that we have got it in our heads that art and industry, two things made to be allied and urited, should be separated, and because we have dreamed of establishing a line of demarcation between them. ${ }^{62}$

Pouillet therefore rejected all such distinctions as necessarily based on judges' subjective assessments of aesthetic inerit:

It is a remarkable thing that as long as the question is that of appreciating a work conceived through the inspiration of purely abstract and speculative thought, everyone is in agreement concerning the principle of the unity of art . . ., but as soon as an application of

itself. See F. PERRET, supra note 2, at 242; Gaubiac, supra note 48, at 46-47. In practice, the task of determining whether a design was predominantly industrial or merely decorative in nature proved too difficult for the Freuch courts even in the nineteenth century, i.e., before industrial aesthetics began to integrate form and function. Gaubiac, supra note 48, at 46-47.

58. "If the creator was a manufacturer, the law of designs and models was to apply . . . if he was an artist, the law of artistic property apphed." Gaubiac, supra note 48, at 46-47. But a distinction between manufacturers and artists breaks down im the case of artisans and becounes meaningless if the manufacturer is also an artist or when the artist transfers the rights of reproduction to a firm. Id.

59. The subjectivity and insufficiencies of the first four criteria led the French courts, in the final phase of this pre-1902 period, to experiment with overt subjectivity, i.e., a test of the artistic level of the work in questiou. Finniss, supra note 52, at 621; Gaubiac, supra note 48, at 48-49. This criterion was quickly rejected as leaving "the ordinary man to the whim of law courts." Perot-Morel, Specific Protection of Designs and Its Relation to Protection by Copyright in French Law, reprinted in AMSTERDAM SYMPOSIUM, supra note 21, at 49; see also Gaubiac, supra note 48, at 48-49. Nevertheless, artistic value is perhaps the most frequently used criterion in the European Community today. See infra notes 281-83 and acconpanying text.

60. M.A. Perot-Morel, supra note 2, at 42-45; Desbois, Le système français: La théorie de l'unité de l'art, reprinted in GRENOBLE SYMPOSIUM, supra note 2, at 74.

61. E. Poulliet, Traite Theorique et Pratique de Propriete Litteraire et ArtisTIQUe ET DU DRoit DE Representation (2d ed. 1894) [hereinafter cited as E. Poulliet, Propriete artistique]; E. Poulllet, Traite Theorique et Pratique Des Dessins et Modeles (5th ed. 1911) [hereinafter cited as E. Poulllet, Dessins ET Modeles]. According to Algardi, Pouillet was anticipated by Huard. See Z.O. Algard, Disegno Industriale E ARTe APPLICATA 65-66 (1977).

62. E. Poulllet, Dessins et MOdeles, supra note 61 , at 49 (trans.). Despite its role in ornamenting merchandise and in influencing the consumer's choice, the industrial design is seen as a creation of the spirit, sonetimes a creation of genius. Id. at 51-53 (referring to works of art apphed to useful articles by Michelangelo, Cellini, and Raphael). 
art is involved, as soon as an immediate and direct use of the object appears indicated, then the most disparate opinions emerge and, with the help of strong feelings, the result is the worst inconsistencies and the most unexpected contradictions. ${ }^{63}$

Pouillet's "theory of the unity of art" 64 gained legislative recognition in both France ${ }^{65}$ and Belgium. ${ }^{66}$ Viewing attempts to estabhish a rational line of deinarcation between the design law and the copyright law as futile, Pouillet maintained that decorators, painters, sculptors, and fashion designers were all artists whose works uniformly deserved to be governed by the copyright paradigin. ${ }^{67}$ Under Pouillet's influence, French copyright law, as amended in 1902, extended protection to "designers of ornainents, whatever inay be the inerit and the purpose

63. Id. at $51 \mathrm{n} .1$ (the English translation is available in Gaubiac, supra note 48, at 60), 50-53.

64. This theory criticized legal distinctions between true artistic designs and lesser designs. See E. Poullet, Dessins Et Modeles, supra note 61, at 49-54; see also Finniss, supra note 52, at 615-16.

65. See Gaubiac, supra note 48, at 4-7 (1902 amendinent to 1793 Copyright Law protected "sculptors and designers of ornaments . . . whatever may be the merit and purpose of the work"); Finniss, supra note 52, at 616-17. This was reconfirmed by the design law of July 14, 1909, which amended the law of 1806 and accepted the unity of art thesis in Article 1. Gaubiac, supra note 48, at 4-5. Nevertheless, some courts and coinnientators continued to resist implementation of this thesis until much later. Id at 6-7. A special law of March 12, 1952, repressed the counterfeiting of clothing designs and other products of seasonal industries; it expressly endorsed the unity of art principle in article 1. Id. The principle was further consolidated by the French copyright law of Marcl 11, 1957, 2 CopYright Laws, supra note 1, France, item 1 (protecting "authors" of "all intellectual works, regardless of their kind, forn of expression, merit or purpose" (art. 2)); the Cour de Cassatiou silenced the remaining resistance with a series of decisions in the 1960's. P. GREFFE \& F. GREFFE, supra note 54, at 25-35. The ascendancy of the umity of art thcsis as a matter of law is no longer contested in France. Desbois, supra note 60, at 63-77. But see F. Greffe, L'application de la loi du 11 Mars 1957, PARIS SYMPOSIUM, supra note 27, at 114-22 (reporting new resistance by French courts not unlike the resistance to the copyright approacl that emerged in the United States Court of Appeals for the Second Circuit in 1976). See Reichman, Design Protection After the Copyright Act of 1976: A Comparative View of the Emerging Interim Models, $31 \mathrm{~J}$. CopYRIGHT Soc'Y 267, 312-21 (No. 3, Feb. 1984)(forthcoming) [hereinafter cited as Reichman, After the Copyright $A c t]$.

66. The unity of art thesis was officially adopted in Belgium by Royal Decree of January 29, 1935, which extended copyright proteetion under the law of March 22, 1886 "to all productions of forin, from the most lumble to the most sublime." A. BRAUN \& J.J. EvRARD, supra note 5, at 15. The unity of art principle in Belgium, however, was rejected by article 21 of the Uniform Benelux Designs Law, which took effect January 1, 1975. See infra notes 281,610 and accompanying text; Reichman, After the Copyright Act, supra note 65, at 283-97.

67. E. Poullete, Dessins et Modeles, supra note 61, at 52-54; see also C. CARreau, supra note 3, at 198-202; Pérot-Morel, supra note 59, at 47. In reahty, strenuous efforts were made to limit the unity of art thesis by insisting on a distinction between non-art and art, a distinction that some leading commentators believe Pouillet himself had accepted. See, e.g., P. GREFFE \& F. GREFFE, supra note 54, at 24; Pérot-Morel, supra note 59, at 47. But see E. PoullLET, DESSINS ET MODELES, supra note 61 , at 52 . In the end, the failure to arrive at defensible distinctions of this kind led to the broadest applicatiou of the unity of art thesis in France. P. GREFFE \& F. GREFFE, supra note 54, at 24, 35-38; Pérot-Morel, supra note 59, at 47-49. 
of the work."68 By the 1930's, despite pockets of judicial resistance, French law had rejected every test of aesthetic creation that "would allow industrial art to be separated from real art." 69 Consequently, originators of "all creations of form, even the most modest," obtain a generous bundle of economic and moral rights for a term of life plus fifty years from creation, and need not comply with any formal prerequisites whatsoever, such as notice, registration, or deposit.70

Despite the triumph of the unity of art thesis, the French legislature did not repeal the special design law of 1806. Instead, the legislature passed the design law of July 14,1909 , still in force, ${ }^{71}$ which further refined the advantages conferred by sui generis legislation with respect to establishing proof of ownership, facilitating transfers of title, and restricting competition. ${ }^{72}$ The umity of art principle, expressly con-

68. See supra note 65.

69. Finniss, supra note 52, at 623-24; Pérot-Morel, supra note 59, at 47 . The ascendency of the unity of art thesis is attributed, however, to the inadequacy of other solutions rather than to its intrinsic persuasiveness. See, e.g., M.A. Perot-MoreL, supra note 2, at 44-45; F. PerRET, supra note 2, at 243-46. The desirability of continuing unlimited protection of industrial art in French copyright law has been challenged in recent years. See, e.g., Perot-Morel, supra note 59, at 62-65. But see Françon, supra note 27, at 102-03. See generally Gaubiac, supra note 48, at 2-3, 12-43, 6070. Pressure on the border with patent law is also reported. See Pérot-Morel, Protection of Designs and How It is Related to the Law on Patents in France, reprinted in AMSTERDAM SYMPOSIUM, supra note 21, at 67-78 [hereinafter cited as Pérot-Morel, Designs and Patents]; see also infra text accontpanying notes 83-87.

70. P. GREFFE \& F. GREFFe, supra note 54, at 35-38; Desbois, supra note 60, at 64-66; Finniss, supra note 52, at 615 .

71. Law on Designs and Models (Design Statute), July 14, 1909, as amended most recently by Decree of April 24, 1980, English version reprinted in UNESCO \& UNITED INTERNATIONAL BureauX for the Protection of Industrial Property and of Literary and ARTISTIC Works[BIRPI], Design LaWs and Treaties OF THE WORLd (A. Bogsch ed. 1969-1971), France item 1 [hereinafter cited as DESIGN LAWs]; see also Designs AND UTILITY MOdels Throughout THE WORLD 129-32 (A.M. Greene ed. 1983)(summary of provisions in English) (hereinafter cited as Designs AND Utility Models]. The French design law of July 14, 1909, confers a maximum of fifty years of protection on objects that are rendered distinctive by features of shape and configuration or by other exterior effects. Such designs must be novel and, to a certain extent, qualitatively original in the patent sense. In principle, the protection afforded by the design law is absolute. In practice, protection depends on a showing of bad faith, and sanctions cannot be invoked against an infringer without prior deposit and registration. The French law differs from those of other European Community countries in that the act of deposit and registration does not create the right to protection under the French design law; it serves to establish the date of creation and a presumption of ownership. Divulgation without deposit does not destroy novelty under the design law in France (within the European Community, this is true only of France); and deposit may be made at any time. A secret deposit, valid for 25 years, is also permitted. Desbois, supra note 60, at 64-66; Duchemin, Les difficultés relatives a l'organisation d'un dépot communautaire en matière de dessins et modeles industriels, reprinted in GRENOBLE SYMPOSIUM, supra note 2, at 173-203. See generally P. GrefFe \& F. GReFFe, supra note 54. French design law, which cunulates with the French copyright law, is atypical. See Duchemin, supra, at 180-81 (coniparative table); see also infra notes 74-78 and acconipanying text.

72. Finniss, supra note 52 , at $618,626-28$. 
firmed by the law of 1909 and later by the copyright law of March 11, 1957,73 gave designers and manufacturers the opportunity to cumulate the advantages of both acts without penalizing thein for failing to take one route or the other in any given case. ${ }^{74}$ Provided that a design were registered under the design law of 1909, the provisions of this law might fully satisfy the owner's legal needs. If, for one reason or another, his attempt to invoke the design law proved abortive or otherwise insufficient, the owner could simultaneously invoke the protection of copyright law in the very action for infringement under the design law. ${ }^{75}$ If, finally, the creator had ignored the design law altogether, his entitlement to copyright protection from the date of creation would not suffer inerely because special design protection might have been available had he taken the pains to meet the requirements of registration and deposit. ${ }^{76}$

The unity of art thesis in France produced two results of primary importance from the comparative standpoint. First, it led France to extend copyright protection to all industrial art, including commercial designs "on the lower frontier of apphied art" that "depend on what is called industrial aesthetics."77 Second, it led to gradual integration of the copyright law and the special design law into what is technically described as a regime of absolute or total cumulation. ${ }^{78}$

73. See supra note 65.

74. "The principle of the unity of art not only entails an option (to choosel between the two statutes; but also the swo statutes may be cumulated to the fullest extent save where their respective provisions are incompatible." Desbois, supra note 60, at 66 (emphasis in original)(trans.)

75. Desbois, supra note 60, at 66-74; Finniss, supra note 52, at 626-28. For example, the design could fail to meet the substantive prerequisites of the design law; or the photographic reproduction submitted for deposit could fail to reveal its salient features; or the initial deposit, valid for five years, might not have been renewed in time. The unity of art principle, by permitting absolute cumulation between copyright and design law, avoids loss of rights against an imfringer in such cases. Desbois, supra note 60, at 66-68; P. GREFFE \& F. GREFFE, supra note 54, at 36. Even when a deposit under the design law has been properly accomplished, the owner might prefer to invoke the moral rights or the strong remedies of French copyright law, not to mention the longer duration it confers. Pérot-Morel, supra note 59, at 52-53. Copyright law also confers penal sanctions, rights of succession, and procedural advantages not available under the design law. Id. at $54-56$.

76. See Desbois, supra note 60, at 66; Pérot-Morel, supra note 59, at 57.

77. Finniss, supra note 52, at 615; Pérot-Morel, supra note 59, at 57-58 ("The artistic character is not considered").

78. Perot-Morel, supra note 59, at 52 (although it is "remarkable to apply two different laws to one object," the principle of cumulative protection is the necessary consequence of the unity of art theory). France is the only country within the European Community that affords the possibility of total cumulation between copyright law and a special regime of design protection. Duchemin, supra note 2, at $42-43$.

Cumulation between copyright and design law in the French system is not a two-way street in the sense that not every "creation" protected by the 1957 copyright law is qualificd to invoke special design protection under the 1909 law. Desbois, supra note 60, at 73. 
2. Revival of the Sui Generis Regime of Design Protection. If Pouillet's "simple but seminal" idea ${ }^{79}$ eventually prevailed in France, the soundest writers caution that it was a victory by default rather than by persuasion. ${ }^{80}$ The chief virtue of this position was that it eliminated arbitrary distinctions between pure and industrial art that French jurisprudence found unworkable and then intolerable. ${ }^{81}$ Nevertheless, the "unity of art" theory continues to elicit skepticism even in France. ${ }^{82}$ Many of those moved by Pouillet's evocation of Cellini were dismayed to see the laws of hiterary and artistic property expand to protect the designs of such articles as plastic salad bowls, drinking glasses, fireplace grates, a hair brush, the luggage rack of a notor scooter, and the hexagonal head of a lubricating pump..$^{83}$

The unity of art doctrine glossed over the affinity of ornamental designs of useful articles to industrial property, ${ }^{84}$ an affinity recognized by the Paris Union at the International Convention for the Protection of Industrial Property in 1883.85 Arguably, France and Belgium, which

79. E. Poulllet, Dessins et Modeles, supra note 61 , at 54.

80. See, e.g., F. PERRET, supra note 2, at 246 (a makeshift solution); see also supra note 69.

81. Desbois, supra note 60 , at 74 (the unity of art thesis "avoid[s] controversies discouraging for their subtlety and imconsistent decisions on the merits.") (trans.).

82. See supra note 69. Difficulties attributed to this theory, besides the breadth of protection as such, include the long term of protection; the application of moral rights to industrial designs; the complex status of employee designs and designs made for hire; the severity of the copyright remedies; and the lack of notice to third parties owing to the absence of formal requirements in the copyright law of the Berne Union. See generally Gaubiac, supra note 48, at 12-43. Intensive efforts to reform the French system liave been conducted since the 1970's, without success. PérotMorel, supra note 59, at 63-64. For the latest survey, see Gaubiac, supra note 48, at 60-65.

83. See, e.g., P. GreFFe \& F. GREFFE, supra note 54, at 30-31; Pérot-Morel, supra note 59, at 57, 61; Reichman, After the Copyright Act, supra note 65, at 284-88 (breadth of protection in Belgium between 1935 and 1975).

84. The industrial desigu is often seen as an analogue of the utility patent owing to its effects on commerce, and its legal status has been "influenced to a certain degree by the characteristic primciples of industrial property law." M.A. Perot-MOREL, supra note 2, at 16. But see Umbreit, supra note 14 , at $934-35$.

85. The Convention of Paris, signed in 1883, established the International Umion for the Protection of Industrial Property, to which some 92 states have adlered, including the United States. See 22 INDUS. PRop. 6-8 (1983)(table of member states). This treaty was revised in 1900 at Brussels, in 1911 at Washington, and in 1925 at The Hague, 74 L.N.T.S. 289, 1 WIPO, MANUAL of INDUSTRIal PRoperty Conventions [heremafter cited as INDUSTRIal Property ConvenTIONS], item D-1; it was further revised in 1934 at London, 192 L.N.T.S. 17, 1 INDUSTRIAL PropERTY CONVENTIONS, supra, item E-1; it was further revised in 1958 at Lisbon, 828 U.N.T.S. 107, 1 INDUSTRIAL PROPERTY CoNVENTIONS, supra, item F-1; and it was further revised in 1967 at Stockholm, 828 U.N.T.S. 305, 1 INDUSTRIAL ProperTy Conventions, supra, item G-1 (for English versions of the 1934, 1958, and 1967 texts, see also DESIGNS AND UTILITY MODELS, supra note 71 , at 427,439 , and 453 ).

Article 1, paragrapl 2 of the Paris Convention of 1883 recognized "industrial designs and inodels" as a separate branch of industrial property, and this Convention contmues to set minimum standards for the regulation of industrial designs within the framework of international industrial property law. See 1 Industrial Property Conventions, supra, item A-1. 
had sought to rescue artistic designs from the exigencies of patent law, ${ }^{86}$ were now converting copyright law into a de facto industrial property law without the characteristic safeguards of the industrial property paradigm. ${ }^{87}$ Moreover, critics observed that many of the items that French copyright law protected displayed no aesthetic creativity whatsoever. ${ }^{88}$ Such claims, though open to debate in imdividual cases ${ }^{89}$ reinforced suspicion that applied art suffered from a chronically low degree of creative content, due in part to the subordination of aesthetic features to technical exigencies and to the marketmg methods characteristic of a consumer economy .90

86. S. LADAS, supra note 2, at 832-33; Duchemin, supra note 2, at 28-29. Ladas summarizes the dissatisfaction with the patent-law paradigm as follows:

The requirements for novelty, the refusal to protect designs on the ground that their appearance was often connected with an industrial result, the conditions for deposit, and the administrative procedure of examination in many countries-all of these with the consequent expense of obtaming protection-seemed inconsistent with the character of their creations and their value.

S. LADAS, supra note 2, at 832.

The "requirements for novelty" mentioned by Ladas normally include a "qualitative originahty" test (akin to nonobviousness), as this term is used in the present article. See generally" Duchemin, supra note 2, at 17-29, 65-73.

87. "[T] he theory of the unity of art entails an undermining of the [Copyright] Law of 1957 and an ahgnment with the law of industrial property." Gaubiac, supra note 48, at 40-41. Moreover, "industrial and cominercial exploitation, the chief characteristic of designs and models, makes the [Copyright] Law of 1957 hard to apply." Id.; see also Pérot-Morel, Les projets communautaires en matière de dessins et modeles ornamentaux, Conference at the University of Pavia, Nov. 26-27, 1979 (concerning "aspects of the international evolution of industrial property law"), reprinted in 30 Rivista DI DIRITTO INDUSTRIale 378-93 (1981) [hereinafter cited as Pérot-Morel, Pavia Conference?.

88. The following is a typical expression of dismay:

One should not forget that this theory was spawned by a false conflict between art and mdustry. By evoking scholastic examples of Benvenuto Cellini's saltcellar or candelabra by Raphael, one has supposedly justified drawing into the orbit of copyright law a body of miellectual products that bear only an apparent reseinblance to the creations covered by this regime.

F. PERRET, supra note 2, at 246 (trans.); see also A. BRAUN \& J.J. EVRARD, supra note 5, at 14-15; see also Duchemin, supra note 71, at $191-92$ (quoting Vittorio De Sanctis); Pérot-Morel, stupra note 59, at 58-59 (quoting Plaisant).

89. See, e.g. , Desbois, supra note 60 , at 66-67; see also Wallace, supra note 50 , at 39:

The intellectual property world is divided into patent inen and copyright men. . . . Copyright men know hitle about patents and do not nind. They are content to let the patent men get on with it so long as they don't interfere with copyright. Patent men, on the other hand, know a little about copyright, and of what they do know, they disapprove. . . . [To thein] copyright men were grasping: they wanted too long a period of protection; they wanted it for matter which was sometimes quite devoid of novelty; they considered they were entitled to protection as a matter of natural justice, regardless of ... the public interest ... ; and they wanted it without even taking the trouble to prepare and deposit a specification setting out what they claimed to own (or, perhaps preferably, to employ someone to do it for them).

90. The minimally creative design "on the "lower' frontier of applied art," Fmniss, supra note 52 , at 615 , las proved troublesoine since at least the nimeteenth century. See, e.g., Gaubiac, supra note 48, at 60-63; Ljungman, The New Nordic Design Legislation under Comparative Aspects, 4 INT'L Rev. OF INDUS. Prop. \& COPYRIGHT L. [1IC] 336, 342-43 (1973)(low degree of creativity 
Other inembers of the Berne Uinon viewed with increasing diffidence this expansion of protectibility in France and Belgium under the unity of art thesis. ${ }^{91}$ Opponents of the copyright approach intensified efforts to distinguish applied art froin noncopyrightable "industrial designs" on conceptually tenable grounds. ${ }^{92}$ Two dominant positions emerged. One, typified by Italy, insisted on the "duality of art." On this view, ornamental designs were normally ineligible for copyright protection because their dependence on useful articles inade them priinarily objects of cominerce and deprived them of the independent existence deemed a basic attribute of true works of art. ${ }^{93}$ The second position, typified by Germany, conceded copyright protection to a limited number of exceptional designs but rejected the rest as lacking the requisite degree of artistic intensity or value. ${ }^{94}$

It should be stressed that countries opposed to the unity of art thesis did not automatically relegate designs excluded from copyright law to the public domain. Both Germany and Italy, while subscribing to different exclusionary criteria, agreed in primciple that designs of useful articles should be regulated by sui generis design laws modeled on the French design law of $1806 . .^{95}$ These sui generis design laws ${ }^{96}$ placed

produces risk of identical creations). At the time Pouillet wrote, moreover, mass-produced industrial articles were unsightly and product standardization had not occurred. With an extreme degree of technical standardization, not foreseeable in Pouillet's time, the influence of the marginally differentiated design component on consumer decisions has increased dramatically. See, e.g., F. PERRET, supra note 2, at 11-15; J. HeskeTr, supra note 5, at 68-84, 127-44; Bowen, Design Patents and Modern Industrial Designs, 37 J. PAT. OfF. Soc'y 744, 748-52 (1955); Dalsimer, New Concepts of Design Protection, 8 IDEA 168, 168-69 (1964)(Eighth Annual Public Conference of the Patent, Trademark, and Copyright Research Institute). On the depersonalization of modern design and its legal implications, see Reichman, After the Copyright Act, supra note 65, at 276-83 (discussing the views of Hubmann and Strunkmann-Meister).

91. See, e.g., Reimer, The Relations between Copyright Protection and the Protection of Designs and Models in German Law, 98 R.I.D.A. 36, 40 (1978)(The Tribunal of the Empire in Germany rejected the unity of ant thesis in 1911, despite positive views of commentators); see also infra note 210 and accompanying text (Italian courts disregarded the unity of art thesis despite favorable provisions in the Italian copyright law of 1925). Outside the Berne Union, opposition was equally intense. At the Hague Conference of 1925, for example, "the British and American delegations were unwilling to accept the principle of cumulative protection of works of art by the Copyright and Industrial Property laws," and a French proposal to this effect "was not insisted upon." S. LADAS, supra note 2, at 836. Foreign literature often speaks of the "excesses" of the copyright approach to ornamental designs. See, e.g., Pérot-Morel, supra note 59, at 59.

92. See, e.g., S. LADAS, supra note 2, at 837-38.

93. M.A. PEROT-MOREL, supra note 2, at 21, 89-111.

94. Id. at 69-88.

95. See supra note 49.

96. Germany enacted such a design law (Geschmacksmuster) in 1876. See Englert, The Law of Industrial Designs in Germany-Actual State and Reform Proposals, 12 IIC 773 (1981). For Enghsh text, see Law Concerning Copyright in Designs (Design Statute) of 11 January 1876, DEsIGN LAws, supra note 71, Federal Republic of Germany, item 1; see also Utility Model (Gebrauchsmuster) Act of 1968, as amended to 1980, reprinted in 6 IIC STUDies: GERMAN INDUS- 
ornainental designs within a hybrid legal framework, heavily influenced by patent law, that seemed consistent with the industrial character of the useful articles in which any artistic components were embodied.

The legal status of industrial art thus varied from country to country, despite the broad multilateral conventions that otherwise regulated artistic property on the one hand and industrial property on the other.97 The 1948 Brussels Conference to Revise the Berne Convention did not eliminate either the tension or the impediments to trade caused by such inconsistent treatınent. Participants in the Conference were unable to reach a consensus regarding the unity of art thesis promoted by France. Consequently, their attempt to systenıatize the international regulation of imdustrial art ended in an awkward compromise. ${ }^{98}$

Legitimation of applied art within the Berne Convention was a key element of this compromise. Works of applied art were expressly imcorporated within the broad list of protectible subject matter set forth in article 2 of the 1948 revision.99 From the French perspective, this left no doubt that works of applied art were henceforth to be "viewed broadly as artistic works." 100

Adherents of other views succeeded in imposing two major reservations. Each country in which protection was sought acquired the right to limit the duration of copyrights in apphed art. ${ }^{101}$ In addition,

TRIAL PROPERTY, COPYRIght AND ANTITRUST LAWS 68-75 (English translation) (hereinafter cited as IIC STUDIEs]. For a nontechnical, capsule summary of both acts, see DESIGNS AND UTILITY MODELs, supra note 71 , at $135-41$.

Italy enacted its design law in 1868. This law was revised by Decree No. 1411 on Models and Designs of August 25, 1940, as amended May 23, 1977 and June 27, 1979 (Decree No. 338). The 1940 law covers both ornamental designs and models and utility models. M. FABIANI, MODELLI E Disegni Industriali 9-10 (1975). For English texts, see Design Statute, Design Laws, supra note 71, Italy, item 1 [heremafter cited as Italian Design Law of 1940]; for a nontechnical, capsule summary, see DESignS AND UTiLITY MODELS, supra note 71 , at 185-88.

97. Pérot-Morel, Pavia Conference, supra note 87, at 379-80.

98. Françon, PARIS Symposium, supra note 27, at 98-99. See generally Pérot-Morel, GrENoBLE SYMPosium, supra note 2, at 49-61. The copyriglit approach to apphed art, urged by France, was most strongly resisted by Italy. Id. at 57.

99. After 1948, the relevant portion of article 2(1) declared that the "term 'literary and artistic works' sliall mclude every production in the hterary, scientific and artistic domain, whatever may be the mode or form of its expression, such as . . . works of apphed art." Brussels Revision, supra note 1 .

100. S. LADAS, supra note 2, at 834; Françon, PARIS SYMPosium, supra note 27, at 98.

101. Article $7(1)$ provided that "[t]he term of protection granted by this Convention shall be the life of the author and fifty years after his death." Brussels Revision, supra note 1. But the duration of protection for works of apphed art was governed by article 7(3): "In the case of . . . works of applied art, the term of protection shall be governed by the law of the country where protection is claimed, but shall not exceed the term fixed in the country of origin of the work." Id. (emphasis added). Within the European Community, only Luxembourg has in fact limited the 
national governments retained authority to define the apphed art to be protected by doinestic copyright law, and to distinguish between this category of apphed art and a subcategory of "designs and models" that could be subjected to more restrictive regimes. ${ }^{102}$ States electing to exercise this option could then deny copyright protection to a foreign design protected as apphed art in the country of origin by finding that the design did not qualify as applied art under the territorial law of the receiving state. Moreover, in derogation of the basic right of national treatment under the Convention, a receiving state that might otherwise have recognized foreign designs as applied art under territorial law would nonetheless deny copyright protection if the designs were protectible only as "industrial designs or nodels" in the country of origin. ${ }^{103}$ In short, the 1948 text of the Berne Convention admitted applied art to full standing as copyrightable subject matter but author-

duration for applied art, to a period of fifty years from creation. See Duchemin, supra note 2, at 8-9, 73-93.

102. Article 2(5) of the Brussels text of 1948 replaced article 2(4) of the previous text. Article 2(5) provides:

It shall be a matter for legislation in the countries of the Umion to determine the extent of the application of their laws to works of applied art and imdustrial designs and models, as well as the conditions under which such works, designs and models shall be protected.

Works protected in the country of origin solely as designs and models shall be entitled im other countries of the Union only to such protection as shall be accorded to designs and models in such countries.

Brussels Revision, supra note 1.

103. Articles 2(5), 4(1) \& 5, Brussels Revision, supra note 1; Derenberg, supra note 17, at 629 30; Ducliemin, supra note 2, at 10-15; Pérot-Morel, Grenoble SyMPosium, supra note 2, at 58. Member states were thus allowed to draw the kind of demarcation line that had been abolished de facto in France and de jure in Belgium. S. LADAs, supra note 2, at 834; see supra notes 66,78 . This resulted in "the great diversity of legislation . . . and the even greater uncertainty [that subsists] at the international level." Duchemin, supra note 2, at 12-13.

This compromise was nodified as regards implementation but not as to principle at the Stockholm Revision Conference of July 14, 1967. See S. LADAS, supra note 2, at 835; Duchemin, supra note 2, at 14-15 (art. 2(5) of 1948 text became art. 2(7) of 1967 text, which added language mandating copyright protection for foreigu designs in a receiving meinber country that lacked any sui generis design law at all). Moreover, article 7, paragraph 4 , as revised, expressly reaffirmed the right of nember states to limit the period of protection for applied art, but nonetheless establisled a minimum term of 25 years from the date of creation. Stockholm Revision, supra note 1; PérotMorel, Grenoble Symposium, supra note 2, at 59-60. In most cases, this did not require meinber states to protect more items as applied art than before, but only to confer a duration of at least 25 years on those items they did protect. Duchemin, supra note 2, at 14-15; see supra note 101 . With specific regard to the Benelux countries, however, articles $2(7)$ and $7(4)$ did aim to enlarge copyright protection for Italian designs, because these countries possessed no special design laws at the time and Italy protected designs only under a desigu law. See Duchemin, supra note 2, at 14-15. The Benelux countries agreed, in 1966, to adopt the Uniform Benelux Designs Law, which took effect on 1 January 1975. See infra note 117; Reichman, After the Copyright Act, supra note 65, at 283-97.

The Paris Revision of 1971, which entered into force on Jnly 10,1974, carried forward the dispositions regarding applied art as they appeared in the 1967 text. See Paris Revision, supra note 1 . 
ized—or indeed invited-nembers to curb the excesses of the copyright approach by recourse to the kind of subsidiary legal framework that the Paris Convention for the Protection of Industrial Property had long recognized. ${ }^{104}$

The decisions of the Brussels Conference in 1948 profoundly influenced the evolution of design protection law in both inember and nonmember countries. Within the Berne Union, the movement to absorb industrial designs and models into the law of artistic property lost a momentum it never regained. ${ }^{105}$ Sui generis design laws, long the "neglected relative" of industrial property law, were assigned a new role. 106 The growing economic importance of design, the high costs of development and promotion, and the enormous losses froin misappropriation in a field in which "counterfeitimg is endemic" elicited pressures for more effective protection in every country, pressures that partly account for the spread of the copyright approach in the first instance. ${ }^{107}$ Special design laws could alleviate fears of overprotection and excessive restraints of trade evoked by this approach, ${ }^{108}$ and could provide legal safeguards lacking in copyright law. ${ }^{109}$ This, however, presupposed both inodernization of these laws and their universal adoption. ${ }^{110}$

104. Françon, PARIS SYMposıum, supra note 27, at 98-99. This solution, within the double framework of the two conventions, was "both illogical im principle and difficult to implement." Pérot-Motel, GRenoble Symposium, supra note 2, at 61 (trans.).

105. S. LADAS, supra note 2, at 837.

106. Id. at 828; Bogsch, Towards a More Effective Protection of Designs in the United States of America, 1959 Indus. PROP. Q. 3, 14.

107. M.A. Perot-Morel, supra note 2, at 19; F. Perret, supra note 2, at 13-19; Bassard, La Contrefaçon et la manière dont se protègent en France, créateurs et cntrepreneurs, reprinted in PARIS Symposium, supra note 27, at 66 " "Counterfeiting is a phenoinenon in full expansion. It tends to operate on an international and industrialized scale.")(trans.); see also J. HESKETT, supra note 5, at 184, 199-200. For evidence of similar pressures in the United States, see especially Fisher, The Operations of the Copyright Office (address before the ineeting of the ABA Section of Patent, Tradeunark and Copyright Law, August 30, 1960), reprinted in PRoceEdings of THE ABA-SeCTION OF PATENT, Trademark \& COPYRIGHT LAW 202, 206-07 (1960) [heremafter cited as Fisher Address] (economic importance of protecting new appearance designs from fast-moving copiers).

108. See, e.g., Fisher Address, supra note 107, at 207-08 ("there are grave dangers in the tendency of courts to apply the doctrines of copyright to this whole field of design"); see also S. LADAS, supra note 2, at 832-33 (copyright is simple to obtain and of long duration, but protects only against copying; design law is normally of short duration, but clains to protect against independent creation as well).

109. "[T]he view in the world (and I believe the predominant view in the United States) is that when you apply design to functional objects-that is, to objects which convey something more than their own appearance-you need a specialized law with a relatively short term." Fisher $A d$ dress, supra note 107, at 207; see also S. LADAS, supra note 2, at 837-39; supra note 50 and accoinpanying text; infra note 121 .

110. M.A. Perot-MoreL, supra note 2, at 18-19. 
The Lisbon Conference to Revise the Paris Convention took the first step in this direction in 1958 by adopting a new article providing that "industrial designs shall be protected in all the countries of the Union."111 All member countries were thereafter obliged to ensure a reasonable degree of design protection within the framework of the Paris Convention, altlough each country remained free to determine the nature, subject matter, and conditions of such protection. ${ }^{112}$ The second step was taken on November 28, 1960, with the revision and simplification of the Hague Arrangenent of 1925, whicls permits a single international deposit of protected designs. ${ }^{113}$ The third step was to try to standardize national design legislation ${ }^{114}$ through a world-wide effort to develop a model design law, or at least an agreed set of principles that would furtler the goals of uniformity and modernization. ${ }^{115}$

111. Article 5 quinquies, Paris Convention (1958), supra note 85.

112. See Duchemin, supra note 2, at 28-29; see also Design Protection Hearings 1961, supra note 21, at 156 (testimony of Federico, acknowledging need for a United States design law to satisfy general provisions of Paris Convention as revised at Lisbon).

113. The Hague Arrangemeut of 1925 , which provides nachinery for eliminating the disadvantages and expense of separate deposits in each member country, is now administered by the World Intellectual Property Organization (WIPO) in Geneva. This Arrangement, despite its practical importance, has had hittle effect on the unification of national legislation. Duchemin, supra note 2, at 32-33. See Hague Arrangement on the International Deposit of Industrial Designs or Models, November 6, 1925, 74 L.N.T.S. 341; amended at London, June 2, 1934, 205 L.N.T.S. 179, 1 Industrial Property Conventions, supra note 85, at item A-1; revised at The Hague, November 28, 1960 (not yet in force), I INDUSTRIAL Property ConvenTions, supra note 85, at itenu B-1. A deposit under the Hague Arrangement produces in the contracting countries the same effects as if the designs and nodels had been directly deposited there on the date of the international deposit. This deposit is also entitled to the six nonth priority period instituted by the Paris Convention. Duchemin, supra note 2, at 32-33. The Revision of 1960 imdertook techurical modifications with a view to greater harmonization of national design laws and also with the hope of making the Arrangement accessible to many more countries. Id.

114. The Conference at The Hague was preceded by the work of a high-level group of experts that aroused "great expectations." Ljungman, supra note 90, at 336-37. In the United States, Register Fisher declared that, "in colmection with the Hague diplomatic meeting . . . numerous states are considering revising their domestic design laws as we are . . . [E]ssentially, the Hagne revision is a very simple thing, but it illustrates, with respect to our domestic problens, the worldwide interest in this whole situation." Fisher Address, supra note 107, at 207.

The task of reconciling different viewpoints proved too difficult, however, and the 1960 text never entered into force. Ljunginan, supra note 90, at 337. "It appears to have hittle chance of being applied within the near future." Duchemin, supra note 2, at 32-33. G. Finniss, Director of the French Natioual Institute of Industrial Property, was Vice-President and Rapporteur General of the Diplomatic Conference for Revising the Hague Arrangement on Designs and Models. Finmiss's strong views in favor of the unity of art thesis, see generally Finniss, supra note 52, nnay have influenced developments in the United States during the 1960's, but could not have facilitated the task of reconciling different national viewpoints. For the use of Finniss's views in the United States, see Hearings on S. 1237 Before the Subcomm on Patents, Trademarks, and Copyrights of the Comm. on the Judiciary, 88th Cong., 1st Sess. 41, 48-49 (1965)(testimony and statement of Ellis Arnall) [hereinafter cited as Design Protection Hearings 1965].

115. "This reform movement takes place on both the national and the international level . . . . [O]n the international level, the movement toward better design protection is, so to speak, a 
This reform movement culminated in the Tokyo Resolution of the International Association for the Protection of Industrial Property (AIPPD) in $1966^{116}$ and in a new generation of design laws enacted $\mathrm{m}$ many countries. ${ }^{117}$ As late as 1968 , Mme. Pérot-Morel pointed out that many important countries had no special design laws at all while most countries retamed inadequate legislation. By 1978, Mme. Englert found the protection of industrial designs "in a state of radical change,"

total one . . ." Bogsch, supra note 106, at 11-13. Among the various groups of experts at work was a subcommittee of the European Community's Coordinating Committee for Harmonizing the Law of Industrial Property (President of the Coordinating Committee was again G. Finniss, Director of the French National Institute of Industrial Property). This subcommittee produced a report by Professor Roscioni, then Director of the Italian Patent Office; the Roscioni Rcport, however, elicited no follow-up action from the Coordinating Committee. B. ENGLERT, supra note 6, at 22, 26; Duchemin, supra note 2, at 65-73. For echoes of the Roscioni Report in the United States, see infra note 260 and acconpanying text.

The International Association for the Protection of Industrial Property (AIPPI) began a inajor study project in 1959, as did the International Literary and Artistic Association (ALAl), while the World Intellectual Property Organization started work on a model law for developing countries, conpleted in 1969. Duchemin, supra note 2, at 65-73; see Model Law for Developing Countries on Industrial Designs (1969), 3 SourCes of International UNIForm Law, 257-66 (K. Zweigert \& J. Kropholler eds. 1973) [hereinafter cited as SouRCeS OF INTERNATIONAL UNIFORM LAW ].

Even the centrally planned economies, grouped under the Council for Mutual Economic Assistance (CMEA), were developing model design protection laws, although at a slower pace. The result was the Agreenent on the Legal Protection of Inventions, Industrial Designs, Utility Models and Tradeniarks in the Framework of Economic, Scientific and Technical Cooperation, signed at Moscow on Deceinber 4, 1973, reprinted in 3A SOURCES OF INTERNATIONAL UNIFORM LAW, supra, at 524 (signatories include Bulgaria, Cuba, Czechoslovakia, G.D.R., Hungary, Mongolian P.R., Poland, Romania, U.S.S.R.).

In the United States, neeanwhile, the Copyright Office was keeuly interested in these reforms. "The problein of appropriate protection for ornanental designs of useful articles-or what is sometimes and less exactly called industrial design-is not restricted to the United States, but is worldwide in extent. Most of the developed nations are now giving consideration to the matler . ..." Hearing on S. 2075 and S. 2852 Before the Subcomm. on Patents, Tradentarks, and Copyrights of the Senate Committee on the Judiciary, 86th Cong., 2d Sess. 56 (1960)(statement of Arthur Fisher, Register of Copyrights) [heremafter cited as Design Protection Hearings 1960].

116. S. LADAS, supra note 2, at 868-71; Englert, supra note 96, at 773. The Tokyo resolution set forth a statement of basic points that should enter into the formation of a nodern design law. S. LADAS, supra note 2, at 869.

117. See, e.g., Nordic Design Laws, reprinted in 10 INDus. Prop. 223-40 (1971)(English version)(effective in 1970 in Denmark, Norway, and Sweden, and in 1971 in Fiuland); Uniform Benelux Designs Law, signed as part of the Benelux Designs Convention on October 25, 1966, effective January 1, 1975, reprinted in 13 INDus. PROP. 177-83 (1974)(English version); Order on Industrial Designs, January 17, 1974, German Democratic Republic, reprinted in 14 INDUs. ProP. 144-54 (1975)(English version); Statute on Industrial Designs and Models No. 539 of June 8, 1981, effective January 1, 1982, Union of Soviet Socialist Republics, reprinted in WIPO, INDUSTRIAL Property Laws and Treaties, Soviet Union, itein 4-0001 (Enghish version), 22 Indus. Prop. (June 1983)(attachnent); Protocol on Patents and Industrial Designs withn the Framework of the Industrial Property Organization for English-Speaking Africa (ESARIPO), December 10, 1982, reprinted in WIPO, Industrial Property Laws aNd Treaties, Multilateral Treaties, item (1)(B)(ii), 22 IndUS. PROP. (Marcl 1983)(attachnent). 
as a result of which leading countries in all political and economic blocs, including the centrally planned economies and the developing countries, had either enacted new design laws or given high priority to the reform of existing laws. ${ }^{118}$

It cannot be said, however, that these reform efforts have led to the coherent systein of design regulation anticipated after the decisions of the Paris Union in 1958.119 The number of designs deposited under domestic design laws has been relatively sinall in relation to the number of designs launched on the inarket each year. ${ }^{120}$ Further, the technical solutions devised by various committees of experts have not succeeded in eliminating the drawbacks of the "patent approach" that traditionally make design protection costly, slow, and admmistratively inconvenient, as well as of uncertain legal effectiveness. ${ }^{121}$ Above all, the Berne Union's inability to establish a clear line of deinarcation between apphed art protectible in copyright law and industrial designs protectible in sui generis design law has undermined even those achievements that did einerge froin twenty-five years of reform efforts. 122

3. The Intractable Problem of Cumulation. The legal history of industrial art in the twentieth century may be viewed as a continuing effort to establish special regimes of design protection without unduly derogating from the general principles of copyright law. ${ }^{123}$ The diff-

118. B. ENGlert supra note 6, at 26; M.A. Perot-Morel, supra note 2, at 18-19.

119. Duchemin, supra note 2, at 34-39, 74-75 ("no truly satisfactory system of national protection exists [vithin the European Community]"). At an imternational synuposium at Grenoble im 1977, not a smgle speaker was willing to defend his national systenı of design protection. PérotMorel, Pavia Conference, supra note 87, at 389.

120. Duehemin, supra note 2 , at 35 . Systelnatic design piracy, conducted on an international scale, has become a inajor problem. See, e.g., Bassard, supra note 107, at 66.

121. Duchemin, supra note 2, at 35-39, 73-93; Duchemin, Grenoble SyMPOSIUM, supra note 71 , at 184-85. Design protection laws normally require deposit or registration without prior divulgation. Id. at 175-83. Although the requirement of a search of the prior art has been eliminated in most countries, novelty is always required and qualitative originality (akin to nonobviousness) is usually required. B. ENGLERT, supra note 6, at 56-60, 78-84.

122. See, e.g., Gaubiac, supra note 48, at 2-3, 48-49; Pérot-Morel, Grenoble Symposium, supra note 2, at 61. "[T] here is no subject matter within the doniain of industrial property that has elicited such diverse and sometimes confused ideas, and suclı a multiplicity of efforts yielding so little success." M. FABIANI, supra note 96, at 121 (trans.).

123. See Gaubiac, supra note 48, at 48-59; Reichman, After the Copyright Act, supra note 65, at 365-86. The chief disadvantage of the Brussels compromise concerning applied art was that it gave new impetus to the very line-drawing exercises that had ultimately led to adoption of the unity of art thesis im France. Any line of demarcation "implies the existence of a no-1nan's land" of greater or lesser importance depending on the criteria used. Ducliemin, supra note 2, at 62-63; see Reichman, After the Copyright Act, supra note 65, at 313-21 (discussing L. Batlin \& Son $v$. Snyder). Moreover, every satisfactory criterion, according to the French view, inust account for the fact that "the most stunning objects are exhibited at the Museum of Modern Art in New York" 
culty of this task becomes apparent when it is recalled that, within the Berne Union, works of art original in the copyright sense ${ }^{124}$ obtain long-term protection without formalities, whereas under special design laws, only short-term protection is normally available for novel and qualitatively original designs deposited or registered prior to divulgation. ${ }^{125}$ Even the inost technically refined design laws can govern only those designs that fall within their jurisdictional sweep. The harder a country makes it to obtain copyright protection for industrial art, the more that country's special design law may determine the scope of the design protection actually available within that system. If a country makes it easy for industrial art to qualify for copyright protection as applied art, designers will have less incentive to make use of a special design law and design protection will increasingly be characterized by the copyright approach. The true scope and effectiveness of any given design law will therefore depend on the extent to which the scope of protection it affords, and the conditions it imposes, are undermined by the concurrent availability of copyright protection for industrial art. At the saine time, measures needed to limit concurrent protection are likely to derogate froin general primciples of copyright law. ${ }^{126}$

Hindsight suggests that the reform of sui generis design laws after 1958 was thwarted by the decisions inade at Brussels in 1948, which hardened the preexisting attitudes toward applied art and converted cumulation into "the biggest problem of all for the protection of designs and models." 127 Cumulation means that concurrent protection is available for ornamental designs of useful articles in copyright and special design law. ${ }^{128}$ When concurrent protection is always possible, as in the French regime of absolute cumulation, special design laws serve as optional methods of augmenting manufacturers' rights, without forfeit-

and that everyday useful articles figure prominently in private art collections. Franel \& Gaubiac, Prolegomenes, reprinted in PARIS SYMPOSIUM, supra note 27, at 15.

124. Normally, this means independent creation. Duchemin, supra note 2, at 76-79. But in the case of designs protected as "apphed art" states may require a degree of creativity that surpasses mere independent creation. See F. PERRET, supra note 2, at 85-89; infra note 131 and accompanying text.

125. Article 4(2) Brussels Revision, supra note 1; Article 5(2) Paris Revision, supra note 1. "Design law generally requires that a design be both novel and original-concepts borrowed from patent law." Cohen Jehoram, Design Laws in Continental Europe and Their Relation to Copyright Law, 8 European Intellectual Property Review [ElPR] 235, 236 (1981).

126. See, e.g., Gaubiac, supra note 48, at 58-61 ("Whereas it appears necessary to make a certain distinction, it is impossible to implement it."); Pérot-Morel, Le droit comparé et ses enseignements, reprinted in PARIS Symposium, supra note 27, 137-38, $145-46$.

127. Franel \& Gaubiac, supra note 123, at 18; see supra text accompanying notes 98-104.

128. S. LADAS, supra note 2, at 840; M.A. PEROT-MOREL, supra note 2, at 30; Cohen Jehoram, supra note 125 , at 235 . 
ing protection against copying under the law of artistic property. ${ }^{129}$ When, as in the Italian regime of noncumulation, there is virtually no possibility of concurrent protection for ornamental designs and models, short-term protection in a special design law becomes the only safe route regardless of the degree of artistic content. Italian manufacturers locked imto the design law can lose all protection if they fail to ineet its formal and substantive prerequisites, which reflect a modified patentlaw paradigm. ${ }^{130}$ When partial cumulation is practiced, as in the Federal Republic of Germany, the Benelux countries, and the Scandmavian countries, manufacturers occasionally obtain copyright protection for designs and models that manifest exceptional creativity. As a rule, however, systems that allow partial cumulation attempt to relegate most industrial art to special design laws despite general principles of copyright law that prohibit legal discrimination on the basis of artistic merit. ${ }^{131}$

Three options-cumulation, noncumulation and partial cumulation-have thus continued to exist in the Berne Union's imtellectual property law system after the Brussels Conference of 1948. Some countries have shifted allegiance over the course of time, notably the United Kingdom ${ }^{132}$ and the Benelux group. ${ }^{133}$ The choices among these op-

129. See supra text accompanying notes 73-78. The unity of art doctrine thus routinely permits long-term protection of aesthetic designs, with moral rights and without any formalities whatsoever.

130. See infra text accompanying notes 200-26, 356-412.

131. Pérot-Morel, Pavia Conference, supra note 87, at 385-86; Pérot-Morel, supra note 126, at 141-42. The system in the Federal Republic of Germany is the prototypical regime of partial cumulation within the European Community. See generally Reichman, After the Copyright Act, supra note 65, at 293-97 (Benelux system), 336-40 (Federal Republic of Germany).

132. The situation in the United Kingdom is atypical, and citations to its law slould be used with caution. Prior to 1968, the United Kingdon adhered to a systen of noncumulation by express preference of the Copyright Act of 1911. This aligned thc United Kingdon with Italy's position, except that the United Kingdom adopted a purpose or destination test that tended to exclude designs reproduced in nore than 50 smgle articles from copyright protection. Excluded designs were protectible, if at all, under the Registered Designs Act of 1949 or its predecessors, which follow the patent law paradigm. Cornish, Cumulative Protection for Industrial Designs, 8 U. BRIT. Colum. L. Rev. 219, 226-30 (1973); Wallace, Protection for Designs in the United Kingdom, 22 BULl. COPYRIGHT Soc'y 437, 437-39 (1975). The United Kingdon's Copyright Act of 1956 retained the anticumulationist stance of prior law and provided for a "terminable copyright," i.e., designs copyrightable as artistic works when applied to more than 50 single articles forfeited protection with respect to these articles only. Wallace, supra, at 440 . In 1968, a hurriedly drafted oneclause bill, imtroduced by a Private Member of Parhaunent with some government support, succeeded in amending section 10 of the Copyright Act of 1956 "so as to postpone the loss of copyright in Inass-produced articles for 15 years from the datc in whicl the articles were first warketed." Wallace, supra, at 439-40; see Cormish, supra, at 230-33.

The desired effect of the 1968 "bill," known as the Design Copyright Act of 1968, was to install a regime of partial cumulation for a period of 15 years, because even a design registerable under the Registered Designs Act of 1949 could receive copyright protection for 15 years when 
tions made by different countries reflect more than domestic selfinterest; they also reflect fundamental differences of principle concernmg both the nature of art and the proper limits of protection for intellectual property, which differences are exacerbated by the hybrid nature of mdustrial art. ${ }^{134}$ Until they are resolved or tempered by compromise, no international system of design protection can fulfill its goals, despite contmumg efforts at harmonization and reform. ${ }^{135}$

\section{Options for the United States.}

International preoccupation with special regimes of design protection since 1958 should not obscure the importance of the Berne Union's

embodied in a useful article. The "bill," however, said nothing about excluding functionally dictated designs from its sweep. From 1972 on, English courts began to afford copyright protection to nonartistic, purely technical designs, originally deposited im two-dimensional form and later embodied in three-dimensional models, on analogy to dolls made from cartoon eharacters. "No matter how mundane or functional" the design, it was now copyrightable "regardless of the existence, or non-existence, of patent, design patent or other industrial property rights." Stevenson, Protection for Industrial Designs under the British Copyright Act of 1956, 8 A.P.L.A. Q.J. 369,369 (1980); see Baillie, Design Copyright Protection in the United Kingdom, 15 1NT'L LAw. $92-93$ (1981). Meanwhile, a three-dimensional aesthetic design for a suite of furniture, not deposited origimally in two-dimensional form, was denied copyright protection because it was not a "work of artistic craftsmanship" within the meaning of the 1956 Act. Bloon, Lost in the Bronx, 22 BULL. CopYRIGHT SOC'Y 199-207 (1975); see also RUSSELL-ClaRK ON COPYRIGHT IN INDUSTRIAL DESIONS 78, 142-44, 148-52 (M. Fysh èd. 1974).

In the United Kingdom, the lines between copyright law, patent law, sui generis design law and utility models (not officially protected) have thus become blurred and, indeed, hopelessly confused as the result of "a series of mistakes and oversights on the part of legislative draftsmen." Stevenson, supra, at 369. An inquiry by a parhiamentary commission left the situation more confused than before. See Copyright and Designs Law-Report of the Committee to ConSider the LaW ON COPYRIGHT aNd Desions (The Whitford Report) Cmnd. 6732 (1977); Dworkin, The Whitford Commiltee on Copyright and Designs Law, 40 MoD. L. Rev. 685, 685-89, 694-96 (1977). Most recently, a government Green Paper denounced the anonaly of protecting "functional designs without aesthetic merit" for life plus 50 years, simply because the designs were derived froin two-dimensional drawings, while protecting three-dimensional aesthetic designs for only 15 years in the same copyright law and registered designs for 20 years under the Rcgistered Designs Act of 1949. Reform of the law Relating to Copyright, Desions, and Performers' Protection-A Consultative Document 4-8 Cmnd. 8302 (1981) [hereinafter cited as REFORM OF THE LAW (UK)]; see Tarnofsky, Reform of United Kingdom Copyright, 18 COPYRuGHT 367, 367-68 (1982)(stresses harmful effects of protecting foreign products on domestic market under current regime without corresponding protection for English products elsewhere in Berne Union). For these reasons, the situation in the United Kingdom is not used as a basic point of reference for this article.

133. See infra text acconipanying notes 609-11. See generally Reichman, After the Copyright $A c t$, supra note 65, at 283-97.

134. Perot-Morel, Pavia Conference, supra note 87, at 381; see also Reichman, After the Copyright Act, supra note 65, at 367-73.

135. Pérot-Morel, supra note 2, at 61; Cohen Jehoram, supra note 125, at 240. For recent proposals, see, for example, Haertel, Harmonisation des Législations des Pays des Marché Commun ou relance d'un droit communautaire en matière de dessins et modeles, GRENOBLE SYMPOSIUM, supra note 2, at 31-39; Gaubiac, supra note 48 , at $64-70$. 
decision at the Brussels Conference in 1948 to legitimate applied art. ${ }^{136}$ This foundation was further consolidated at subsequent revision conferences and through negotiations of inter-governmental committees, which narrowed the distance between the Berne and the Geneva Conventions. ${ }^{137}$ With the 1954 decision in Mazer $v$. Stein, the United States Copyright Office, under the leadership of Arthur Fisher, persuaded the United States, through its Supreme Court, to join an international consensus favoring recognition of applied art as copyrightable subject matter. ${ }^{138}$

Mazer v. Stein, however, opened the very question of cumulation left unresolved at the Brussels Conference of 1948. The Court acknowledged in dictum that the availability of protection for ornamental designs under the patent law should not necessarily bar the copyrightability of applied art. Yet the United States possessed no sui generis design law like those enacted abroad; ${ }^{139}$ its design patent law had come, through judicial construction, to protect very few ornainental designs smce the 1920's. ${ }^{140}$ The significance of Mazer was thus unclear. The decision could have been construed to put the United States on a number of paths: first, broadly protecting industrial art under copyright law; ${ }^{141}$ second, permitting only narrow access to copyright law, ${ }^{142}$ with state unfair competition law a possible alternative for

136. Duchemin, supra note 2 , at 10-13.

137. See supra notes 26-27, 98-104 and accompanying text.

138. Design Protection Hearings 1960, supra note 115, at 63 (testimony of Arthur Fisher); Kaminstein, Fisher Memorial, supra note 26, at xiii; Ringer, supra note 1, at 1061 (Ringer speaks of adjustments to domestic law under aegis of "advocates of international copyright protection"). Kaminstein and Ringer, respectively, succeeded Fisher as Register of Copyrights.

139. See supra note 21; see also Note, supra note 21, at 865 (listing 71 design bills not passed by Congress simce 1914).

140. See Derenberg, supra note 17, at $693-706$ (discussing a ten-year survey of design patent litigation, which found that more than three times as many design patents were adjudged invalid than were found to be valid); see also Nimetz, supra note 18, at 83 ("the hostility of the courts to patents in general and to design patents in particular makes a design patent a most uncertain form of protection").

141. See 1 M. NIMMER, supra note 1, § 2.08[B], at 2-88, 2-96.3; infra note 347 and accompanying text. The following language from the opinion supports this broad reading: "They [works of art] must be origimal, that is, the author's tangible expression of his ideas . . . Such expression, whether meticulously delineating the model or mental image or conveying the meanimg by modernistic form or color, is copyrightable." Mazer v. Stem, 347 U.S. 201, 214 (1954)(citing Bleistein v. Donaldson Lithographing Co., 188 U.S. 239 (1903)).

142. See, for example, the separate opinion of Justices Douglas and Black who questioned whether the useful articles allowed to register for copyright protection at the time of Mazer were "writings" of authors in the constitutional sense. Mazer v. Stem, 347 U.S. 201, 220-21 (1954)(separate opimion of Douglas, J.); see also B. KAPLAN, AN UNHURRIED VIEW OF COPYRIGHT 55 (1967); Demicola, supra note 20, at 722-27, 741; Comment, Copyright Protection for Mass-Produced, Commercial Products: A Review of the Developments Following Mazer v. Stein, 38 U. CHI. L. REv. 807, 822-23 (1971) [hereimafter cited as Chicago Critics]. The view that ornamental designs should not 
noncopyrightable designs; ${ }^{143}$ third, permitting similarly narrow access to copyright law, while protecting the bulk of ornamental designs in a new, sui generis design law. ${ }^{144}$

To understand the evolution of design protection in the United States, ${ }^{145}$ one must first determine whether the United States adopted one of the positions taken by the Berne Union countries-cumulation, noncunnulation, or partial cumulation-after Mazer. ${ }^{146}$ This in turn focuses attention on differences between the "copyright approach" and the "patent approach" to industrial art, 147 and on the extent to which

obtain any form of protection, in or out of copyright law, is shared by no country within the European Community and by few, if any, countries within the OECD group; it is also inconsistent with the views of the CMEA countries. See supra notes 111-18 and accompanying text.

143. Justice Douglas, whose doubts about the wisdoin of Mazer were expressed in a separate opinion, see Mazer v. Stein, 347 U.S. 201, 220-21 (1954)(Douglas, J.), later caine to regard the misappropriation theory of unfair competition law as a possible solution despite the preemption doctrine he announced in the Sears-Compco cases of 1964. See Nimmer, A Comment on the Douglas Dissent in Lee v. Runge, 19 Bull. CopYright Soc'y 68, 71 (1971); infra notes 420-24 and accompanying text. Compare Reichman, After the Copyright Act, supra note 65, at 288-93 (Netherlands courts in this period used unfair coinpetition law to rescue designs excluded from copyright law).

144. In fact, the Copyright Office intended the legitimation of applied art in the United States to be merely the first step in a program to establish an American regime of sui generis design protection in keeping with the spirit of reform emerging abroad. This task was shouldered with "endless effort" by Arthur Fisher, the Register of Copyrights at the tine Mazer $v$. Stein was decided. Kaminstein, Fisher Memorial, supra note 26, at xiii-xiv; see also Derenberg, supra note 17, at 705 .

145. A bibliograpliy of the literature on this question lias been prepared by the Copyright Office and published by the Library of Congress. See B. Ringer, Bibliography on DEsion Protection (1955); Supplement to Blbliography on Desion Protection (W. Strauss and B. Ringer eds. 1959); K.M. MOTT, BIBLIOORAPHY ON DESIGN PROTECTION-SUPPLEMENT (1976).

146. This would be the logical point of departure regardless of the status of special design legislation, since the United States Design Patent Law of 1842 remained in force after the recognition of applicd art in Mazer. See supra note 18 and accoinpanying text.

147. Under the "copyright approach," the basic criterion for protection should be originality in the sense of independent creation; in foreign literature, the term "subjective novelty" is frequently used instcad of "originality in the copyright sense." The work seeking protection should be the designer's own work and not something he las copied. Wallace, supra note 132, at 437. Under the "patent approacli" to design protection, standards of objective novelty must be satisfied. The designer of an original form inay nonetheless lose his exclusive rights if he was anticipated by a very similar design, while the proprietor of a protected design inay be able to prevent anyone else froin marketing articles bearing the same or a very similar design. Id.; Ljunginan, The Scandinavian Approach in Design Protection-Aims and Outcomes-In Comparison with the New Benelux Legislation, reprinted in AMSTERDAM SYMPOsIUM, supra note 21, at 119.

The terms "copyright approach" and "patent approacly" inust be used witls caution, as the distinction is seldoin as clear-cut in practice as the prototypes suggest. The terns do reflect an underlying conflict of attitudes that is responsible for many of the difficulties and misunderstandings encountered in this field:

Normally the paths of patent inen and copyright inen do not cross. It is only on those rare occasions when the question of design protection is under consideration that the clash of minds occurs. Each contestant knows instinctively that the primciples whicl he 
unfair competition law accommodates ornamental designs otherwise denied protection.

This article concentrates on the copyright approach to industrial art in the United States, from the Mazer decision of 1954 to the General Revision of Copyright Law enacted in 1976. ${ }^{148}$ The subject can be subdivided into two periods. During the first, from 1954 to 1969, the Copyright Office tried to limit the access of industrial art to protection afforded by the Copyright Act of 1909, while pressing Congress for prompt enactment of a sui generis design law intended to resolve many of the problems known to exist abroad. ${ }^{149}$ In the second period, from 1969 to 1976, the Copyright Office sought to limit the breaches in defenses erected earher, while Congress delayed enactment of both the general revision of copyright law and the special design law incorporated within it. 150

Since 1954, the United States has experimented with each of the basic positions im foreign law and found all of them unsatisfactory. ${ }^{151}$ Similarities between interim models emerging in the federal appellate courts and the primary models in foreign law help to account for what otherwise appear to be a series of actions and reactions in domestic law with no clear logic of their own. The resultimg contradictions have spht United States Courts of Appeals into opposing camps not unlike those found within the European Community and the Berne Union as a whole. ${ }^{152}$ Courts can more effectively address difficulties created by the

\footnotetext{
learnt in his apprentice days and has practised since, are the right ones. It is what the Americans expressively call a "gut reaction."

Wallace, supra note 50, at 39; see supra note 89.

148. Copyright Act of 1976, 90 Stat. 2541 (codified at 17 U.S.C. $\$ \$ 101-810$ (1982): $\S 101$ ("Pictorial, graphic, and sculptural works," "useful article"), $\$ 102$ (subject matter of copyright), $\S 113$ (scope of exclusive rights in pictorial, graphic, and sculptural works), $\$ 301$ (preemption with respect to other laws), $\S 410$ (registration and issuance of certificate), $\S 702$ (Copyright Office regulations).

149. "[I]t seems it is much better and more appropriate not to deal with these problems merely as a phase of copyright law, but by a sui generis short-term law restimg on its own bottom. I think that this is the general view in the world." Design Protection Hearings 1960, supra note 115, at 6364 (testimony and statement of Arthur Fisher, Register of Copyrights).

150. A second article by the author deals with the period from 1976 to the present, in which the Copyright Office and the courts have tried to administer a set of cryptic instructions handed down by Congress-without a design law-in the Copyright Act of 1976. See generally Reichman, After the Copyright Act, supra note 65; see also infra text accompanying notes 634-47.

151. The present article deals mainly with noncumulation. Phases of cumulation and partial cumulation are the primary focus of Reichman, After the Copyright Act, supra note 65.

152. The division is as follows: The Second Circuit is following a regime of partial cumulation. See Durham Indus. v. Tomy Corp., 630 F.2d 905, 909-11 (2d Cir. 1980); Kieselstein-Cord v. Accessories by Pearl, 632 F.2d 989, 993-94 (2d Cir. 1980); L. Batlin \& Sons v. Snyder, 536 F.2d 486, 490-92 (2d Cir.)(cn banc), cert. denied, 429 U.S. 857 (1976). The District of Columbia and Eleventh Circuits are following a regime of noncumulation. See Norris Indus. v. ITT Corp., 696 F.2d 918, 922-24 (11th Cir. 1983); Esquire, Inc. v. Ringer, 591 F.2d 796, 800-04 (D.C. Cir. 1978).
} 
failure of the 1976 Copyright Act to adopt a coherent position with regard to industrial designs ${ }^{153}$ by comparing current problems in the United States with those already faced abroad. ${ }^{154}$ European observers should benefit from this comparative analysis, ${ }^{155}$ which illuninates as well the inerits and deinerits of proposals concerning the enhancement of trade through nore satisfactory regulation of design protection at the international level. ${ }^{156}$

\section{Evolution OF THE COPYRIGHT APPROACH FROM MAZER $\nu$. STEIN TO THE GENERAL REvision of 1976}

\section{A. Rise and Fall of the First Noncumulationist Model.}

1. Art in the Historical and Ordinary Sense. The United States judiciary, which had resisted the implenentation of Regulation Section 202.8 between 1948 and 1953, ${ }^{157}$ was prepared initially to give Mazer $\nu$. Stein a very broad reading. In 1955 , for exanuple, the United States District Court for the Southern District of New York upheld the protectibility of a costume jewelry necklace, declaring that "a commonplace fashion accessory," although "not an expression of 'pure' or 'fine' art," could nonetheless be copyrighted as a work of art. ${ }^{158}$ In the same year, the United States Court of Appeals for the Second Circuit upheld

The Ninth Circuit, although excluding nontraditional utilitarian designs from copyright law, has expanded the federal law of unfair competition to protect the excluded designs. See Fabrica, Inc. v. El Dorado Corp., 697 F.2d 890, 893-94 (9th Cir. 1983). See generally Reichman, After the Copyright Act, supra note 65, at 312-86.

153. Although the term "industrial design" continues to be used in the literature and the case law, it is less satisfactory than the terms "designs of useful articles" or "ornamental designs of useful articles." See Design Protection Hearings 1960, supra note 115, at 56 (statement of Arthur Fisher). The term "industrial designs" includes nonornamental, purely technical designs laving no eye-appeal whatsoever. Use of the term "industrial designs" also accentuates the tendency of courts and writers to treat the objects of protection as artifacts rather than "works" enbodied in a inaterial support. See 17 U.S.C. § 102(a) (1982)("works of authorship").

154. See Reichnian, After the Copyright Act, supra note 65 at 365-86.

155. The different models operating separately under foreign law have, in the United States, interacted with one another within a single field of legal operations removed froin soine of the historical factors influencing developinents abroad. The evolution of the copyright approach in the United States thus sleds new light on the disruptive effects that designs of useful articles have been producing within the world's intellectual property law systein as a whole.

156. See Reichman, After the Copyright Act, supra note 65, at 365-86; see also J. HeSKETT, supra note 5, at 184, 199-200 (increased role of design in international trade leads governments to stimulate design innovation for export purposes).

157. See supra text accompanying notes 28-29.

158. Trifari, Krussinan \& Fislel v. Charel Co., 134 F. Supp. 551, 553 (S.D.N.Y. 1955); see also Trifari, Krussinan \& Fislel v. B. Steinberg-Keslo Co., 144 F. Supp. 577, 579 (S.D.N.Y. 1956); Hollywood Jewelry Co. v Dushkin, 136 F. Supp. 738, 739 (S.D.N.Y. 1955).

The claracterization of the object as "commonplace" would have excluded it from protection under the special design law soon to be proposed by the Register of Copyrights. See § 2(a), S. 2075 (O'Mahoney-Wiley-Hart Bill), 86th Cong., Ist Sess. May 28, 1959, refining H.R. 8873 (Willis 
the copyrightability of a doll modeled after a chimpanzee then appearmg on television. ${ }^{159}$

Continued decisions in this vein could have led to a United States version of the French unity of art thesis. Under the 1909 Act, this meant that copyrighted designs would obtain protection for a nuaxiinum period of 56 years, and an average period of 28 years, ${ }^{160}$ without moral rights, ${ }^{161}$ on condition that strict formal prerequisites had been satisfied. Even the broadest reading of Mazer v. Stein could not have freed applied art in the United States from the requirements of publication with notice, and of registration and deposit ${ }^{162}$ prohibited under the Berne Convention, ${ }^{163}$ nor could it have accorded such works either the noral rights or the long duration routinely available under the Convention. ${ }^{164}$ For these reasons, the paradigm underlynig Mazer seens closer in spirit to the special design bill the Copyright Office was

Bill), 85th Cong., 1st Sess. July 23, 1957 (copy on file at the Center for Research Libraries, Chicago, Illinois).

159. Rushton v. Vitale, 218 F.2d 434, 436 (2d Cir. 1955) (citing Mazer v. Stein, 347 U.S. 201, 214 (1954)). Both this case and the costume jewelry cases, supra note 158, were decided under the regulation upheld in Mazer, 37 C.F.R. \& 202.8(a) (1949). In 1958, the Second Circuit upheld the registration of costume jewelry earrings, apparently under the same 1949 regulation, in Boucher v. Du Boyes, Inc., 253 F.2d 948, 949 (2d Cir.), cert. denied, 357 U.S. 936 (1958). The decision in Mazer was said to be "a coinplete answer" to a claim that jewelry was noncopyrightable subject matter.

160. Copyright Act of $1909, \S 24,35$ Stat. 1075, 1080-81. The renewal copyright, valid for a second period of 28 years, was conditioned upon timely application at the Copyright Office within one year prior to the expiration of the original copyright. A. LATMAN, THE COPYRIGHT Law: Howeli's Copyright LaW REvised AND THE 1976 ACT 72-73 (5th ed. 1979). In 1959, about eighty-five percent of the copyrights registered under the 1909 Act were not being renewed. Ringer with Culp, Renewal of Copyright, reprinted in 1 STUDIES ON COPYRIGHT 503, 583 (1963).

161. Among the rights not granted under either the 1909 or the 1976 Copyright Acts are the "moral rights" (droit moral) recognized under the Berne Union system, which are normally perpetual in duration, malienable, and intended to safeguard the author's artistic reputation rather than the proprietary aspect of the copyright. See 2 M. NiMmer, supra note 1, \& 8.21, at 8-247.

162. Formal prerequisites under the 1909 Act included publication with notice on pain of technical forfeiture; actual registration as a prerequisite for an infringement action; deposit of "the best edition . . . then published" ( $\$ 13$ )(not usually a cause of invalidation). Works intended for exhibition might qualify for registration in unpublished form. See Copyright Act of 1909, supra note 9, \$§ 5, 10-14, 19, 24-25; A. LATMAN, supra note 160, at 110-11, 152-57; see also Henn, Cassandra Considers Copyright, 25 BULl. CoPYRIGHT Soc’y 453, 457, 465, 471 (1978)(criticizing 1976 Act).

163. Article 5(2), Paris Revision, supra note 1 (repeating article 4(2) of 1948 Brussels Revision), provides that "The enjoyment and the exercise of these rights shall not be subject to any formality."

164. On moral rights, see A. DieTZ, supra note 13, at 66-78. The period of protection in the Federal Republic of Gernany has been extended to life plus seventy years, twenty years more than the Berne Union norm. A. DiETz, supra note 13, at 164. Since the 1948 coinpromise, the Berne Union members may, and do, derogate from sone convention norms with regard to applied art. See Fox, Copyright and Industrial Designs in Canada, 5 BULl. Copyrught Soc'y 117, 138 (1958). 
about to sponsor ${ }^{165}$ than to the copyright paradigm accepted by the Berne Union. 166

The Copyright Office, however, nitended to move toward the Berne Union's copyright paradigm in its program for a general revision of the copyright law, begun in 1955.167 In 1953, a committee of experts had begun drafting a modern design bill for the United States. Although Mazer's legitimation of applied art was largely due to Copyright Office intervention, ${ }^{168}$ Register Fisher soon gave the committee his support. ${ }^{169}$ Viewing this project as an opportunity to forestall the problems of overprotection associated with the copyright approach in France and Belgium, he endorsed the policy that designs of useful articles should in principle seek protection exclusively fron the sui generis regime under study. ${ }^{170}$

Register Fisher's decision rendered particularly delicate the task of managing the category of apphed art in the short run. The Copyright Office optimistically assumed that a new design bill could be enacted before the legislative phase of the general revision of copyright law. ${ }^{171}$ Nevertheless, interim measures were needed to prevent the acquisition of rights and the accumulation of expansionist precedents that would

165. See infra text accompanying notes 247-56.

166. See Z.O. AlGARDI, supra note 61, at 102 (recognizes affinities between 1909 Act (USA) and special design laws); see also Ringer, supra note 1, at 1062.

167. Register's RePort 1961, supra note 45, at ix-x (Preface); Nimmer, Implications of the Prospective Revisions of the Berne Convention and the United States Copyright Law, 19 STAN. L. Rev. 499, 499-502 (1967). General revision bills tracked the Berne model as far as legislatively feasible bnt not far enough to qualify for membership in the Berne Union. See Henn, supra note 162 , at $457,465,471$; supra note 163 .

168. See supra text accompanying notes $30-32$.

169. See infra text accompanying notes 286-87. Giles S. Rich, now a judge on the United States Court of Appeals for the Federal Circuit, became chairman of the Coordimating Committee on Designs, set up after Congress decided not to deal with ornamental designs in the patent law reforms of 1952. The Committee proposed the Willis Bill, H.R. 8873, supra note 158, imtroduced in the 85th Congress in 1957 and subsequently revised and promoted by a National Committce for Effective Design Legislation. The sequel to the Willis Bill was the O'Mahoney-Wiley-Hart Bill, S. 2075, supra note 158, presented to the 86th Congress in 1959. Latman, A Proposal for Effective Design Legislation: S. 2075 Examined, 6 Bull. Copyrught Soc'Y 279, 279-80 (1959). Judge Rich was assisted by advisers from the Patent Office and the Copyright Office, includimg the future Register, Barbara Ringer. See Design Protection Hearings 1960, supra note 115, at 47-54 (testinony of Judge Rich); Hearings on H.R. 2223 Before the House Subcomm. on Courts, Civil Liberties, and the Administration of Justice of the Comm. on the Judiciary, 94th Cong., Ist Sess. 992 (1975) (testimony of Alan Latman) [hereinafter cited as Hearings 1975]. Professor Latman was counsel to the National Committee for Effective Design Legislation. Id.

170. See supra note 149; infra notes 286-87 and accompanying text; Design Protection Hearings 1960, supra note 115, at 66 (testimony of Arthur Fisher).

171. REGISTER's DRAFT REPORT 1975, supra note 36, at 7; see also Hearings 1975, supra note 169 , at 1855 (testimony of Barbara Ringer). 
be difficult to eliminate once new legislation was enacted. ${ }^{172}$ The first regulation issued after Mazer, in 1956, therefore signalled caution to the courts in section 202.10(c):

When the shape of an article is dictated by, or is necessarily responsive to, the requirements of its utilitarian function, its shape, though umque and attractive, cannot qualify it as a work of art. If the sole intrinsic function of an article is its utility, the fact that it is unique and attractively shaped will not qualify it as a work of art. However, where the object is clearly a work of art in itself, the fact that it is also a useful article will not preclude its registration. ${ }^{173}$

This regulation seems to have exerted a temporary restraining influence on the courts. ${ }^{174}$ The United States District Court for the Southern District of New York, which had allowed a commonplace design to be copyrighted im 1955, upheld the denial of registration to a stylized, modernistic watch face in 1957 in Vacheron \& Constantin-Le Coultre Watches v. Benrus Watch Co. ${ }^{175}$ The district court applied the "colloquial rather than philosophical" definition of a "work of art" that it found in the 1956 regulation.176 Apparently influenced by the "sole intrinsic function" language of section 202.10(c), 177 the court drew the line of protectibility at what it understood to be "works of artistic craftsmanship." 178

172. Design Protection Hearings 1960, supra note 115, at 66 (testimony of Arthur Fisher); Design Protection Hearings 1961, supra note 21, at 86 (testimony of Giles Rich) ("the late Register of Copyrights, Arthur Fisher, has often described the situation as one where he was holding his foot on the door to keep this flood of useful articles out of the Copyright Office until such time as we could get a proper kind of law to take care of it").

173. 21 Fed. Reg. 6024 (1956)(emphasis added)(repealed, 43 Fed. Reg. 966 (1978), 37 C.F.R. $966(1978))$.

174. The view that the Copyright Office's regulations were continually liberalized after Mazer v. Stein is correct with reference to the period following this 1956 regulation, which attempted to cut back on the broad reading of Mazer $v$. Stein. The view that courts are inclined to accept as a work of art any work "which by the most generous standard may arguably be said to evince creativity" did not apply to designs of useful articles in the period 1956-1958; the extent to which it apphes in the Second Circuit after 1976 is debatable. See 1 M. NimMER, supra note 1, \$2.08[B], at 2-84. But see Reichman, After the Copyright Act, supra note 65, at 297-350 (partial cumulation in the Second Circuit).

175. 155 F. Supp. 932, 934-35 (S.D.N.Y. 1957), modified, 260 F.2d 637 (2d Cir. 1958).

176. 155 F. Supp. at 934.

177. Plaintiff had argued unsuccessfully that utility could not be the "sole intrinsic function" of its design because the artistic effect of the design made it difficult to tell time from the face of the watch. Vacheron, 155 F. Supp. at 934-35.

178. The District Court proceeded to uphold a design patent on the same watch face, "every element" of which had been "anticipated by the prior art." Validity was premised on the rearrangement of old elements that "has the necessary beauty and originality born of the inventive faculty." Id. at 935.

On appeal, Chief Judge Clark, in dissent, reminded the district court that "to my knowledge, our court has never sustained a design patent challenged for lack of novelty." Vacheron \& Constantin-Le Coultre Watches v. Benrus Watch Co., 260 F.2d 637, 643 (2d Cir. 1958)(Clark, C.J., 
Similarly, in 1958, the United States Court of Appeals for the District of Columbia Circuit upheld the denial of copyrightability to a "cardboard star with a circular center bearing the photograph of an entertainer." 179 The court expressly endorsed the Register's contention that "a thing is a work of art . . . if it appears to be within the historical and ordinary conception of the term art." 180 Rigorously applied, this rationale could have overruled previous decisions validating dolls and even costume jewelry as copyrightable works of art.

In retrospect, however, it seeins clear that the 1956 regulation could not have sustained for very long the restrictive effects desired by the Copyright Office. No nrodern designer ignores the function of the article he shapes. Accordingly, language in the first sentence of section 202.10 (c) that appeared to exclude from protection all articles whose shapes were "necessarily responsive to" their utilitarian functions was so broad that it sidestepped the Supreme Court's strictures against a "narrow or rigid conception of art."181 The final sentence of the regulation, which permitted copyrightability of an object clearly a work of art in itself, said either too little or too nuch. If this sentence meant that the Copyright Office was to make an assessment of the artistic

dissenting). For Judge Clark, however, these "highly ornamented watches" were copyrightable under Mazer v. Stein and its immediate progeny. Id. at 644 .

179. Bailie v. Fisher, 258 F.2d 425, 426 (D.C. Cir. 1958)(per curiam). In 1960, after an amendment to the regulations, the Register did issue a certificate for "multipoimted spherical foil and plastic stars" not challenged as works of art. Elekes v. Bradford Novelty Co., 183 F. Supp. 730, 731-33 (D. Mass. 1960); See 1 M. NiMMER, supra note 1, $\S 2.08[B]$, at 2-85. In view of the separability test in use at least as early as 1958, and officially adopted in 1959, this was less contradictory than it looks. See infra text accompanying notes 197-201.

180. Bailie, 258 F.2d at 426, (citing Rosenthal v. Stem, 205 F.2d 633, 635 (9th Cir. 1953)(“A cardboard star which stands because of folded flaps does not fall within that conception.")). Professor Latman regards this case as illustrating insufficient "originality or creativity." Latman, supra note 9, at 280. This was the direction that United States case law would vigorously pursue from 1976 on. See Reichman, After the Copyright Act, supra note 65, at 308-21.

181. See supra text accompanying note 173. The notion that the "shape of an article . . dictated by . . the requirements of its utilitarian function," 21 Fed. Reg. 6024 (1956)(repealed, 43 Fed. Reg. 966 (1978), 37 C.F.R. 966 (1978)), should not be protectible in copyright law is accepted nearly everywhere. The obvious reason is not that such designs cannot be works of art, but rather that their protection would circumvent the strict requirements of the patent law. See Baker v. Selden, 101 U.S. 99, 102 (1880); Pérot-Morel, Designs and Patents, AMSTERdam Symposium, supra note 69, at 67-69. But see supra note 132 (discussing the United Kingdom).

Nevertheless, the notion that "the shape of an article . . [ [that] is necessarily responsive to . . the requirements of its utilitarian function," 21 Fed. Reg. 6024 (1956)(repealed, 43 Fed. Reg. 966 (1978), 37 C.F.R. 966 (1978)) cannot be copyrightable is a formula for the exclusion of most industrial art, which im a broad sense is "necessarily responsive to" utilitarian functions by definition. The 1956 regulation thus restated the traditional antinomy of art versus utility. It also evoked the "aesthetic surplus" doctrime that developed in Germany around 1907. See Reimer, supra note 91, at 40-42 ("aesthetic surplus" test stressed that aesthetic elements added to functional aspects must attain level of work of art). See generally Reichman, After the Copyright Act, supra note 65 , at $337-38$. 
value of designs seeking registration, it seemed to validate considerations of merit that Bleistein prohibited; this would necessarily beg the question of the Register's authority to make such determinations. ${ }^{182}$ This language may also have signified an administrative preference for a regime of partial cumulation. ${ }^{183}$

When Vacheron reached the United States Court of Appeals for the Second Circuit in 1958, ${ }^{184}$ these issues proved troublesome. Chief Judge Clark, dissenting, attacked the imconsistency of the Copyright Office in permitting registration of ordmary costume jewelry under the authority of Mazer but denying registration to the highly artistic watchface design in Vacheron. ${ }^{185} \mathrm{He}$ also flatly denied the authority of the Copyright Office to act as if it possessed "judicial or discretionary functions such as has the Cominissioner of Patents."186 Judge Hand, writimg for a weak majority, ${ }^{187}$ avoided resolving the question of authority to judge art. ${ }^{188}$

182. 188 U.S. 239 (1903). Register Fisher claimed that the Copyright Office did in fact possess such authority. Fisher Address, supra note 107, at 205; see also Berger, Authority of the Register of Copyrights to Reject Applications for Registration, reprinted in 1 STUDIES ON COPYRIGHT 393-408 (1963).

183. "Clearly a work of art in itself" implies that differences in the degree of creative content or of artistic value may become critical determinants of copyrightability. Under regimes of partial cumulation, courts are willing, to a greater or lesser extent, to undertake such an assessment of crcativc content in individual cases. See supra note 131 and accompanying text. That the United States Copyright Office preferred and, between 1955 and 1976, often covertly practiced a regime of partial cumulation is one of the theses of this study. See infra text accoinpanying notes 533-56, 578-633.

184. Vacheron \& Constantin-Le Coultre Watches v. Benrus Watch Co., 260 F.2d 637 (2d Cir. 1958), modifying 155 F. Supp. 932 (S.D.N.Y. 1957).

185. 260 F.2d 642, 644 (2d Cir. 1958)(Clark, C.J., dissenting); see supra note 178. This inconsistency resulted in part because the decisions admitting costume jewelry under Mazer predated the Copyright Office's choice of a line of defense. If Mazer validated costume jewelry, then denial of copyrightability to a highly artistic watch-face design seemed inconsistent. If, however, the 1956 regulation validly narrowed Mazer, and the Copyright Office intended to impose a rather high threshold for ornamental designs thereafter, then denial of copyrightability was consistent with the regulation and part of a campaign to eliminate designs embodied in useful articles froun copyright law.

The Register's intention to elevate the standard for copyrightability under his 1956 test to a very high threshold appears from the demial of registration to a design so exceptional that the lower court found it had met even the test of nonobviousness under the design patent statute. See supra note 178 and accompanying text; infra notes 578-633 and accoinpanying text.

186. Vacheron, 260 F.2d at $644-45$ (Clark, C.J., dissenting).

187. Judge Lumbard concurred on narrow grounds. Id. at 642 (Lumbard, J., concurring).

188. "It is true that "works of art' is a loose phrase whose perimeter is lard to define," he conceded. "Nevertheless, the decision here did not demand the exercise of a discretion . . . conclusive with the Register," in view of the writ of mandamus that might lie in other cases. Vacher$o n, 260$ F.2d at 640 . This decision established that actual registration, rather than an application for registration without more, was a prerequisite for an infringement action under the 1909 Act. A. LATMAN, supra note 160, at 156. Section 411 of the 1976 Act now perimits an infringement action even where registration has been refused. Nova Stylings, Inc. v. Ladd, 695 F.2d 1179, 1181 
Earlier that year, however, the Court of Appeals for the District of Columbia Circuit lad determined in Bailie v. Fisher that the Copyright Act of 1909 established "a wide range of selection within which discretion must be exercised by the Register in determining what he has no power to accept."189 Because Bailie dealt specifically witl the scope of the 1956 regulation concerning applied art, the Register's authority extended by inference to determining when "the object is clearly a work of art in itself." 190 These cases laid the foundation for the conflict between the circuits that developed after Congress enacted the Copyright Act of 1976.191

The legality of the Register's criterion was open to question on other grounds as well. Regulation Section 202.10(c) appeared to inean that only "art in the historical and ordinary sense" was copyrightable, as the District of Columbia Circuit had declared in Bailie. ${ }^{192}$ Yet, in the "historical and ordinary sense," art and utility were antithetical by definition, a position the Copyright Office had inaintamed for forty years prior to 1949 . On this interpretation, the 1956 regulation implicitly resurrected the "dichotomy of . . . beauty and utility" that the Supreine Court liad expressly disapproved in Mazer. ${ }^{193}$

Until Vacheron in 1958, section 202.10(c) seemed capable of "holding the line" of copyrightability against designs of useful articles that practitioners were beginning to register under the authority of Mazer. ${ }^{194}$ After Vacheron, further insistence upon the test of aesthetic

(9th Cir. 1983). But the Copyright Act of 1976 may have increased the power of the Register by authorizing demal of registration upon a determination that a claim is invalid. Compare 17 U.S.C. $\S 410$ (b) (1982) with the implied authority claimed by Berger, supra note 182, at 398.

189. Bailie v. Fisher, 258 F.2d 425, 426 (D.C. Cir. 1958)(per curiam)(quoting Bouve v. Twentieth Century-Fox Film Corp., 122 F.2d 51, 53 (D.C. Cir. 1941)).

190. Regulation $\$ 202.10$ (c) (1956), supra text accompanying note 173 .

191. In a case arising after passage of the $1976 \mathrm{Act}$, the Second Circuit adopted a test not dissimilar from the one it undermined in Vacheron, which led to conflict with the District of Columbia Circuit once agam. See Kieselstein-Cord v. Accessories by Pearl, 632 F.2d 989 (2d Cir. 1980); supra note 152 and accompanying text; Reichman, After the Copyright Act, supra note 65, at $323-40$.

192. "A thing is a work of art if it appears to be within the historical and ordinary conception of the term art." Rosenthal v. Stein, 205 F.2d 633, 635 (9th Cir. 1953), quoted in Bailie v. Fisher, 258 F.2d 425, 426 (D.C. Cir. 1958)(per curiam), defended in Esquire, Inc. v. Ringer, 414 F. Supp. 939, 941 (D.D.C. 1976), rev'd on other grounds, 591 F.2d 796 (D.C. Cir. 1978), cert. denied, 440 U.S 908 (1979).

193. 347 U.S. 201, 218 (1954).

194. Once the practicing bar saw what Mazer lad to offer, the results staggered the Copyright Office. Some 3400 ornamental designs of useful articles were registered in 1959; in 1960 the figure rose to 5800, a $70 \%$ increase, "despite the Copyright Office taking a rather resistant, hold-the-line attitude with respect to . . how far we should extend the original copyright concept, say, into the lamp field." Design Protection Hearings 1960, supra note 115, at 58-59 (testimony of Arthur Fisher)(emphasis added). 
value implicit in the regulation was dangerous in view of Judge Clark's position. ${ }^{195}$ In order to minimize the risk of cumulation on the French model-between copyright law and a design law-the Office needed another criterion capable of excluding as many ornamental designs as possible without running afoul of Bleistein and without emptying Mazer of all meaning. ${ }^{196}$

To resolve this predicament the Copyright Office adopted in 1958 a "negative" interpretation of Mazer that sought to avoid the need to define a "work of art" for legal purposes.197 In "an effort to "implement' the Mazer decision," 198 the Office amended section $202.10(\mathrm{c})$ of its 1956 regulation by deleting clearly $a$ work of art in itself and inserting a test of artistic separability:

If the sole intrinsic function of an article is its utility, the fact that the article is unique and attractively shaped will not qualify it as a work of art. However, if the shape of a utilitarian article incorporates features, such as artistic sculpture, carving, or pictorial representation, which can be identified separately and are capable of existing independently as a work of art, such features will be eligible for registration. 199

195. Id. at 59 (testimony of Fisher, who feared that registrations of ornamental designs "might jump in a short time to many hundreds or thousands percent increase" absent restrictive measures of Copyright Office pending sui generis legislation that it was helping a committee of experts to draft).

196. See S. LADAS, supra note 2 , at 859.

197. Latman, supra note 9 , at 282 . The new test, to be introduced officially in 1959 , was in use at least as early as 1958. See Present Design Protection, supra note 48, at 139-40.

198. See RePORT OF THE COMM. ON THE JudicIARY, HousE OF REPRESENTATIVES, H.R. ReP. No. 1476, 94th Cong, 2d Sess. 54-55 (1976); 1 M. NiMMER, supra note 1, § 2.08[B], at 2-89.

199. 37 C.F.R. $\$ 202.10$ (c) (1959), as amended June 18, 1959 (revoked Jan. 1, 1978, 43 Fed. Reg. 966 (1978))(emphasis added). The entire regulation, which repeats the 1956 regulation in parts (a) and (b), is set forth below:

$\S 202.10$ Works of art (Class G).

(a) General. This class includes published or unpubhished works of artistic craftsmanship, insofar as their form but not their mechanical or utilitarian aspects are concerned, such as artistic jewelry, enamels, glassware, and tapestries, as well as works belonging to the fine arts, such as paintings, drawings and sculpture.

(b) In order to be acceptable as a work of art, the work must embody soine creative authorship in its delineation or form. The registrability of a work of art is not affected by the intention of the author as to the use of the work, the number of copies reproduced, or the fact that it appears on a textile inaterial or textile product. The potential availability of protection under the design patent law will not affect the registrability of a work of art, but a copyright claim in a patented design or in the drawings or photograpls in a patent apphication will not be registered after the patent has been issued.

(c) If the sole intrinsic function of an article is its utility, the fact that the article is umique and attractively shaped will not qualify it as a work of art. However, if the shape of a utilitarian article incorporates features, such as artistic sculpture, carving, or pictorial represeutation, which can be identified separately and are capable of existing independently as a work of art, such features will be ehgible for registration.

Compare the 1956 text, supra text accompanying note 173. 
The United States Copyright Office thus quietly embraced the "theory of dissociation" on which the Itahan regime of noncumulation is grounded. ${ }^{200}$ The American test of separability, imtroduced officially by the 1959 regulation, was an analogue of the Italian test of scindibilta adopted by the Itahan Copyright Law of 1941. ${ }^{201}$ This criterion, ${ }^{202}$ if apphed as in Italy, could have excluded even more industrial art from copyright law than the most rigorous test of aesthetic value. ${ }^{203}$

2. An Interim Theory of Dissociation. The unity of art theory asserts that industrial art is art; ${ }^{204}$ the theory of dissociation starts from the premise that industrial art is inextricably bound up with industrial products. ${ }^{205}$ Industrial products are protected by the laws of industrial

200. The criterion of separability arises from the so-called theory of dissociation, officially adopted in article 2(4) of the Italian Copyright Law of April 22, 1941 (No. 633), as amended by Decree No. 195, January 8, 1979, 2 CopYRIGHT LAWs, supra note 1, Italy itein 1. See M. FABIANI, supra note 96, at 18-30; F. PERRET, supra note 2, at 257-67.

201. See S. LADAS, supra note 2, at 842, 859; F. PERRET, supra note 2, at 263-64, n.254 \& n.258. In 1980, Franel and Gaubiac reconfirmed the use of the separability criterion by both Italy and the Umited States. Franel \& Gaubiac, supra note 123, at 16; see also Note, Toward a More Systematic Approach to the Protection of Art Applied to Industry, 6 BULL. CopYright Soc'y 287, 288 (1959)(this anonymous "note" on Italian law was condensed and translated froin DiRitro D'AUTORE 27-32 (Jan.-Mar. 1957)(it was published in its United States version about the time of the 1959 regulation) [hereinafter cited as Italian Law]; Waldheim, Don't Maim our Copyrights, 7 Bull. Copyright Soc'y 160, 161 (1960) [hereinafter cited as Waldheim, Don't Maim]; Waldheim, The "Anti-Maim" Rule-New Design Bill Shares Majority View Among Nations, 8 Bull. Copyright Soc'y 359 (1961) [heremafter cited as Waldheim, New Design Bill]. Italian writers prefer the term scindibiltz (separability) to the more theoretical notion of "dissociation." See M.A. Perot-Morel, supra note 2, at 99.

202. The criterion of separability adopted by the Copyright Office was quickly said to have "prevented copyright registration for purely functional designs (such as those of automobiles and refrigerators) which contain no separable pattern or ornamentation." Present Design Protection, supra note 48, at 139 (emphasis added). According to Professor Latinan, the Copyright Office now viewed Mazer as holding that "a most traditional art form-a human figure" was "not disqualified froin protection as a work of art' solely because it is enbodied in a functional article." Latman, supra note 9, at 278; see also REGISTER's DRAFT REPORT 1975, supra note 36, at 8. But see $1 \mathrm{M}$. NIMMER, supra uote $1, \S 2.08$ [B], at 2-96 (rejecting the notion that the figure and the base were ever separable).

The Copyright Office ignored the unity of art language in Justice Reed's opimion when it adopted the Italian criterion. See supra note 189. Professor Nimmer implies that the Copyright Office may have overstepped its authority in so doing. $1 \mathrm{M}$. NiMMER, supra note $1, \$ 2.08[\mathrm{~B}]$, at 289.

203. See infra notes $407-12$ and accompanying text. The Federal Republic of Germany imposes the inost stringent test of aesthetic value. Pérot-Morel, Pavia Conference, supra note 87, at 386; see Reichman, After the Copyright Act, supra note 65, at 337-400.

204. Z.O. AlgaRDI, supra note 61, at 66. According to Pouillet, the unification of industrial and artistic designs within a single regime of protection would encourage "the progrcss of art, that is, the progress of all that serves to einbellish our existence, to lend it charm, of all that responds to this aspiration for beauty, an ideal that inspires every human soul." E. PoullLET, DESSINS ET MODELES, supra note 61, at 54 (trans.).

205. G. Sena, I Diritti sulle INVenzionl E sui Modelli INDUStriali 450 (1976). 
property, which, in Italy, treat ornamental features of "shape, design, and color" as the subject matter of a special design law. ${ }^{206}$ The question then arises as to when elements of shape, design, and color used to einbellish an industrial product may be considered "works of art applied to industry" and therefore protectible under copyright law notwithstanding the existence of a special design law. The answer, according to the theory of dissociation, is that copyright protection will be accorded to a work that contains its own message and conserves its artistic value independently of the material support in which it is embodied. ${ }^{207}$

The theory of dissociation was carried to its logical conclusion in the last reform of relevant Italian law. Article 5 of the Italian Design Law of 1940 declared expressly that ornainental designs and models should not be protectible in copyright law. ${ }^{208}$ Article 2(4) of the Italian Copyright Law of 1941 codified the primciple of dissociation by granting protection to works of art applied to industry "if their artistic value is separable ${ }^{209}$ [scindibile] froin the industrial character of the product with which they are associated." 210 In keeping with the strictures of the design law, however, the protection afforded by copyright law is not

206. Id. Industrial models normally fall within the special legal regimes established for them by the Italian Design Law of 1940, supra note 96. Article 5 of this law establishes special protection for ornamental designs and models while Article 2 protects functional designs as utility models. Id.

207. "Dissociability occurs when the idea is expressed with such creative value as to contain its own value within itself, so that the [physical] matter constitutes only the vehicle necessary for the passage of the idea from the spirit of the creator to the spirit of other men." G. SENA, supra note 205, at 453 (quoting Auletta)(trans.).

208. Article 5, Italian Design Law of 1940 , supra note 96.

209. The official translation, in COPYRIGHT LAws, supra note I, Italy itein 1, article 1(4) says: "if their artistic value is distinct from the imdustrial character of the product with which they are associated." (emphasis added). This conveys the sense of dissociabiltà, G.SENA, supra note 205, at 451 , more than the sense of scindibile, which is the exclusionary criterion actually used in the statute. The translators of Italian Law, supra note 201, at 288, use the term "dissociability" for dissociabillth while rendering scindibile as "separable." This article adopts the same terminology.

210. Article 2(4), Italian Copyright Law of 1941, supra note 200 (as translated, supra note 209); see M. FABIANI, supra note 96 , at 27 . After a long period that witnessed the usual tensions between copyright law (Law of 19 September 1882) and design law (Law of 30 August 1868), the Italian Copyright Law of 1925 had seemed to resolve matters in favor of the umity of art thesis. Nevertheless, the Italian High Court, following the views of Piola-Caselli in TRATTATO DEL DIRITTO D'AUTORE (1927), "forged the doctrine of dissociation that would establish the frontier between the regime of copyright law and that of designs and nodels." F. PERRET, supra note 2, at 257 (trans.). It was this doctrime that the Italian government officially adopted in the Copyright Law of 1941, only one year after the Design Law of 1940. Id. at 257-58; M.A. PEROT-MOREL, supra note 2, at 94-108. For the origins of the controversial theory of dissociation in German idealism, see F. PERRET, supra note 2, at 255-58.

The United Kingdom until 1968 also enforced a regime of noncumulation, which was based, however, on a criterion of imtentions or destination that had at one time also been welcomed by French and Italian case law. M. FABIANI, supra note 96, at 24-25; see supra note 132. 
concurrent. ${ }^{211}$ If a designer seeking access to copyright law should properly have looked to Itahan design law for protection, as is normally the case, then protection in copyright law is precluded whether or not the formal and substantive prerequisites of the design law can effectively be met. ${ }^{212}$ If a design actually registered under the design law might have qualified for copyright protection instead, the act of registration will normally constitute a renunciation of the protection that copyright law might otherwise have provided.213

By expressly adopting the primciple of dissociation, article 2(4) of the Italian Copyright Law recognized that ornamental designs do contain aesthetically valid features. If most ornamental designs of useful articles nonetheless fail to qualify for protection as works of applied art, it is not-in tlieory-because of their utilitarian character or because they lack artistic inerit. Instead, most designs do not retain the artistic values they otlierwise possess when dissociated or separated froin their material supports because industrial design combines the aesthetic and useful qualities of a product into an indivisible wlole. ${ }^{214}$ Sucl designs are fit subjects for the Italian design law: traditionally they obtained a four-year term of protection on deinonstration of novelty and qualitative originality. ${ }^{215}$

The primciple of dissociation is most easily understood in terms of material separability. The figures on the doors of the Florentine Baptistery would retain their artistic features even if embodied in other

211. Italian Design Law of 1940, art. 5, supra note 96; see Franzosi, Droit Italien, reprinted in Grenoble Symposium, supra note 2, at 109-10; F. PERRET, supra note 2, at 258; see also Ilalian Law, supra note 201, at 287.

Article 1 of the Italian Copyright Law of 1941, supra note 200, protects "[i]ntellectual works having a creative character . . . whatever their mode or form of expression." Prior to 1941, Itahan copyright law, like French copyright law, protected works "regardless of their merit or dcstination." The copyright law of 1941, however, suppressed this formula to avoid conferring upon trivial objects the broad protection of copyright law. This reinforced the notion of noncumulation between the two regimes. M. FABLANI, supra note 96, at 29.

212. Françon, Rapport de synthèse, reprinted in GRENOBLE SYMPOSIUM, supra note 2, at 293 (citimg Franzosi and Benussi); Italian Law, supra note 201, at 288. See generally M.A. PEROTMOREL, supra note 2, at 94-99. Protection under the design law may be forfeited either by failure to make timely registration and deposit; or by failure to meet the substantive requirements (novelty and qualitative originality); thus the strict separation between the two regimes can produce harsh results. Sena, Droit italien, reprinted in PARIS SYMPOSIUM, supra note 27, at 172.

213. M.A. Perot-Morel, supra note 2, at 97-99.

214. M. FABLANI, supra note 96, at 26-27; G. SENA, supra note 205, at 443-44, 451; F. PERRET, supra note 2, at 258-59; Franzosi, supra note 211, at 109-10.

215. Article 5, Italian Design Law of 1940 , supra note 96; G. SENA, supra note 205, at 444, 454$55,460-61$. The four-year period of protection originally conferred by Italian design law was atypical. In 1977, the design law was amended to mcrease the term of proteetion to fifteen years, the norm within the European Community. Law of 23 May 1977, No. 265; Z.O. AlaARDI, supra note 61, addenduni (Avvertenza). 
media. ${ }^{216}$ A caryatid supporting an arch is no less sculpture than a similar figure performing no useful function. The design woven into a carpet could also be incorporated into a painting. Textile designs, however, are generally considered an integral part of the fabric itself; for this reason they are said to lack independent artistic value. ${ }^{217}$

This simple test of material or physical separability of artistic features from the useful article does not exhaust the theory of dissociation. Scindibiltà can result from the mere possibility of conceiving a work independently of the object in which it is embodied, that is, when the work possesses "conceptual separability" in the abstract or ideal sense. ${ }^{218}$ The form Cellini gave his saltcellar could also have been apphed to a candy container or to an inkpot, arguably without interfering with the practical uses of these articles. This form would meet the test of conceptual separability. ${ }^{219}$ But the abstract capacity to separate form from object is said to be lacking in the case of most industrial designs and models.220 According to Professor Perret, a leading defender of the theory,

The shape or "form" of a shoe is not superimposed upon the shoe; it constitutes the shoe itself and cannot be transposed to another utilitarian article, such as a lamp. In the one case, the form appears as an mcidental element in the production of the object, in the other as a necessary factor. ${ }^{221}$

Dissociation theory subjects "creations of form," whose aesthetic character is manifested in the lines' and shape of a product, to the de-

216. M. FABLANI, supra note 96, at 27 n.49; G. SENA, supra note 205, at 451 . But Sena holds that not just any stylized rehef superimposed upon metal panels by means of an industrial process could qualify as applied art. Id. at 452 .

217. Although this treatment of fabric designs las been criticized, see, e.g., M. FABIAN1, supra note 96 , at 46 ; G. SENA, supra note 205 , at 451 , a recent case reported by Sena indicates that these designs are protectible only under the design law. A scarf (foulard) by a noted designer was denied copyright protection: "the artistic level, especially in the domain of fashion, is deemed insufficient." Sena, supra note 212, at 172-73 (trans.). Wallpaper and upliolstery designs could claim copyright protection, according to Algardi, if the artistic elements produced a strong effect. Z.O. AlGARDl, supra note 61 , at 256-57 (citing no cases). This suggests that their two-dimensional effect is insufficient of itself to qualify thein as applied art.

218. M. FABIANI, supra note 96 , at 28 . "Separability or dissociability is . . conceptual and slould be understood as a possibility that the object lends itself to being enjoyed as a pure aesthetic fact, independently of its use as an article that can satisfy other needs." G. SENA, supra note 205 , at 452 (trans.).

219. F. PERRET, supra note 2, at 262-63; accord M. FABIANl, supra note 96, at 27 n.49. But see Gaubiac, supra note 48, at 56-57 ("An object constitutes a unity which the law cannot destroy").

220. Italian courts generally "interpret the separation between artistic value and utility in a very restrictive fashion." Sena, supra note 212 , at 172 (trans.). Hence the protective regime will be that governing ornamental designs and models. See, e.g., G. SENA, supra note 205, at 453; Italian Law, supra note 201, at 287-88; see also infra text accoinpanying notes 399-410.

221. F. Perret, supra note 2, at 262-63 (trans.). The same reasoning wonld, according to Perret, apply to automobiles and furniture. Id. at 262. 
sign protection law in force. It excludes from copyright law those functional shapes, devoid of ornainentation, that cannot be conceived of separately from the material objects they "circumscribe in space." 222 In practice, dissociation theory excludes virtually all three-dimensional designs, because only the design that has been added to the object without losing its autonomous character is ever copyrightable. ${ }^{223}$ In theory, a criterion of separability should conduct nost two-dimensional designs safely into copyright law because such designs "can rarely be considered an integral part of the useful article."224 Their incorporation into an object that will be reproduced in series does not alter their expressive capacity. 225 Dissociation theory thus attempts to distinguish the subject matter of copyright law from the subject matter of design law with a high degree of precision; the theory is allegedly more successful than others in drawing the distimction without offending the principle that forbids discrimination on the basis of merit. 226

3. Toward an American Regime of Sui Generis Protection. After Vacheron in 1958, the United States Copyright Office found the Italian theory of dissociation appealing because of its capacity to distinguish copyrightable works of applied art froin noncopyrightable industrial designs with at least formal deference to the Bleistein principle of nondiscrimination. Nevertheless, the Copyright Office considered its

222. F. PERReT, supra note 2, at 263; accord Franzosi, supra note 211, at 110; Benussi, supra note 48 , at 119 .

223. F. Perret, supra note 2, at 263 nn.254 \& 258, 264-67 (citing an exceptional case in United States law that proves the rule, namely, that of certain statuettes of Bali dancers incorporated in a lamp base and accorded copyrightability in Mazer $v$. Stein); see also S. LADAS, supra note 2 , at 842,859 .

224. F. PERRET, supra note 2 , at 263.

225. Id. But Italian Courts have rejected the view that two-dimensional designs remain sacrosanct once embodied in useful articles. See supra note 217 and accompanying text. Benussi, writing in 1977, conceded that certain authors exclude the possibility of concurrent protection in Italian law in all cases, including two-dimensional designs; but he rejected this position. Benussi, supra note 48 , at $121-22$.

The exact status of two-dimensional designs ennbodied in useful articles under current Italian law may be deemed an "open question." M. FABIANI, supra note 96, at 46 (Fabiani used this term in regard to copyright protection of fabric designs in 1975). If this inakes recourse to the design law a necessary precaution, it would be consistent with the letter of the design law itself, which expressly recommends total noncumulation (art. 5(2), Italian Design Law of 1940). Nevertheless, article 2 of the Italian Copyright Law of 1941, which inposed the criterion of separabihty, does not expressly mandate recourse to the design law. Benussi, supra note 48, at 121-22; see infra note 405 and accompanying text.

226. See, e.g., M. FABIANI, supra note 120 , at 29 ("The criterion of separability adopted by our system is . . a subtle criterion, but unexceptionable from the theoretical point of view, even if not always very easy to apply in practice." (citing Ascarelli) (trans.)); F. PERRET, supra note 2, at 26465. But see infra note 409 and accompanying text (views of critics). See also Reichman, After the Copyright Act, supra note 65, at 324-33 (discussing conceptual separability in the Second Circuit). 
criterion of separability a temporary measure to prevent the premature expansion of copyright protection of applied art under a broad reading of Mazer v. Stein .227 Adoption of dissociation theory was merely the first step toward obtaining a major reform of design legislation that the Copyright Office hoped would be even more anticumulatiomst than the Italian model. ${ }^{228}$ The second step would involve both completing the design protection law then under study and strictly defining the new law's relationship to the copyright law so as to exclude designs of useful articles from copyright protection. ${ }^{229}$ The third step was to obtain rapid congressional approval of this scheine before the legislative phase of the general revision of copyright law got under way. ${ }^{230}$

In keeping with this plan, the Copyright Office had officially amended the 1956 regulation in 1959, with a view to placing it on a more defensible legal footing. ${ }^{231}$ In the amended regulation, the test of separability justified immediate denial of registration to "purely functional designs . . . such as those of automobiles and refrigerators . . . which contain no separable pattern or ornamentation."232

The copyright officials knew the risks of this inaneuver. Persons close to the Copyright Office publicly deplored weaknesses inherent in the separability test almost as soon as the 1959 regulation was formally announced. In October 1959, Barbara Ringer wrote:

The borderline between copyrightable and uncopyrightable designs is extremely difficult to draw, although the Copyright Office Regulations as recently amended on June 18, 1959 (37 C.F.R. § 202.10(c)), make the ... attempt. ... The Copyright Office is encountering serious difficulties in attempting to deal with this problem. . . .

227. The Copyright Office assumed that new design legislation would be quickly approved. See supra note 171 and accompanying text. Persons close to the Copyright Office criticized the separability test during 1958-1959, the same period in which the test was officially introduced. See Present Design Protection, supra note 48, at 139-40; infra note 233 and accompanying text (Ringer's criticism). Moreover, the provisions of the design bills endorsed by the Copyright Office in 1959 apparently would have terminated copyright protection of most designs embodied in useful articles, at least as to that industrial embodiment, without regard to separability. This was implemented by H.R. 8873, the Willis Bill, supra note 158 , $\$ \S 28(b), 33$, and S. 2075, supra note $158, \S \S 27(b), 32$, which both proposed amendments to the Copyright Act of 1909. See infra notes 258-63 and accompanymg text.

228. See infra text accompanying notes 264-71.

229. See supra text accompanying notes 167-70; supra notes 195, 227.

230. "We are going to Congress, and we are . . . arguing a broad case that industrial design in this country and in the world indicates the need for sui generis protection . . ." Fisher Address, supra note 107, at 209.

231. See supra text accompanying notes 197-200.

232. Present Design Protection, supra note 48, at 139; see also Hearings 1975, supra note 169, at 1857 (testimony of Barbara Ringer). 
. . . Most important is the fact that at its present state of development the copyright law protects only those designs which can be separately identified as "works of art" and excludes many aesthetically superior designs of useful articles. This distinction seems difficult to justify on the grounds of logic or policy. ${ }^{233}$

Two mandamus actions challenging the legality of the amended regulation's separability test were already pendimg agamst the Register, with more expected;234 the Copyright Office looked to special design legislation to obviate the difficulties inherent in that test. ${ }^{235}$

Recognizing that "the design problem is in ferment internationally" and that there was "general agreement here and abroad that traditional concepts of patent, copyright and unfair competition law do not fit the design situation,"236 the Copyright Office had become actively involved in refining a new bill that was to become "a model for the whole world."237 This bill would afford "sharply limited but realistic protection for original designs . . . tailor-made to ineet the contemporary design situation."238 The project could also block expansion of state unfair competition law in the design field, which was viewed as a significant threat. 239

The bill that emerged in 1959, S. 2075, had benefited from the contribution of experts in all branches of intellectual property law. ${ }^{240}$

233. Ringer, The Case for Design Protection and the O'Mahoney Bill, 7 Bull. CopyruaHT Soc'y 25, 29-30 (1959) (emphasis added). Ms. Ringer published this article while she was Assistant Chief of the Examining Division, United States Copyright Office.

Even earlier, in February 1958, an unsigned article in the same journal, written in support of H.R. 8873 (the Willis Bill, supro note 158) declared:

It is illogical to give very loug and broad protection to some designs, and to withhold protection fron other designs esthetically as valuable-for example, to permit copyright registration for the design of a spoon handle in the shape of the Eiffel Tower, but to deny registration for an unornamented but functionally designed spoon handle.

Present Design Protection, supra note 48, at 139-40.

234. Ringer, supra note 233, at 29-30; see infra notes $419-24$ and accompanying text.

235. Fisher Address, supra note 107, at 211.

236. Ringer, supra note 233, at 30-31. Adding "designs to the subject matter of organic copyright protection," as in previous bills, was "just as inappropriate as lumping designs under the patent laws had been a century before." Id. at 27.

237. Fisher Address, supra note 107, at 211 .

238. Ringer, supra note 233, at 31; ReGISTER's DRAFT REPORT 1975, supra note 36, ch. V11, at 7. George Cary and Barbara Ringer were the Copyright Office's emissaries to the drafting committee. Design Protection Hearings 1960, supra note 115, at 48 (testimony of Judge Giles S. Rich).

239. Ringer, supra note 233, at 29-30; see infra notes $419-24$ and accompanying text.

240. S. 2075, supra note 158, introduced May 28, 1959. The basis for discussion had been the Willis Bill, H.R. 8873, supra note 158, introduced July 23, 1957. The new bill, known as the O'Mahoney-Wiley-Hart Bill, was presented to the 86th Congress. See Latman, supra note 169, at 280. For the committee of experts, see supra notes 169-70. Questions addressed by similar groups of foreign experts were in this way approached without the nationalistic infighting that seems to have choked off some of the nuore promising innovations that had been developed overseas. See supra notes 114-15. But see infra note 347 (divisions among leading United States scholars). 
A basic premise of the bill's supporters was that full copyright protection of industrial designs was "too broad and vague." 241 They also dismissed the misappropriation theory of unfair competition law as grounded on "virtually nonexistent standards."242 Nevertheless, unlike foreign reform proposals, the new design bill was to "rest generally on the concept of originality, which in a broad sense can be called the primciple of copyright." 243 There would be no requirement "that the design be either 'inventive' or novel-the fundamental stumbling blocks of design patent law."244 The bill's supporters rejected the patent approach as too narrow, inflexible, slow and costly for the fastmoving, short-lived products of competitive industries; too absolute in its scope of protection; and too susceptible to the "judicial hostility"

241. Ringer, supra note 233, at 30; see supra notes 108-09 (views of Fisher). Bogsch, appraising the reform from the perspective of foreign law, warned that the copyright requirement of "a work of art" could cxclude many categories of attractive and distinctive designs not rising to the required level; hence copyright protection risked being too narrow. Bogsch, supra note 106, at 5.

Among the "numerous practical and theoretical disadvantages" of copyright protection, Register Fisher drew attention to the duration of such protection; to the fact that copyright law would protect even designs not apphed to an article of utility; and to the need for a system of registration as recognized "both domestically and internationally." Design Protection Hearings 1960, supra note 115 , at 56, 57,61, 63 (testimony and statement of Arthur Fisher). But see Duchemin, supra note 71 , at $184-85$ (concerning registration).

242. Ringer, supra note 233, at 30. "By extending common law concepts of unfair competition to the design field, and with the tendency to eliminate the eleinents of 'passing off' or misrepresentation, not merely a loug term but a perpetual set of rights may be created. A number of recent cases illustratc this tendency." Design Protection Hearings 1960, supra note 115, at 57 (statement of Arthur Fisher); see infra notes 419-24 and accoinpanying text.

243. Ringer, supra note 233, at 31; see also Design Protection Hearings 1960, supra note 115, at 61 (testimony of Arthur Fisher); Fisher Address, supra note 107, at 209-10 ("the pending bills are all based essentially on primciples of originality and copyright"); supra note 147.

244. Ringer, supra note 233, at 31; see also Latınan, supra note 169, at 281 ("Original in the sense of imdependent creation, created without copying"). This was to be implemented in S. 2075, supra note 158, by scctions 1 (a) and 2 when read together. In contrast, foreign design laws require at least a novelty test, and most of them also require a qualitative originahity tcst akin to nonobviousness in the United States Design Patent Law, 35 U.S.C. $\$ \S 101-103,171$ (1982). See supra notes $109,121,125$. The foreign law requirement will usually be termed "qualitative origmality" in this paper in order to distinguish it from originality in the copyright sense.

Whether S. 2075 as drafted truly implemented a test of mere "independent creation," as its sponsors contended, is open to question. The ambiguity arose in part from section 2(a), which excluded "a design that is staple or commonly known." S. 2075 \$\$ 2(a), 3, supra note 158. Patent lawyers at the time spotted the ambiguity of section 2. See Resolution of the Milwaukee Patent Law Association, Design Protection Hearings 1960, supra note 115, at 93-94; Design Protection Hearings 1960, supra note 115, at 181 (letter from Robert C. Watson, Commissioner of Patents). Patent law specialists have again pointed to the same ambiguity in a recent successor bill (H.R. 20, 97th Cong., 1st Sess. 1983). See Fryer, Protection of Ornamental Designs of Useful Articles-The Legislative Opportunity, reprinted in ABA-Section of PATENT, TRADEMÁrk AND COPYRIGHT LAW, SUMmarY OF PROCEEDINGs 166-67 (1982)(uncommon design and uncommon variation requircinents); infra text accompanying notes 581-98. 
that was characterized as "usual."245 Yet repeal of the design patent statute was neither proposed nor desired. 246

To qualify for protection under the proposed design law, a mimimum degree of creative content was required: standard, commonplace, or staple designs were expressly excluded. ${ }^{247}$ Instead of the search of prior art required by the design patent law, the bill provided for "an 'administrative' screening process, similar to the trademark opposition procedure."248 The design to be protected would "relate . . . to (1) the appearance (2) of a useful article. Thus the utility of the article, while a touchstone to coverage, is not what is being protected." 249 The bill ex-

245. Ringer, supra note 233, at 25-26. In introducing H.R. 8873 (known as the Willis Bill), supra note 158, Representative Willis suggested that patent law was not the place to deal with design protection. 103 CoNG. REC. 12,504-05 (1957). "The novelty search was costly, time-consuming, and not always . . . realistic" and the standard of "invention or nonobviousness" was "impossible . . . to ineet." Bogsch, supra note 106, at 4-7. Expense and delay were prohibitive: in 1959, a lapse of one year between filing and issuance was typical; only about $12 \%$ of design patents were issued in six months or less, $52 \%$ took one year or more, $12 \%$ took more than two years, and there was a backlog of 8700 design patent applications pending or awaiting action. Ringer, supra note 233, at 25-26. "Patents for designs have been difficult to obtain and nore difficult to sustain and many have felt it was not worth the effort and the protection illusory." Design Protection Hearings 1960, supra note 115, at 51 (testimony of Judge Giles S. Rich).

Professor Brown discovered that the United States Court of Appeals for the Second Circuit, the country's foremost intellectual property court, had upheld only two design patents between the 1920's and the 1970's. B. KAPLAN \& R. Brown, CASES ON CopYright 158, n.N (3d ed. 1978). Statistics recently published by the Patent and Trademark Office show an invalidation rate at the appellate level of 100 percent for the period 1968-1972, and 67 percent for the period 19731977. Patent and Trademark Office Study of Court Determinations of Patent VALIDITY/INVALIDITY, 1973-1977, reprinted in Pat. TRADEMARK \& CopYright J. (BNA) no. 455, D-1 (Nov. 22, 1979) [hereinafter cited as PTO INvalidation Study]. On the period 1973-1977, see Reichman, After the Copyright Act, supra note 65, at 308-12, 333-61 (rcports new trend for 1974-1983).

246. "II]t is agreed that there is an area appropriate for design patents where invention can bc establisled, where novelty can be established and where the greater protection that follows from being able to assume this burden is appropriate. The proposed legislation does nothing to disturb design patents." Fisher Address, supra note 107, at 208. This position was consistently inaintained. See, e.g., Latman, supra note 169, at 284; REGISTER's DRAFT REPORT 1975, supra note 36 , ch. VII, at 12.

247. Despite the requirement of originality in the sense of independent creation (not copied), see supra note 243 , the protected design, although not subject to "any test of novelty, unobviousness, or inventiveness, . . . cannot be so staple or commonly known as to lack a minimum of creativity." Design Protection Hearings 1960, supra note 115, at 70 (statement of Alan Latman). Section 3 of S. 2075, supra note 158, required substantial adaptations of inatter otherwise in the public domain. For the difficulties of reconciling these provisions, see infra text accoinpanying notes 581-98.

248. Latman, supra note 169 , at 281,283 ; see $\S 12$ of S. 2075 , supra note 158 . This was more in line with the trend in foreign design law. See, e.g., Englert, supra note 96, at 784.

249. Latman, supra note 169 , at 280 . Under S. 2075, the protected design "consists of those original elements of a useful article that are intended to give the article an ornamental appearance." S. 2075 § 1(b)(1), supra note 158; see also Bogscl, supra note 106, at 6 (protcctible design must at least be "attractive and distinctive"). 
cluded designs dictated solely by the function or purpose of the article embodying the design. ${ }^{250}$ The term of protection was to be five years, reduced from an earlier proposal of ten years that was felt to go "far beyond the needs of most segments of imdustry."2s1 The proposed law also required registration within six months from the time the design was "made known," to avoid technical forfeiture.252

The Umited States "design copyright law" proposed im 1959 was to operate side-by-side with the preexisting design patent law. The design patent law would contmue to afford short-term protection to ornamental designs of useful articles agamst identical or substantially similar designs even when independently created, provided that the prerequisites of ornamentality, novelty, and nonobviousness had been met. ${ }^{253}$ The design copyright law would offer short-term protection to ornamental designs of useful articles that were "created without copying" agamst unauthorized copying but not against independent creation. ${ }^{254}$ The dual regime of design protection that resulted was a major innova-

250. S. $2075 \S 2$ (c), supra note 158 . This excluded utility models. See infra text accompanying notes $377-86$.

251. S. $2075 \S 5$, supra note 158; see Latman, supra note 169 , at 282 . Duration was not a major issue.

252. S. $2075 \S \S 4,9$ (a), supra note 158. A design was to be "made known" when, "by the proprietor of the design or with his consent, an article embodying the design is anywhere publicly exhibited, pubhicly distributed or offered for sale, or sold." S. 2075 \$(b), supra note 158. Registration required an oath under section 9 (d) that the design had in fact been "inade known."

The fact that technical forfeiture would occur for failure to register within six months after the design was inade known was not necessarily inconsistent with the notion of a "design copyright" in view of the technical forfeitures for publication without notice then normal under the 1909 Copyright Law.

253. "Because of the broader scope of patent protection, however, it was provided that design protection under the bill would terminate as soon as a design patent issued." Latman, supra note 169, at 284; see also REGISTER's REPORT 1961, supra note 45, at 14-15. The duration of protection in design patent law is $3-1 / 2,7$ or 14 years.

254. S. 2075 § 8(d), supra note 158. Register Fisher testified that the new bill's "prohibition against actual copying is all that is desirable in the public interest or for the protection of the creative designer." Design Protection Hearings 1960, supra note 115, at 56 (testimony of Arthur Fisher).

Foreign design law, even if it delnands high subject matter prerequisites, rarely protects against more than "actual copying." M.A. PEROT-MOREL, supra note 2, at 19. This anomaly is criticized particularly in the Federal Republic of Germany where subject natter prerequisites include a form of nonobviousness but protection extends to copying only. See, e.g., Englert, supra note 96, at 778-79. Continuation of the Design Patent Law along with S. 2075 lielped to ward off a similar anomaly in the American reform. Without the design patent law, the apparently low subject matter prerequisites of sections 1 and 2 of S. 2075, see supra note 158, could tend to drift upwards toward the novelty and nonobviousness platforms vacated by a repealed design patent law. 
tion despite its imperfections. ${ }^{255}$ By allowing users to choose the kind of design protection they needed without seeking to reconcile the patent and copyright approaches in a single legal regime, the proposed law departed froin the AIPPI's Tokyo Resolution of 1966, which had invariably given rise to design laws based on the industrial property paradigm. ${ }^{256}$

The line of demarcation to be established between the new design law and the Copyright Act of 1909 was crucial to the success of this proposal. Would a manufacturer, offered a choice between soft design protection on soft terms for five years or hard design protection on hard terms for a maximum of fourteen years, also be entitled to claim soft protection on soft terms for up to fifty-six years in copyright law? Could a designer circumvent botll components of a dual regime of design protection by asserting that a particular design possessed "separable" artistic values or that it otherwise constituted a "work of applied art?"

The group of American experts answered both questions in the negative. ${ }^{257}$ They said that the line of demarcation between copyright law and design protection law should be based on the "usefulness" of

255. Bogsch, supra note 106, at 9. The term "dual system" was used by Arthur Fisher in his last public address, which urged the American Bar Association to support sui generis design legislation. Fisher Address, supra note 107, at 210.

As to imperfections: "The draftsmen of S. 2075 have not solved all of the problems since they were faced with the necd for a delicate balance of interests which defies the drafting of a perfect piece of legislation in this area." Latman, supra note 169, at 286. Perhaps the biggest defect of the dual regime was a lack of clarity concerning the requirement that protectible designs not be "staple or commonplace." See S. 2075, supra note 158, \& 2 (uncommon design), \& 3 (substantial revision of common design); see also infra text accompanying notes 581-600.

256. For the statement of basic points to guide future design legislation endorsed by the Association for the Protection of Industrial Property (AIPPI) in I966, see S. LADAS, supra note 2, at 868-71. For a major reform adopted in this period, see, for example, Reichman, After the Copyright Act, supra note 65, at 293-97 (the Benelux reform). The 1959 American proposal seemed to anticipate some of the criticism that would be leveled at the generation of design laws infiuenced by the AIPPI model. See Reichman, After the Copyright Act, supra note 65, at 366-73.

257. See Fisher Address, supra note 107, at 210. Techmically speaking, the negative answers had been given by section 28 of the Willis Bill of 1957 and in the proposed amendment to section 33 of the Copyright Act the bill contained. See H.R. 8873 (Willis Bill), supra note 158. The effect of the Willis Bill would have been to amend the Copyright $A C t$ so that "an ornamental design of a nsefuI article shall not be subject to copyright under the Copyright Law." Bogsch, supra note 106, at I0. The same approach was then carried over into sections 27 and 32 of S. 2075. This was consistent with efforts of the Copyright Office, after Mazer v. Stein, to "resist . . t the trend toward long-term copyright claims in the design of useful articles." Design Protection Hearings 1960 , supra note 115, at 57 (statement of Arthur Fisher). But vested interests launched so powerful an attack on these provisions that the sponsors subsequently backed down. See infra text accompanying notes 272-98. 
the article in which the design or work of art was embodied. ${ }^{258} \mathrm{~A}$ broad definition of a "useful article" was accordingly drafted to include "an article normally having an intrinsic function other than merely to portray its own appearance or to convey information."259 Under this definition, works of fine art were not useful articles "because their normal and imtrinsic function is to portray their own appearance"; similarly, books, maps or documentary films did not fall within this definition because they "convey information." 260

258. S. $2075 \S \S 1$ (b)(1), (2), 32, supra note 158 . "[T] $]$ here no longer would remaim the impossible task of determining what is a 'work of art.' Substituted is the inquiry as to utility which, while by no means a simple one, seems much more appropriate and workable." Latman, supra note 169, at 280.

If S. 2075 was intended to repulse "vested interests," see supra note 257, the method was subtle. In theory, the designer or manufacturer who took the position that his three-dimensional model was not applied to a useful article could place a copyright notice on it and atteinpt to ignore the design law. In practice, the very existence of a sui generis law protectimg designs of useful articles made this option risky because failure to obtain timely registration of the design of a useful artiele under the design law forfeited all protection. Hence, a designer or inanufacturer im doubt, while contending that his models were not "designs of useful articles," was nonetheless induced to register in design law lest all protection be lost if a court found the model in fact to be a "design of a useful article." To register under the proposed design law, the apphicant had to declare that the article was a useful article by mdicating its utility under section 9(c)(3) of S. 2075. This specification would almost certainly have entailed mandatory exclusion from copyright law under section 32 of S. 2075 (which proposed an amendment to the Copyright Act of 1909). (Compare the similar effect of registration under the Italian Design Law of 1940, discussed supra in text accompanying note 213.) If it were subsequently determined that the article was not a useful article despite the above-mentioned declaration, the design protection rights were nonetheless expressly preserved by section $9(\mathrm{e})$ of the bill.

As to nonembodied two-duneusional designs, as well as two-dimensional drawings or photographs of three-dimensional objects, the proposed design law would arguably have eliminated both the preexisting exception permitting copyright in models derived from cartoons and protection in copyright law for the two-dimensional design if "utilized in the design of a useful article." S. $2075 \S \S 27,32$, supra note 158; see infra notes 311-23 and accompanying text. Once again, the safe approach was to register any two-dimensional design or drawing of an article that could be useful as "the design of a useful article" when the article was about to be marketed. In this event, copyright protection as to the useful article, but not as to its two-dimensional representation, was lost by operation of section 32 of the design law, which would have modified the Copyright Law of 1909.

259. S. $2075 \S \S 1$ (b)(2), 32, supra note 158 (which would have introduced the same language into the Copyright Act of 1909). This definition was carried over from the Willis Bill. Cf. Copyright Act of $1976 \$ 101,17$ U.S.C. $\$ 101$ (1982)(final definition of a useful article).

260. Bogsch, supra note 106, at 7 (referring to the Willis Bill); Latman, supra note 169, at 280. A goblet on display would remain a useful article because it normally had an intrinsic (utilitarian) function related to drinking. Id. But what if a painting were later embodied im a tray; would it become the design of a useful article and, as a tray, be governed by the design bill while retaining copyright protection as a paimting? Such a solution would have implemented the approach of the Roscioni Report of 1962, see supra note 115; Pérot-Morel, Pavia Conference, supra note 87, at 389. The Roscioni proposal would have protected the painting as a work of art im copyright law, while forcing products to whicl the painting was applied, such as an uplolstery design, into a special design law. Id. Sections 27 and 32 of S. 2075 can be read this way, and Bogsch thought that the Willis Bill liad clearly taken this option. Bogsch, supra note 106, at 10. 
Design protection attached only after einbodiment in the useful article, and normally after disclosure through marketing. ${ }^{261}$ Until design protection attached, the design, if a work of art not embodied in a useful article, would retain any copyright protcction it had.262 After disclosure through marketing, the design of the useful article would be protected only by design law; even if a work of art, it would become inehigible for copyright protection against other useful articles. A previously copyrighted work of art later "utilized in the design of a useful article" would similarly cease to enjoy copyright protection as to the useful article, which would instead be governed by the design law. ${ }^{263}$

"Industrial designs" were in this way to be quarantined and limited to a term of protection that could vary from a minimum of three and one-half to a maximuin of fourteen years and that would in practice seldom exceed five years, a lead-time period. ${ }^{264}$ The line of demarcation with copyright law, the weakest link in any special regime of design protection, ${ }^{265}$ was to be defended by a policy of anticumulation that rigorously excluded commercially exploited designs of useful articles. ${ }^{266}$ Every temptation of the unity of art thesis to which individual

Register Fisher may not have gone this far, however, or having gone this far, may have deemed it prudent to pull back. See Fisher Address, supra note 107, at 208 ("I think here is where we should wrestle with improvement of the legislation"). Professor Latman argued that the painting applied to a tray was not the "design of a useful article," because "use as a tray would not be the intrinsic function of the painting." Latman, supra note I69, at 280 (emphasis added).

261. The Register of Copyrights opposed registration of drawing board designs without actual manufacture of the object portrayed, to avoid harassinent of manufacturers. Design Protection Hearings 1960, supra note 115, at 63 (testimony of Arthur Fisher); see Latman, supra note 169, at 282.

262. S. $2075 \$ 29$, supra note 158 . If the design had no copyright protection in this period, it would look to the common law. Latman, supra note 169, at 282, 285.

263. S. $2075 \S \S 27,29,32$, supra note 158; Latinan, supra note 169, at 282, 285. This was called a "terminable copyright." Waldheim, Don't Maim, supra note 201, at 160-61. Bogsch applauded this concept. Bogsch, supra note 106, at 10; see also Present Design Protection, supra note 48, at 141. After the expiration of design protection, the proprietor would lose his exclusive rights to the design of the useful article under both copyright and design laws. "His trademark and unfair coinpetition rights may, however, be significant," and in any event the proprietor continued to enjoy the full term of copyright protection "against unauthorized appropriation of the work in any non-useful application (e.g., use as a drawing or im a motion picture)." Latınan, supra note 169, at 285.

264. See supra note 253. "I suggest that the very shortness of the term may become an important protection to industry from excessive damage claims in future design suits." Fisher Address, supra note 107, at 209; cf. infra notes $374-76$ and accompanying text (effects of four-year term in Italian design law prior to 1977).

265. See Present Design Protection, supra note 48, at 140; Bogsch, supra note 106, at 10 (the Willis Bill "permitt[ed] no restrictive 'categories' with the difficulties of definition and jurisdictional demarcation"); cf. Pérot-Morel, Pavia Conference, supra note 87, at 390, 393 (fundamental problem of specific design legislation in all national judicial systems is its relation to copyright).

266. "[T]he stretching of the copyright law to cover ornamental designs of useful articles is rapidly developing an attitude of vested imterest in long-term rights of an undesirable nature in a 
judges might succumb in dealing with particularly appealing designs or particularly grievous acts of misappropriation was thus precluded as a matter of law.

To its supporters, this scheme could reconcile the different needs of different categories of users by allowing them to choose the kind of design protection that best suited their interests without necessarily submitting to the rigors of industrial property law and without any possibility of obtaining the long duration of copyright law. ${ }^{267}$ In effect, S. 2075 had unified the treatment of industrial art within a coherent legal framework by eliminating many of the inconsistencies that otherwise accrued from the distinction between copyrightable "applied art" and noncopyrightable "industrial designs." The subject natter that the Berne Convention had artificially divided between copyright law and design law at Brussels in $1948^{268}$ would be reunited within a twopronged American regime that operated outside the copyright system. An ad interim "separability" test would no longer discriminate in favor of two-dimensional designs or three-dimensional kitsch;269 borderline items that had crept into copyright law after Mazer $v$. Stein, such as jewelry, dolls and toys, might be rejected;270 and discredited or "demonstrably unreliable" legal criteria that emphasized the intentions of the author or the number of copies to be produced or, above all, the aesthetic value of the work in question were to be avoided.271

diversity of articles and industries." Design Protection Hearings 1960, supra note 115, at 57 (statement and testimony of Arthur Fisher); see supra note 257.

267. S. 2075 \& 28 , supra note 158 . "S. 2075 . . . should give creative designers and the industries they serve, particularly the smaller and medium-sized firms . . . the short-term protection they are entitled to .... [I]t should [also] reheve the copyright law and the Copyright Office from an imcreasingly difficult and undesirable burden . . . Design Protection Hearings 1960, supra note 115, at 57 (statement of Arthur Fisher).

268. See supra text accompanying notes 97-104.

269. See supra note 233 and accompanying text.

270. Design Protection Hearings 1960, supra note 115, at 20 (letter from L. Quincy Mumford, Librarian of Congress). The aim of expelling costume jewelry can be inferred from the general policy of repulsing "vested interests." See, e.g., supra note 266. But Bogsch, then at the Copyright Office, thought otherwise: "Most items of jewelry, for example, such as a necklace or an ornamental pin, portray only their own appearance and having no utilitarian or functional purpose would reinain protectible by the present copyright law. But a cufflink performing a useful function . . . would probably fall under the new design law." Bogsch, supra note 106, at 10 . The willingness of courts to find jewelry a "usefnl article" as defined in S. 2075 thus could not be taken for granted even then. See Reichman, After the Copyright Act, supra note 65, at 326-27, 375-77.

271. Latman, supra note 169 , at 280 . Despite introduction of the separability test, which officially entered United States law for the first time with Regulation Section 202.10(c), June 18, 1959, see supra note 199, the Register conceded, under questioning, that ornamental designs were in fact subject to a test of aesthetic value before being accepted for registration. See Design Protection Hearings 1960, supra note 115, at 83 (testimony of Arthur Fisher). 
Critics of the scheme set forth in S. 2075 found it open to attack on a number of grounds. Any line of demarcation based on the nature of the material support derogated from the fundamental concept of the "work" and seemed to reinstate the old dichotomy of art and utility. ${ }^{272}$ Dissatisfaction with attempts to separate designs and models from artistic property had led to the umity of art position in France and later to the compromise at Brussels. Viewed froin this perspective, the American proposal embodied in S. 2075 could be, and was, compared to regimes antedating the effective recognition of applied art by the Berne Umion in 1948. For this and other reasons, the bill was criticized as out of line witl the prevailing international position. ${ }^{273}$

Another ground of attack was that S. 2075 "maimed" the concept of copyriglit by terminatimg the protection of subsequent works to which the origmally protectible work liad been applied.274 For example, a cartoon character protected in copyright law as a work of art would cease to be protectible agamst enbodiments of that character in useful articles once the copyright owner had himself authorized such an embodiment in a T-shirt or a toy doll, and the period of special design protection had expired. Critics said such termination maimed the copyright in the cartoon in derogation of general principles of copyright law.275

272. According to this view, use of the material support as the real basis for exclusion from copyright law makes decisions concerning protectibility turn ou a factor completely exterior to the creation itself. See, e.g., F. PERRET, supra note 2, at 242; supra notes 42, 56 and accompanymg text. Nevertheless, proponents of the Uniform Senelux Designs Law, supra note 117, negotiated in the 1960's, placed emphasis on the material support. See Reichman, After the Copyright Act, supra note 65 , at $293-97$.

273. "Perhaps the drafters of S. 2075 inserted these provisions because it is difficult to define an exact dividing line between useful articles which embody works of art and those which embody merely design. So the proponents of this bill resolved the difficulty by erasing the line and by assuming that art ceases to be art when it becomes part of a useful article." Waldheim, Don't Maim, supra note 201, at 161, reprinted in Design Protection Hearings 1960, supra note 115, at 25. Waldheim was counsel to Walt Disney Productions, Inc. Senator Talmadge, sponsor of the opposing bill, S. 2852, which Disney Productions favored, introduced Waldheim's article into the record. Design Protection Hearings 1960, supra note 115, at 24 (statement of Senator Talinadge).

The world trend, according to this group, favored the unity of art position. See Design Protection Hearings 1960, supra note 115, at 31, 35 (testimony of Arnall, who relied on material concerning United Kingdom and New Zealand law); supra note 132 (atypical situation in United Kingdom). A later claim by Finniss, Director of the French National Institute of Industrial Property, supra note 52, at 628-29, about a world trend towards the unity of art position was introduced at the 1965 Hearings by the same group. See Design Protection Hearings 1965, supra note 114, at 48-49 (testimony and statement of Ellis Arnall). For the role of Finniss abroad, see supra notes 114-15.

274. Waldheim, Don't Maim, supra note 201, at 160.

275. Waldheim, Don't Maim, supra note 201, reprinted in Design Protection Hearings 1960, supra note 115 , at 25 . The concept of a terminable copyright, however, was a key feature of the Roscioni Report to the European Community in 1962. See supra notes 115, 260. 
This argument ignored the fact that industrial designs are legal lybrids that partake botll of artistic and industrial property law. Policies favoring the protection of the design of a useful article qua artistic work may thus interfere witl policies favoring free competition in the "material supports" in which the self-proclaimed artistic work lias been embodied. Indeed, it is precisely the capacity of works of applied art to compete in both the narket for artistic works and in the general products market that aggravates the design problem; no facile invocation of general principles of copyriglt law will make this two-inarket conundrum disappear. ${ }^{276}$ To say that a copyriglited work of art is norinally protected when transformed into a different artistic medium is not a sufficient answer to questions concerning the desirability of encumbering trade on the general products market simply because a given product also makes use of a copyrighted work.277 It does not seem unreasonable to limit, on economic grounds, the applicability of artistic copyrights to useful articles, when useful articles are normally governed by imdustrial property regimes that impose stringent preconditions to restraints on free competition. ${ }^{278}$

For this reason, article 2(5) of the Berne Convention, as revised at Brussels in 1948, permitted meinber states to determine the apphicability of domestic copyright laws to works of applied art as well as the conditions under whicli such works should be protected. ${ }^{279}$ If terminating the copyright in a doll made from a cartoon claracter is not a techmique widely used abroad, this is not necessarily because other countries are as respectful of the "totality of copyright" as is France under the unity of art theory. ${ }^{280}$ The trend in foreign law after 1958,

276. See, e.g., F. PERRET, supra note 2, at 13 ("Industrial aesthetics, born under the sign of the most ferocious competition, is devoted to purely commercial objectives.") (trans.); Gaubiac, supra note 48 , at 3 .

277. Design Protection Hearings 1960, supra note 115, at 56 (testimony of Arthur Fisher); accord F. PERRET, supra note 2, at 13 (given comparable technical quality and resale prices, the appearance of the product may become determinant, especially when supply exceeds demand); infra text accompanying note 286 (quoting Register Fisher); see also 1 M. NimMER, supra note 1, \$ 2.08[B], at 2-96.1 (two-market discussion).

278. See. e.g., Bogsch, supra note 106, at 5; Denicola, supra note 20, at 723-27; Note, supra note 10 , at $1527,1532-34$. Within copyright law itself, there is a relationship between the nature of the subject matter and the strength of the copyright protection to be granted. A. LATMAN, supra note 160, at 29; see, e.g., Kepner-Tregoe, Inc. v. Carabio, 203 U.S.P.Q. (BNA) 124, 132 (1979)(copyright in a management training program is said to be "thin").

279. See supra notes 98-104 and accoinpanying text. Supporters of S. 2075 could also claim that it conferred copyright protection, not patent-type protection, and that both the Berne and Geneva Conventions permitted member countries to limit the duration of protection accorded applied art. See supra notes 27, 101 and accompanying text.

280. A statement by Finniss endorsing "the principle of 'totality of copyright," see Finniss, supra note 52, at 629, was introduced at the 1965 Hearings by the group that had opposed S. 2075. See Design Protection Hearings 1965, supra note 114, at 48-49 (testimony and statement of Ellis 
contrary to assertions made at that time, was away from the unity of art position and toward regimes of partial cumulation. ${ }^{281}$ These regimes tend to admit a limited number of exceptional designs to copyright law while relegating the rest to special design laws of varying degrees of efficacy. ${ }^{282}$ Accordingly, these regimes have hittle need for a "terminable copyright."'283

The decision of the drafters of S. 2075 to use the useful article to denarcate between copyright and design protection law was not rooted in the notion that ornainental designs of useful articles were "less valuable aesthetically or culturally than 'works of fine art," whatever the United States position had been in the past.284 Instead, they chose this line of deinarcation primarily because "the impact of long term statutory protection upon the consuming public and the national economy is much greater in the field of useful commodities than . . . nin the area of fine arts" and because "articles . . . bought for use have much greater economic significance than those . . . bought solely for display." 285 As

Arnall, Counsel to Walt Disney Productions); see also id. at 23 (statement of Senator Talmadge)(commendable goal to preserve "the totality of copyright protection").

281. After the Lisbon Revision of the Paris Convention in 1958 the "movement for absorption of industrial designs and models into the law of artistic property seems to lave spent itself." $S$. LADAS, supra note 2, at 837 (who otherwise appears sympathetic to the unity of art position). The judge-made regime of partial cumulation in the Federal Republic of Germany remains the oldest and inost claracteristic exemplar of this system within the European Community. Pérot-Morel, Pavia Conference, supra note 87, at 383. The latest converts in Western Europe to legislated attempts at partial cumulation imclude the Nordic Countries, that is, Finland, Denmark, Norway, and Sweden, and the Benelux Countries, that is, Belgium, the Netherlands, and Luxeunbourg. See supra note 117; Pérot-Morel, Pavia Conference, supra note 87, at 385-86. For the reconnmendation of the Commission of European Communities in 1977 that regimes of partial cumulation should be adopted, see Gaubiac, supra note 48, at 68-69. For the view that the Court of Appeals for the Second Circuit has installed a regime of partial cumulation in the Umited States, see generally Reichman, After the Copyright Act, supra note 65.

282. Under such circumstances, the demand for full copyright protection for designs of useful artieles can turn out to mean very little protection in practice because few designs meet the courts' elevated subject matter requirements. See, e.g., V. von Pilgrim, supra note 7, at 118. But see S. LADAS, supra note 2, at 840-41. Ladas made too much of a 1954 decision in the Federal Republic of Germany thought to open a liberal phase in copyright law. This decision was atypical in what otherwise continued to be the inost restrictive regime in the European Community other than Italy. See, e.g., E. UlMER, supra note 7, at 148; Reuner, supra note 91, at 44-45.

283. Arguably, the need for a "terminable copyright" decreased despite endorsement by the Roscioni Report itself, see supra notes 115, 260 and accompanying text, because the leading European Community countries already were, or would soon becone, so lieavily committed to the industrial property paradigm in the field of design protection. Pérot-Morel, supra note 126, at 146. It therefore became increasingly difficult to obtain a copyright in the design of any useful article in the first instance. See generally Reichman, After the Copyright Act, supra note 65, at 283-97 ("The Benelux Experience"), 333-40 ("Partial Cunulation in the German Manner").

284. Present Design Protection, supra uote 48, at 140. Register Fisher stressed the artistic validity of contemporary design, including the work of American designers. Design Protection Hearings 1960, supra note 115, at 58, 81-82 (testimony of Arthur Fisher).

285. Present Design Protection, supra note 48, at 140. 
Register Fisher put it in 1960: "The appearance of the container may turn out to be the single most important fact in the marketing, sale, and distribution of the commodity, with corresponding need of protection to the company that develops the new appearance so the design will not quickly be stolen and copied." 286

The breadth of protection accorded applied art in countries following the unity of art thesis inagmified these economic concerns. Register Fisher warned agamst

misapplying the copyright law that was developed for totally different purposes, with its long term and a whole series of different formahities, to the broad scope of American industry in which design today is a simple fact and where no more than a short 5- to 15-year term is appropriate. ${ }^{287}$

The drafters of S. 2075 did not drive works of applied art into a design law based on the patent-law paradigm, as had many European regimes. ${ }^{288}$ The American proposal attempted to relegate applied art to a mini-regime of copyright law, which would coexist with a stricter regime of design patent law, in return for a shortened period of protection. At a time when copyright protection abroad was being cut back, because of what were widely perceived to be the excesses of the copyright approach, the United States scheme, as originally proposed, sought to expand the protection available for ornamental designs to a very broad base of users. ${ }^{289}$ This scheine sought to provide short-term protection, against copying only, to virtually all producers of both twoand three-dimensional designs, including artisans and small industrial users, instead of long-term copyright protection to a few privi-

286. Fisher Address, supra note 107, at 207.

287. Fisher Address, supra note 107, at 209. In 1961, the new Register of Copyrights, Abraham Kaminstein, declarcd:

We do not believe . . that it would be appropriate to extend the copyright law to industrial designs as such. In this area there is a delicate balance between the need for protection on the part of those who originate and invest in a design, and the possible effect of protection, if overextended, in restraining coinpetition.

REGISTER'S REPORT 1961, supra note 45, at 13.

288. See Reichman, After the Copyright Act, supra note 65, at 366-73.

289. The Aınerican proposal in S. 2075, while allowing patent protection for a few exceptional designs, gave most designs a form of copyright protection they could not generally acquire abroad, albeit at the price of a short term of duration. See Bogsch, supra note 106, at 9; cf. V. von Pilgrim, supra note 7, at 118 ("my proposal to reinove applicd art froin copyright law and to protect it under a separate law is intended to improve the legal status of these works in theory and in practice. . . . [A]n adequate legal protection of applied design . . . currently does not exist, despite the existence of two laws, owing to the demarcation lines drawn by the case law.") (trans. Reinhardt Sonnenberger). Only the unity of art position gave unore protection. See supra notes 70-78 and accompanying text. 
leged users or certain sectors of industry and short-term, patent-type protection to manufacturers of exceptional designs. ${ }^{290}$

The solution proposed by the committee of experts im 1959 suffered from being ahead of its time ${ }^{291}$ rather than from the regressive tendencies attributed to it by a powerful lobby. ${ }^{292}$ Far from "maiming" copyright law, the reforms embodied in S. 2075 would have checked the drift toward giving "too few designs . . . too much protection" that followed Mazer v. Stein . ${ }^{293}$ The late Arthur Fisher, who as Register of Copyrights had championed S. 2075, explained its importance im a prophetic statement shortly before his death:

It isn't a matter of doing nothing and then finding that the problem has taken care of itself. If nothing is done, the problem will increase in complexity and without the protective features that have been carefully worked out here. And I believe that this is not only the experience here in the United States but in the world at large. 1 think . . . the matter has becolne so urgent that we should deal with it promptly before we find vested interests in different industries, as we have found in other situations, and where it will be much more difficult in a few years to deal with the matter effectively. ${ }^{294}$

290. See, e.g., Duchemin, supra note 71, at 184-85; Duchemin, supra note 2, at 73-77 (criticizing the bias against artisans and the sinall- and medium-sized producers under most current regimes); supra note 288.

291. See infra text accompanying notes 610-12, 624; see also Z. O. ALGARDI, supra note 61, at 351-52; Duchemin, supra note 2, at 82; supra note 289 (view of von Pilgrim). For the view that the Willis Bill (forerunner of S. 2075) was in the inainstreain of national and international reforms, see Bogsch, supra note 106, at 11-15 (he is now Director General of the World Intellectual Property Organization (WIPO)).

292. The Justice Department and certain industries registered formal objections to the reform of design protection as an unnecessary restraint on trade. See Design Protection Hearings 1960, supra note 115, at 19 (letter from Lawrence E. Walsh, Deputy Attorney General). Id. at 85-88 (address by Mayers, counsel to General Electric Co.).

The motion picture industry, and especially Walt Disney Productions, organized the effective lobby against S. 2075. Spokesmen for Disney included Franklin Waldhein (whose articles are cited supra at note 201) and Ellis Amall, former Governor of Georgia, President of the Society of Independent Motion Picture Producers of California, and Regular Counsel for Walt Disney Productions; see supra notes 273, 280. Herman Talmadge, U.S. Senator froin Georgia, mtroduccd an opposition bill, S. 2852, which becaine the basis for the compromise bill, S. 1884, accepted by the Copyright Office in 1961. See infra text accompanying notcs 295-332; see also Design Protection Hearings 1960, supra note 115, at 29-30 (personal appeal froin Walt Disney to the Committee).

The Register of Copyrights recognized three sources of opposition in 1960: 1) "confirmed and irresponsible design pirates"; 2) "certain large firms whose business is not traditionally related to designs or who 'slop' the creations of their smaller and often more original competitors, trusting to their greater selling power, size, and trade names . . . to protect their interests"; 3) "a few concerns who would like . . . to have their cake and eat it, that is, to have the benefit of a new sui generis design law where appropriate but at the same time to retain the unrestricted long term of the present copyright law." Id. at 58 (testimony of Arthur Fisher).

293. See Latman, supra note 169 , at 284-85.

294. Design Protection Hearings 1960, supra note 115, at 66 (testinnony of Arthur Fisher). 
4. A Continuing Theory of Dissociation. The Copyright Office wanted a design bill enacted without delay; to achieve this end, it was willing to coinpromise with the critics of S. 2075.295 New bills introduced im Congress in 1960 attempted to "provide for effective and equitable design legislation but [to] do so without maiming copyrights."296 Under these bills, typified by S. 1884, an ornamental design of a useful article would not autoinatically be subjected to the design law and precluded from copyright law. ${ }^{297}$ Proprietors could still invoke the separability criterion of the 1959 regulation to qualify a design as a work of art protectible under section 5(g) of the Copyright Act of 1909.298

The bold attempt of S. 2075 to make "a clean break" 299 was thus modified by official endorsement of the Italian principle of dissociation, despite the misgivings this principle had earlier engendered. ${ }^{300}$ As a result, if it were possible to dissociate the concept of art in the design from the industrial character of the article, the design would not necessarily be subject to the pending design bill, S. 1884, and would remain

295. See, e.g., Design Protection Hearings 1960, supra note 115, at 22 (letter from Mumford), 80-81 (testimony of Latman), 65-66 (testimony of Fisher). A deal had already been struck with the garment industry, which was excluded from the design bill. This deal was considered mdispensable to early passage of the bill. See, e.g., REGISTER's REPORT 1961, supra note 45, at 13; REGISTER's DRAFT REPORT 1975, supra note 36, at 22.

296. Latman, The New Design Protection Proposals Before Congress, 8 Bull. Copyright Soc'Y 356, 356 (1961). The bills, now known as the Hart Bill, were S. 1884, 87th Cong., 1st Sess. (May 16, 1961) (Hart-Wiley-Talmadge Bill); H.R. 6776, 87th Cong., 1st Sess. (May 3, 1961) (Flynt Bill); H.R. 6777, 87th Cong., 1st Sess. (May 3, 1961) (Ford Bill). Register's RePORT 1961, supra note 45 , at 13 .

297. S. $1884 \S 27(\mathrm{~b})$, Design Protection Hearings 1961, supra note 21, at 8.

298. This was never established in a written provision of S. 1884. Instead, it was accomplished by statements of the interested parties, sucl as Register of Copyrights Abraham Kaminstein and Ellis Amall, representing Walt Disney, to the effect that Mazer $v$. Stein as interpreted in the past by the Copyright Office would contimue in full force after the adoption of the design bill. Because Regulation Section 202.10 (c), as amended in 1959, was said officially to interpret Mazcr v. Stein, the deal that the opposition thought it was making was essentially to retain the status quo as to copyright law. See, e.g., Design Protection Hearings 1961, supra note 21, at 153 (statement of Register Kaminstem); id. at 24 (statement of Ellis Arnall, representing Disney); $i d$. at 163-64 (testimony of George D. Cary, Deputy Register). This primciple was reiterated in REGISTER'S REPORT 1961, supra note 45, at 13-15.

The 1965 Register's Report declared only that "copyright in a pictorial, graphic, or sculptural work will not be affected if the work is employed as the design of a useful article." SUPPLEMENTARY REPORT OF THE REGISTER OF COPYRIGHTS ON THE GENERAL REVISION OF THE U.S. COPYRIGHT LAW, 89th Cong., 1st Sess. 47 (1965), reprinted in 4 Omnibus Copyright Revision Legislative History (1976)(prepared for the House Committee on the Judiciary) [hereinafter cited as REGISTER'S REPORT 1965]. No further mention of the separability doctrine is made in the 1965 report. To the extent that the Copyright Office had acquiesced in the separability criterion after 1961 , its acquiesence was implemented only in the contimuation of Regulation Section 202.10(c) as amended in 1959. See infra text accompanying notes 615-20.

299. Design Protection Hearings 1960, supra note 115, at 80 (testimony of Alan Latman).

300. See REGISTER's REPORT 1961, supra note 45, at 13-15; Waldheim, New Design Bill, supra note 201, at 359; supra text accompanying note 233 . 
entitled to full copyright protection even if embodied in a useful article. ${ }^{301}$ Only if a work of art subsisting in copyright were embodied in a useful article and then voluntarily registered under the proposed design law would its copyrightability terminate as agamst other useful articles by virtue of the substitute scheme. ${ }^{302}$

This strategic retreat in 1960 was accompamed by a series of defensive measures that could have diminished the magnitude of the compromise the Copyright Office had been obliged to accept. One measure, quickly discarded, would have excluded many designs from copyrightability by elevatimg the standard of originality required of all works to "an appreciable amount of creative authorship." 303 A second measure was the decision that useful articles should no longer be acceptable for deposit at the Copyright Office. ${ }^{304}$ In the past, the act of deposit obliged the Copyright Office to undertake an imdependent assessment of the copyrightability of the design of a useful article claimed to be a work of art. ${ }^{305}$ In the future, those seeking to copyright ornamental designs of useful articles would have to submit the request for registration in two-dimensional, "disembodied" form, that is, in the

301. Waldheim, New Design Bill, supra note 201, at 359.

302. S. 1884 \& 32, Design Protection Hearings 1961, supra note 21 (which proposes amendments to the Copyright Act of 1909).

303. Regulation Section 202.10 (b) had always required that "in order to be acceptable as a work of art, the work unust embody some creative authorship in its delineation or form." See supra note 199. The Register's Report of 1961 attempted to make the standard for all works of authorship more stringent. REGISTER's REPORT 1961, supra note 45, at 9. This elevation of the originahity standard to a point nearer the novelty standard of patent law (as desired by Justice Douglas in Lee v. Runge, 441 F.2d 579 (9th Cir.), cert. denied, 404 U.S. 887, 890 (1971)(Douglas, J., dissenting)) was out of step with the United States copyright tradition of Justice Holınes, see Bleistem v. Donaldson Lithographing Co., 188 U.S. 239, 250 (1903), and Judge Jerome Frank, see Alfred Bell \& Co. v. Catalda Fine Arts, 191 F.2d 99, 102 (2d Cir. 1951).

The Register's "creation" clause did not reappear in PReLiminary Draft for Revised U.S. Copyright LAW AND Discussions and Comments on the DRAFT, issued by the Committee on the Judiciary of the House of Representatives, 88th Cong., 2d Sess. (July 20, 1964), reprinted in 3 OmNibus Copyright Revision Legislative History 1964 [hereinafter cited as CLR PrelimiNARY DRAFT AND COMMENTS 1964]. But see 17 U.S.C. § 102(a) (1982)("works of authorship"); Reichman, After the Copyright Act, supra note 65, at 297-350 (partial cumulation in the Second Circuit).

304. S. 1884, Design Protection Hearings 1961, supra note 21, proposcd the following amendment to the Copyright Act of 1909: "a useful article shall not be accepted for deposit in the Copyright Office even if it embodies a pictorial, graphic, or sculptural work, but nothing in this subsection shall preclude deposit and registration of pictorial, graphic, or sculptural works that portray useful articles or that are intended for utilization in the designs of useful articles." Id. § 33(a); see also REGISTER's REPORT 1961, supra note 45, at 65.

305. "Expansion of administrative jurisdiction to art, including commercial and industrial art, has resulted not only in the deposit of cumbersome items but in difficult interpretative questions. It is generally behieved that the Copyright Office should not be called upon to determine these ques. tions." Latman, supra note 296, at 357 (einphasis added). 
form of drawings, sketches, or photographs portraying the articles in question. ${ }^{306}$

The Copyright Office then tried to use a line of cases devolving from Baker v. Selden ${ }^{307}$ to erect another barrier to full protection under the 1909 Act. Under these cases, the copyright in a sketch or photograph of a useful article protected only the sketch or photograph, not the manufactured version of the article it portrayed. ${ }^{308}$ This inaneuver would have forced courts, rather than the Copyright Office, to inake decisions concerning copyrightability, but only after an alleged infrimgement of the design of the useful article portrayed in the deposited photograph or drawing had occurred. ${ }^{309}$ Such decisions would have

306. The definition of a useful article became critical because the proposals denied deposit to useful articles. The definition in section 1(b)(2) of S. 1884 is essentially the same as that of S. 2075, although more clumsily drafted. See S. 1884, Design Protection Hearings 1961, supra note 21, at 2; see also supra note 249.

The Prehiminary Draft of 1964 retained the broad definition of S. 2075 and refined the provision as a whole in $\S 9(\mathrm{~b})$ :

A useful article is an article which im normal use has an intrinsic utilitarian function that

is not merely to portray the appearance of the article or to convey information. An

article which normally is a part of a useful article shall be deemed to be a useful article.

CLR Preliminary DRAFt and Comments 1964, supra note 303 (emphasis added).

Under this definition the Copyright Office did not have unlimited power to ordain deposit of designs and models by means of pictures or drawings. But neither the two-dimensional fabric design on fabric nor the Balinese dancer with an electric socket on it were directly depositable, even if works of art, because they were useful articles. Latman, supra note 296, at 357.

307. 101 U.S. 99 (1880).

308. REGISTER's REPORT 1961, supra note 45, at 14; Latman, supra note 296, at 357; see also REGISTER's REPORT 1965, supra note 298, at 48 (citing cases through 1964). This line of cases mcluded: Pic Design Corp. v. Sterling Precision Corp., 231 F. Supp. 106 (S.D.N.Y. 1964); De Silva Constr. Corp. v. Herrald, 213 F. Supp. 184 (M.D. Fla. 1962); Kashins v. Lightmakers, Inc., 155 F. Supp. 202 (S.D.N.Y. 1956); Fulmer v. United States, 103 F. Supp. 1021 (Ct. Cl. 1952); Muller v. Triborough Bridge Auth., 43 F. Supp. 298 (S.D.N.Y. 1942); Jack Adelınan, Inc. v. Sonners \& Gordon, Inc., 112 F. Supp. 187 (S.D.N.Y. 1934); National Cloak \& Suit Co. v. Standard Mail Order Co., 191 F. 528 (S.D.N.Y. 1911); Lamb v. Grand Rapids School Furniture Co., 39 F. 474 (W.D. Mich. 1889).

Another line of cases (mainly protecting dolls modeled after comic strip characters) also existed. This other line of cases included: Fleischer Studios, Inc. v. Ralpha Freundlicl, Inc., 73 F.2d 276 (2d Cir. 1934); King Features Syndicate v. Fleischer, 299 F. 533 (2d Cir. 1924); Jones Bros. Co. v. Underkoffler, 16 F. Supp. 729 (M.D. Pa. 1936), final decree entered, 24 F. Supp. 393 (M.D. Pa. 1938).

There had been no attempt to create by design legislation " any additional rights or protection' under the Copyright Law." Latman, supra note 296, at 357. Hence the sketch of a dress or an automobile and the photograph of a lamp would afford no protection to the article portrayed. Id. ; REgISTER's RePORT 1961, supra note 45, at 13-15.

309. The evidence as of 1961, although not unequivocal, suggests that the Copyright Office would have interpreted the definition of useful article expansively so as to force as many depositors as possible to use photographs or drawings. See Design Protection Hearings 1961, supra note 21, at 152 (statement by Register Kaminstein); but see id. at 163-64 (testimony of Deputy Register Cary).

Failure to adopt S. 1884, including section 32, left the Copyright Office in the position of determming whether three-dimensional models offered for deposit were "works of sculpture," and therefore directly depositable, even if useful articles. Indeed, the Deputy Register eventually 
rested initially, not on an assessment by the Copyright Office of whether the design in question was a work of art, but rather on the precedents that declined to protect useful articles manufactured from copyrighted catalogues or drawimgs. The policy underlying these cases was to prevent manufacturers from circumventing patent law; courts citing them could avoid distmguishing art from non-art at all. ${ }^{310}$

The Copyright Office now claimed that the legal rule for which this line of cases stood was obscurely expressed. ${ }^{311}$ Accordingly, the Register formulated his own interpretation of the rule in what later became section 9(a)(1) of the Preliminary Draft of the General Revision of Copyright Law in 1964: "Copyright in a work that portrays a useful article as such, such as a drawing, nodel, or photograph of the article, shall not include any right to prevent the making, distribution, or exhibition of useful articles of the design so portrayed." 312

The broad language of this provision, put forward as a clarification of existing law, could well have strengthened the exclusionary effects of the precedents on which it formally rested. Certain subject inatter categories recently accorded copyright protection as "works of art," including dolls, toys, and costume jewelry, might now be "useful articles" within the broadened definition of this term in section 9(b) of the Preliminary Draft. ${ }^{313}$ If so, these objects would fall within the new

agreed, under pressure, that the Office would have some discretion to accept direct deposits of useful articles that were also works of art. See Design Protection Hearings 1961, supra note 21, at 162 (testimony of Cary); see also S. $776 \S 32,88$ th Cong., 1st Sess. (1963), reprinted in 109 CoNo. REc. 23,653 (1963) (permissive language of the Hart and Talmadge Bill).

310. See cases cited supra note 308. But see, e.g., King Features Syndicate v. Fleischer, 299 F. 533 (2d Cir. 1924); Jones Bros. Co. v. Underkoffler, 16 F. Supp. 729 (M.D. Pa. 1936)("the other line of cases," supra note 308 ).

311. Although the policy behind these cases seemed clear, the Supreme Court in Baker v. Selden, 101 U.S. 99, 103-04 (1880), had expressly excluded works of art from the scope of its decision. Professor Latman reads the mam line of exclusionary cases derived from Baker $\boldsymbol{y}$. Selden as standing for the idea-expression dichotomy. Latman, supra note 9, at 284. Even this distimction as applied in the cases was "not easy to explain and will undoubtedly continue to be explored in the context of graphic and sculptural works" in view of the exception for dolls made froin comic strip characters. Id; see supra note 308 .

Analysis of these cases, at least as they bear on apphed art, suggests that, if a work such as a comic-strip figure is copyrightable in its two-dimensional representation, it does not forfeit this copyrightability when transposed to another medium, such as a three-dimensional doll, so long as works in the new medium have not been denied copyright protection on other grounds. The representation in two-dimensional form of an item that would not normally be copyrightable as a threedimensional model will not succeed in securing a copyright valid agamst reproduction in threedimensional form of the model thus represented. III).

312. CLR PRELIMINARY DRAFT AND Comments 1964, supra note 303 , $\$ 9(a)(1)$, at 7 (part

313. The result was not certain under the changed definition of "useful article."

[I]s a doll which is used to quiet a crying baby something which has an intrinsic utiktarian function? Do not doll manufacturers propose to attempt registration of their designs 
rule of the Copyright Office that prohibited direct deposits of "useful articles." 314 When indirectly deposited in the form of drawings, sketches or photographs, the designs of useful articles became subject to section 9(a)(1) of the Preliminary Draft, which denied "any right to prevent the making, distribution, or exhibition of useful articles of the design so portrayed." Moreover, the broad language of section 9(a)(l) as drafted allowed for no exceptions. ${ }^{315}$ Given the expected adoption of a special design law and the avowed pohicy of forcing as many designs of useful articles as possible to seek protection there, the Copyright Office could by this means quite plausibly have persuaded courts to cut back on the copyrightability of borderline subject matter. ${ }^{316}$

Such narrowing of copyright protection violated the spirit of the concessions made earlier. ${ }^{317}$ If the Register's proposed section 9 stood as drafted, and if it were imterpreted to overrule the decisions protect-

under the design bill? How would this affect dolls? For that matter, does a watch do nothing more than convey information? . . . We say this definition of "useful article" has serious problems.

Testimony of Rep. Levitas, Transcript of Meeting on Prellminary Draft for Revised U.S. COPYRIGHT LAW: Discussions of Sections 9 THRough 13, April 11, 1963 [heremafter cited as CLR Discussions of Sections 9-13, 1963] in CLR Preliminary DRAFt and ComMENTS 1964, supra note 303, at 191; see supra note 270; infra note 341 and accompanymg text.

314. See supra text accompanying notes 304-06.

315. There was no express exception even for cartoon characters, inuch less for ornamental designs "addressed to the taste," an exception acknowledged in Baker v. Selden, 101 U.S. 99, 103 (1880). The exception recognized in Baker $v$. Selden, however, begs the question posed by modern, functional design, which exerts pressure on the border with patent law.

316. Limiting the copyrightability of subject matter that had crept into copyright law before the Copyright Office had begun to develop its position in 1956 would have been consistent with the pohcy stated by Register Arthur Fisher in 1960. See Design Protection Hearings 1960, supra note 115, at 61, 63, 66 (testimony and statement of Arthur Fisher). The acquisition of copyright protection for borderline items immediately after Mazer gave industries that had been seeking special design protection more than they had asked for. Hearings 1975, supra note 169, at 993 (testimony of Latınan).

317. Oppouents were quick to point this out. At a meeting in the Library of Congress to consider the Preliminary Draft, Mr. Levitas, who was representing Walt Disney Productions, declared: "we question whether or not the attempt in Section 9(a) and particularly in 9(a)(1), actually carries out the Register's Report [of 1961]." The Register's Report, as Ms. Ringer read it, expressly said that the revision "should not alter the existing case law." CLR Discussions of SECTIONS 9-13, 1963, supra note 313, at 190. Levitas also stated:

[A]lthough we are in complete accord with the principle expressed in the Register's Report, we are opposed to the embodimeut of that principle and the way it is attempted in section 9(a)(1). Section 9(a)(1) in effeet proposes a cut-back on the scope of the copyright in a pictorial, graphic, or sculptural work and it attempts to do it by a definition which, we think, involves difficult language, and which could be subjected to many interpretations by the courts.

Id. at 189 (emphasis added).

Ms. Ringer's disclaimer on behalf of the Copyright Office is not convincing. See id. at 193. Disney's represeutatives may have correctly surmised the thrust of $\S 9(a)(1)$ and $\S 9(b)$. 
ing the "Betty Boop" and "Sparkplug" doll designs, 318 then competitors of Walt Disney Productions might have been able to manufacture their own three-dimensional inodels froin an original two-dimiensional comic strip character, although they might not have remained free to copy Disney's three-dimensional models. Even if this result were avoided by an interpretation of section 9 favorable to Disney, ${ }^{319}$ manufacturers of dolls, toys, jewelry, and other items risked uncertainty and very possibly a diminished scope of protection when S. 1884 or its successor was finally coinbined with the General Revision of Copyright Law. With life plus fifty years to be the normal duration under this law, and with the Copyright Office trying to hold its line, public policy might seein to favor the redirection of the maximum number of designs of useful articles to the law affording the shorter term of protection. ${ }^{320}$ Although manufacturers could avoid the uncertainties of copyright protection by directly registerimg their designs under the pending design laws, ${ }^{321}$ the protection obtained there would lapse after five or, at inost, ten years. ${ }^{322}$ Voluntary registration under the design law would

318. See, for example, the line of cases upholding the exclusive right of the proprietors of copyrighted cartoon strips to make three-dimensional dolls from the characters portrayed, such as Fleischer Studios, Inc. v. Ralpha Freundlich, Inc., 73 F.2d 276, 278 (2d Cir. 1934)(Betty Boop) and King Features Syndicate v. Fleischer, 299 F. 533, 538 (2d Cir. 1924)(Sparkplug). These cases are difficult to reconcile with the main line of cases cited supra note 308. At the Design Protection Hearings of 1961, Disney's representatives had taken it for granted that the Sparkplug and Betty Boop exceptions would continue to be respected. See supra note 298 and accompanying text.

319. If Disney succeeded in registering its own models as "sculptural works" on the theory that the "separated" two-dimensional Mickey Mouse had simply been incorporated within the doll, Disney could, in principle, have protected its own model in copyright law. At the 1963 meeting, the Copyright Office obliquely suggested that this route was open. CLR Discussions of SECTIONs 9-13, 1963, supra note 313, at 193 (comment of Ringer); see also REGISTER's REPORT 1961, supra note 45, at 14. If a coinpetitor had invoked section 9(a)(1) to copy the two-dimensional figure because it resembled useful articles in commerce, Disney might have replied that the deposited cartoon did not portray a useful article as such, hence it was expressly excluded from section 9(a)(1) (because it was not the design of a useful article). See CLR Discussions of SECTIONS 9-13, 1963, supra note 313, at 193 (comment of Ringer).

320. See infra text accompanying notes 596-624.

321. Manufacturers seeking to avoid the snares of section $9(a)(1)$ could contend that their works were not designs of useful articles at all, or that, if useful articles, the artistic elements of the designs were separable and capable of independent existence withm the meaning of Regulation Section 202.10(c). Manufacturers who failed to register under the design law in the hope of obtaining copyright protection on the basis of "separability," however, would run the risk of forfeiting all protection, as occurs in Italy. See infra text accompanying note 411.

322. The term of the 1959 proposal was five years, see S. $2075 \S 5$, supra note 158; S. 1884 proposed an inital term of five years plus a renewal term of five years, see S. $1884 \S 5$, supra note 296. Duration was not a major issue in the United States (although Register Fisher had prcferred a tenn of five years only); but a duration of fifteen years became the nonn in the European Coinmunity after the otherwise unsuccessful revision of the Hague Arrangement of November 28, 1960. Duchemm, supra note 71 , at 181. This was the result of "an international compromise" 
have terminated any claim to copyright protection, notwithstanding the "anti-maim" rule accepted in $1960 .{ }^{323}$

The subtlety of these defensive measures did not catch the opposition off guard. As new pressures were exerted against section 9(a)(1) of the Prelimmary Draft, ${ }^{324}$ the Copyright Office found it expedient to compromise once agam. Still optimistic that a special design bill could be enacted promptly if serious opposition were forestalled, ${ }^{325}$ the Register, in 1965, reiterated that "copyright in a pictorial, graphic, or sculptural work will not be affected if the work is employed as the design of a useful article, and will offer protection against unauthorized reproduction of the work in useful as well as non-useful articles." 326 The design bills then pending in Congress were revised to einbody the same principle, and the Copyright Office was "in full accord with it." $327 \mathrm{Re}$ sponding to criticism of section 9 in the Preliminary Draft, the Register acknowledged that atteinpts to restate "the rather difficult theoretical concepts" of the Baker v. Selden precedents in statutory language had proved "abortive." 328

In theory, the Register might still have reformulated his earlier restatement to define and limit an express exception to the principle of section 9(a)(1) for designs that "appealed to the taste" or that otherwise constituted "works of art." But this would only have reopened the

rather than a reasoned decision. Cohen Jehoram, supra note 21, at 25; $c$. infra text accompanying notes 374-76 (effects of four-year term in Italian design law).

323. S. $1884 \S 32$, supra note 296 (proposing amendments to the 1909 Act).

324. See supra note 317.

325. REGISTER'S REPORT 1961, supra note 45, at 7. Passage of the design bill was expected during the 87th session of Congress. CLR Discussions of SECrions 9-13, 1963, supra note 313, at 194 (comment of Levitas). After hearings in 1960 and 1961 on earlier versions of the design bill, the full Senate Judiciary Committee had reported it favorably on July 12, 1962; this bill (S. 1884) passed the Senate on July 23, 1962. In the 88th Congress, the Senate, without further hearings, passed the bill (now S. 776) on December 6, 1963. The House Subcommittee on Patents, Trademarks and Copyrights of the House Judiciary Committee held a hearing concerning this bill (H.R. 5523, H.R. 769, H.R. 323 [S. 776]) on December 12, 1963. Unfortunately, the transcript of these important hearings was never reprinted. See REGISTER's DRAFT REPORT 1975, supra note 36, at 13 (testimony of Latman). An earlier "hard-won compromise" concerning the exclusion of the shape of wearing apparel from the design bill was later said to have been the reason "why there has been no opposition to the bill simce 1969, other than the traditional opposition of the Department of Justice." REGISTER's DRAFT REPORT 1975, supra note 36, ch. VII, at 22. But see Statement of the Nat'l Retail Merchants Ass'n on the Subject of S. 776, now Before the SubComm. of the House Judiciary Comm., Jan. 14, 1964, reprinted in Dulin, supra note 16, at 365-70 (1965). The NRMA became a powerful opponent.

326. REGISTER'S REPORT 1965, supra note 298 , at 47-48.

327. Id. This was embodied in the 1965 Revision Bill, $\S 111$ (a), id. at 202. The pending design bills were H.R. 450 (Ford), H.R. 3366 (Flynt), and S. 1237 (Talinadge and Hart), 89th Cong., 1st Sess. (1965). See, e.g., S. 1237 § 32, Design Protection Hearings 1965, supra note 114, at 8-9.

328. REGISTER's REPORT 1965, supra note 298, at 48 ("we lave been unable to find any statutory fornulation that would express the distinction satisfactorily"). See the formulation suggested supra at note 311 . 
question of what is or is not a "work of art" under the rule governing three-dimensional useful articles inanufactured from copyrightable two-dimensional drawings or photographs. This in turn might have undermined the settled, if imperfectly rationalized, precedents that guarded the line of demarcation between copyright law and patent law, with the paradoxical result that the reformulated copyright law might have protected more articles manufactured from works that portray useful articles than had been possible in the past. ${ }^{329}$

For this and other reasons, the Copyright Office preferred to abstam from further attempts to restate the principle embodied in section 9(a)(1) of its Preliminary Draft. Announcing that "the real need is to inake clear that there is no intention to change the present law with respect to the scope of protection in a work portraying a useful article as such," 330 the Copyright Office accordingly agreed under pressure to replace the bold language of section 9(a)(1) with section 111(a) of the 1965 Revision Bill, an avowed attempt to freeze the law:

This title does not afford, to the owner of copyright in a work that portrays a useful article as such, any greater rights with respect to the making, distribution, or exhibition of the useful article so portrayed than those afforded to such copyrighted works under the law in effect on Deceinber 31, $1966 .^{331}$

To drive the poimt home, the Register pointed out that "the distinctions in this area einerge from two lines of cases," all of which he duly proceeded to list. 332

329. For a startling illustration of how a slight revision of copyright law allowed similar precedents to be undermined in the United Kingdom, see supra note 132. Another problem was that the proposed design law and the copyright law, once revised, were to share a common definition of "useful article." See infra note 331. It was counterproductive to allow the question of determining the nature of a protectible work of art to be reopened precisely at the delicate juncture where the two laws were to mesh. The United States authorities held on to settled law.

330. REGISTER'S REPORT 1965, supra note 298, at 48.

331. 1965 Revision Bill \& 111(a), REGISTER'S REPORT 1965, supra note 298, Comparative Table, App. B. Compare § 113(b) of the 1976 Act, 90 Stat. 2541, 2560 (codified at 17 U.S.C. § 113(b) (1982)). The suggestion to freeze the law was launched by Disney's representative at the 1962 meeting. See CLR Discussions of Sections 9-13, 1963, supra note 313, at 189-90 (comment of Levitas).

The Register also adopted the "carefully drafted and thoroughly considered definition of 'useful article" " mcorporated in the pending design bills: "an article having an imtrinsic utilitarian function that is not merely to portray the appearance of the article or to convey information." REGISTER'S REPORT 1965, supra note 298, at 47. Compare 1965 Revision Bill \&111(b), ReGisTER'S REPORT 1965, supra note 298 with S. 1237 \& 1(b)(1), 32(e), Design Protection Hearings 1965, supra note 114, at 2 and $\S 101$ of the 1976 Act, 90 Stat. 2541, 2544 (codified at 17 U.S.C. $\$ 101$ (1982)). The copyright revision bill and the design bills thus continued to mesh by means of a shared definition of useful articles.

332. REGISTER'S REPORT 1965, supra note 298, at 48 n."; see also supra note 308. Professor Brown termed the solution adopted in $\S 111$, the forerunner of the present $\S 113$, a "cop out." $B$. KAPLAN \& R. BROWN, supra note 245 , at 162. 
The new compromise did not destroy all of the advantages offered by S. 2075 in 1959. Even with the "anti-maim" rule and the criterion of separability, which would presumably continue to govern copyrightability under Regulation Section 202.10(c), the inodified regime could afford more protection to more designs than the law as it had evolved since 1909. The proposed scheine also recognized that some ornamental designs of useful articles could be works of art, in contrast to S. 2075, which would have kept commercially exploited ornamental designs out of copyright. The new scheme thus ended the prospect that the United States would adopt an isolated (if, perhaps, rather advanced) position on design protection and meant instead that the United States would fall in line with one of the three basic positions taken by nembers of the Berne Union, and the European Community, since 1948.333

The package deal of 1965 traded short-term protection of all creative designs of useful articles for the "illogical" results that followed when the criterion of scindibiltd was used to distinguish between copyrightable works of art granted long-term protection and ornamental designs to be given only short-term protection. ${ }^{334}$ Regulation Section 202.10(c) would continue to discriminate between inodern industrial art, in which form followed function, and traditional industrial art, in which embellishments were added to the useful article.335 Copyright registration would remain available for Mickey Mouse printed on a Tshirt, and for the design of a spoon handle in the shape of the Eiffel Tower, but not for unornamented shapes of spoon handles, lamps, or chairs. ${ }^{336}$

Administering the separability doctrine of the nodified proposal presented other difficulties. Any three-dimensional design of a useful article could be sent for registration as a sculptural work, and rejection

333. See supra notes $127-35,258-73$ and accompanying text. In a 1961 article, Waldheim correctly identified the separability test with the formal position of Italian law. See Waldheim, $\mathrm{New}$ Design Bill, supra note 201, at 359 . The article neglected to mention, however, that Italian courts were unwilling to recognize designs actually embodied in useful articles, including most twodimensional designs, as legally separable. See infra text accompanying notes 403-12.

334. See supra text accompanying note 233. But see Design Protection Hearings 1960, supra note 115, at 22 (letter from L. Quincy Mumford, Librarian of Congress)(Mumford considered the separability test workable).

335. For the curious turn of events that finally induced Barbara Ringer, as Register of Copyrights, to persuade Congress to write the separability criterion imto the Copyright Act of 1976, see infra text accompanying notes 625-38.

336. REgISTER's REPORT 1961, supra note 45, at 13-14; Latman, supra note 296, at 357; Present Design Protection, supra note 48, at 139-40. 
by the Copyright Office could be challenged in the courts. ${ }^{337}$ Indeed, the Copyright Office expected that controversial claims in the design area would "continue to grow," 338 especially after the Sears-Compco decisions of 1964 , which attempted to eliminate protection under the misappropriation doctrine of state unfair competition law. ${ }^{339}$ Another problem, barely perceptible during this period, was the doctrine of "conceptual separability." 340

More immediate administrative probleins were raised by borderline subject matter that the Copyright Office had failed definitely to exclude under either S. 2075 or section 9(a)(1) of the General Revision as first drafted. Designs of costume jewelry and toy dolls given copyright protection after Mazer $v$. Stein might or imght not become designs of "useful articles" after 1965 depending on the interpretation courts would give this tern. ${ }^{341}$ If courts held three-dimensional designs of dolls and jewelry to be "useful articles" subject to the separability criterion, such designs imight be found "separable" and "capable of independent existence." 342 If inseparable, two-dimensional drawings of the same items might still be deposited. By analogy to the precedents that protected dolls made from cartoon characters, these three-dimen-

337. This had presented the "principal administrative problem" in the past. REGISTER's REPORT 1961, supra note 45, at 13. By the time of the 1965 General Revision Bill, supra note 331, the Copyright Office had agreed to consider accepting direct deposits of some designs of useful articles once again if they might qualify for protection under the separability test of Regulation Section 202.10(c). See the permissive language in S. 1237, \& 32, Design Protection Hearings 1965, supra note 114 , at $8-9$.

338. REGISTER'S REPORT 1961, supra note 45, at 12.

339. Compco Corp. v. Day-Brite Lighting, Inc., 376 U.S. 234, 237 (1964); Sears, Roebuck \& Co. v. Stiffel Co., 376 U.S. 225, 231-32 (1964); see Letter from Sylvan Gotshal, Design Protection Hearings 1965, supra note 114, at 67-68 (the Sears-Compco decisions had made "sharp inroads on the scope of judicial protection . . . offered to the victims of the design pirate"). Professor Derenberg behieved that, after Sears-Compco, passage of the pending design bills had become "imperative." Derenberg, in Product Simulation: A Right or a Wrong, 64 Colum. L. Rev. 1178, 1192, at 1200 (1964); see infra text accompanying notes 532-37.

340. See supra note 218 . The doctrine of conceptual separability can pose hard questions for dissociation theory in imdividual cases. See infra notes 407-11, 546-47 and accompanying text; see also Reichman, After the Copyright Act, supra note 65, at 324-33 ("The Two Sides of Conceptual Separability").

341. Asked whether "a borderline area" would continue to exist "between works of art . . . covered by copyright and useful articles that will be covered by design," a spokesman for the Copyright Office answered in the affirmative. "Take dolls, or . . . jewelry, for example. Jewelry may be a work of art or . . . some pieces of jewelry might well be useful articles. Or . . . even ... a nonfunctional piece of jewelry may be a useful article by its very nature. . . . It depends upon your outlook. I think these are borderline areas." Design Protection Hearings 1961, supra note 21, at 163 (testimony of George D. Cary).

The Copyright Office and the courts continued to treat designs of toys, dolls, and jewelry as copyrightable "works of art" while the design bills were pending. For the situation after 1976, see Reichman, After the Copyright Act, supra note 65.

342. See infra notes $467-70,520$ and accompanying text. 
sional designs could qualify for long-term copyright protection under section 111(a)(1) of the General Revision Bill of 1965,343 although other highly creative functional designs could obtain only ten years of protection as a result of the main line of cases devolving from Baker $v$. Selden. ${ }^{344}$

By 1965 , the Copyright Office had thus succeeded in completing steps one and two of its original timetable ${ }^{345}$ but at the cost of major concessions to the protectibility of ornamental designs in copyright law, made despite the economic arguments agamst such concessions. ${ }^{346}$ Moreover, administrative difficulties known to inhere in Regulation Section 202.10(c) of 1959 would remain. ${ }^{347}$ On the positive side, the package deal as it stood in 1965 retamed the dual regime of design protection below the line of demarcation with copyright law that was its most distinctive feature. ${ }^{348}$ Further, the Copyright Office had man-

343. Courts might have held that the designs of dolls, jewelry, and toys were not designs of useful articles at all because they lacked any utilitarian function or because their sole utilitarian function was "merely to portray the appearance of the article." 1965 Revision Bill § 111(b), supra note 331. Compare supra note 260 and accompanying text (view of Bogsch) with supra note 341 (view of Cary). For post-1976 judicial interpretations of this definition, see Reichman, After the Copyright Act, supra note 65, at 375-79.

344. 101 U.S. 99 (1880); see supra note 308 and accompanying text.

345. See supra text accompanying notes $228-30$.

346. See supra notes $284-86$ and accompanying text.

347. Two leading scholars, Professors Nimmer and Derenberg, were left dissatisfied by the current proposals. See House Comm. ON THE Judiciary, Copyright Law Revision, Part 2, Discussion AND COMMENTS ON REPORT OF THE REgIsTER OF COPYRIGHTS, 88th Cong., 1st Sess. (1963), reprinted in 3 OMNibus Copyright Revision, Part 2 [hereinafter cited as CLR DiscusSIONS AND COMMENTS 1963]. Professor Nimmer declared: "I am concerned that your limitation of 'works of art' to works which are 'nonutilitarian in themselves' might deny protection to a sculptured work if in itself it is capable of a utilitarian use, for instance, as a lamp base or as a saltcellar." CLR Discussions AND COMMENTS 1963, supra, at 372.

Equally distressed, for other reasons, was Professor Derenberg:

1 am one of those who had never been happy with the change in the definition of works of art,' which later resulted in the Stein case and which has resulted in a degradation of the concept of copyright and some rather untenable efforts to distinguish between artistic and nonartistic features of utilitarian articles.

CLR Discussions AND CoMments 1963, supra, at 275.

Compare the following remarks of Barbara Ringer, then representing the Copyright Office at the proceedings:

I would say that most of the people who commented on this part of the Report agreed with the recommendations. ...

One person argued, as a matter of principle, that the Copyright law should be extended to cover all industrial designs-that this distinction between useful articles and non-useful articles should be dropped entirely. This is the concept of unity of art that some countries follow. Another felt quite the opposite-that under no circumstances should the copyright law protect any commercial or industrial application of a work of art; that these should be dealt with in a separate act.

CLR Preliminary Draft \& Comments 1964, supra note 303, at 188 (testimony of Barbara Ringer)(emphasis added); see supra note 44.

348. REGISTER's REPORT 1961, supra note 45, at 14. In other words, the United States proposal would have rendered a high threshold for protectibility in the design law inconsistent with the 
aged to "hold the line" by keeping inost three-dimensional designs of useful articles out of copyright law while the pending design bills inoved forward to the point at which legislative enactinent becaine feasible. ${ }^{349}$

The latest coinpromises should have paved the way for quick passage of the bills theinselves. In 1964, the House Subcommittee on Patents, Trademarks and Copyrights, after hearings in late 1963, reported the design bill favorably to the full House Judiciary Committee. In 1966, after a hearing before its own Subcommittee on Patents, Trademarks, and Copyrights, the Senate passed an amended version of the bill, but no corresponding action einerged from the House. ${ }^{350}$ Then, in late 1969, in an "historic docking,"351 the Senate's Hart Design Bill was joined with the copyright bill in a new, integrated proposal. ${ }^{352}$

This proposal would have established a sui generis regime of design protection and ended the increasingly isolated position of the United States with respect not only to its OECD trading partners, but also to most of the world's industrialized countries and to leading developing countries as well. ${ }^{353}$ Moreover, prompt enactment of the design bill, now Title III of the copyright bill, would have provided the

high standard of nonobviousness in the design patent law, with which it would function as an integrated systein of design protection. Nevertheless, the exact standard of protectibility set by $\$ 2$ and 3 of S. 2075 and its progeny was and reinains uncertain. See infra text accompanying notes $582-600$.

349. See supra notes 194-95 and accoinpanying text; infra text accompanying notes 492-96. Nevertheless, a "great many of the sluunbering meinbers of the bar" were now "alerted . . . to the fact that they could get 56-year protection by copyright if they could get in as a work of art." Design Protection Hearings 1961, supra note 21, at 85-86 (testimony of Giles Rich).

350. ReGisteR's DRAFT REPORT 1975, supra note 36, ch. VII, at 13; see supra note 325; see also Design Protection Hearings 1965, supra note 114, at 14-23 (describing the supporters of the design bill including former opponents now appeased). Only the Department of Justice and the National Retail Merchants Association openly opposed the design bill during this period. Deputy Register Cary blained the Merchants Association for the failure of the House to pass a design bill in 1963, despite approval of S. 776 by the Senate. Id. at 21; see also id. at $54-62$ (statement of Latman, National Committee for Effective Design Legislation).

351. Hearings 1975, supra note 169, at 992 (testimony of Alan Latman).

352. Id. See generally Report of the CoMmittee on the JUdiciary, House of RePReSENTATIVES, H.R. REP. No. 1476, 94th Cong., 2d Sess. 50 (1976), reprinted in 1976 U.S. CoDE CoNG. \& AD. NEws 5659-801 [hereinafter cited as H.R. ReP. No. 1476 (1976)]. The bill, as reported by the Senate Subcommittee, was S. 543, 91 st Cong., 2d Sess. (Dec. 10, 1969). The design bill, incorporated in the general revision bill as Title III, later became Title II when the provisions pertaining to the National Commission on New Technological Uses of Copyrighted Works (CONTU) were removed to a separate title. REGISTER's DRAFT REPORT 1975, supra note 36, ch. VII, at 13.

353. See supra notes 114-18 and accompanying text. The United States' isolated position was attributable in part to the unwillingness of the appellate courts to uphold design patents. See supra notes 140, 244-46 and accompanying text. More generally, the role of intellcctual property in international trade had been insufficiently addressed in the United States. See Mossinghoff, The Importance of Intellectual Property in International Trade, reprinted in 26 PAT. TRADEMARK \& 
Copyright Office with a statutory basis for defending the restrictive interpretation of Mazer $v$. Stein it had established in the 1959 regulation. ${ }^{354}$ Although devised only as a temporary measure to inhibit access to copyright law pending enactment of the 1959 design bill, Regulation Section 202.10(c) was in fact mediating between copyright protection under the 1909 Act and patent protection under the Design Patent Law of 1842.355 The longer the legislative process dragged on, the longer the Copyright Office was forced to defend an anticumulationist model of the Itahan type without any functional equivalent of the special design law that is the fulcrum of the Italian system.

\section{B. The "Unity of Art" Heresy: Its Spread and Vigorous Repression.}

1. Separability Italian Style. The most striking feature of the Italian system of design protection, to the American observer, is the extent to which the Italian Design Law of $1940^{356}$ succeeds in fulfilling its goals while adhering niore closely to the patent law paradigm than any other sui generis regime within the European Community. ${ }^{357}$ Article 5 of this law confers absolute protection in the patent sense on new ornamental designs or models capable of giving "special ornamentation to specific imdustrial products, either by means of their forn, or the particular combination of lines, colors or other eleinents." 358 Designs meeting the prerequisites of novelty and quahtative originality incorpo-

CopYRIGHT J. (BNA) 546-51 (1983)(remarks of Gerald J. Mossinghoff, Commissioner of Patents and Trademarks).

354. See supra text accompanying notes 197-203.

355. Act of August 29,1842 , ch. $263, \S 3,5$ Stat. 543 ; see supra notes $227-30$ and accompanying text.

356. Supra note 96; see supra text accompanying notes 208-13.

357. Article 1 of the ltalian Design Law of 1940, supra note 96, expressly apphies the requirements of the patent law of June 29,1939 , to both utility models and ornameutal designs and models, except as otherwise expressly provided in the rest of the design law itself. The design law as a whole governs "the legislative dispositions pertaining to patents for industrial models," as the title of the Royal Decree of 25 August 1940 proclaims. Id.; Duchemin, supra note 2, at 40-41. "Industrial models" are then separated into "utility nodels," given protection under article 2 and "ornamental designs and models" protected under article 5. The general dispositions of the design law (articles 9-17) apply across the board to both utility models and ornamental designs and models. Id at 40-41. See generally G. SENA, supra note 205, at 431-49, 454-67; Benussi, supra note 48 , at $115-24$.

This attempt to include both utility models and ornamental designs and models within a single framework governed by a common legal regime accounts for the structural rigidity of the ltahan law. Id.; G. SENA, supra note 205, at 444 . The ltalian law remains quite rigid in relation to the other European Community laws. See Duchemin, supra note 71, at 175-81.

358. Italian Design Law of 1940, art. 5, supra note 96. 
rated by reference froin patent law ${ }^{359}$ nay qualify for a single term of protection that now lasts fifteen years. ${ }^{360}$ The Italian Design Law also provides for administrative screening through which compliance with substantive as well as formal prerequisites may be determined. ${ }^{361}$ It tolerates no divulgation prior to deposit, whether in Italy or abroad, ${ }^{362}$ and, alone among the relevant European Commumity laws, inandates forfeiture if rights granted are not promptly exploited. ${ }^{363}$

In practice, flexible judicial administration has tempered the structural rigidity of the Italian Design Law as applied to ornamental designs of useful articles. ${ }^{364}$ The novelty requirement, although strict with regard to prior divulgation, is otlierwise satisfled by a relative rather than an absolute measure of differentiation from the prior art. Italian case law acknowledges that industrial art necessarily draws upon preexisting design elements and caters to exigencies of contemporary style and fashion. Hence the form of an ornamental model seeking protection must differ from forms that have already been applied and exploited industrially, but not from all forms considered in the abstract. ${ }^{365}$ Courts then assess novelty in relation to the overall aesthetic effect of the object; novelty nay not be defeated by disaggregating the design into components or combinations of components anticipated by prior art. ${ }^{366}$ Even the simplification or further stylization of forms or styles in the public domain will reportedly satisfy the novelty standard if adapted to inodern tastes and not previously divulged. ${ }^{367}$

359. Z.O. ALGARDI, supra note 61, at 86-99, 104-09; M. FABIAN1, supra note 96, at 52-57; supra note 357. The requirement that a candidate design be new is also expressly stated in article 5 of the Italian Design Law of 1940 , supra note 96.

360. Italian Design Law of 1940, art. 9, supra note 96; Benussi, supra note 48, at 116. The original term of protection lasted only four years; this was changed in 1977. See supra note 215.

361. Duchemin, supra note 2, at 22-23.

362. Z.O. Algardi, supra note 61, at 104. This follows by analogy to the patent law. Id.; see supra note 357 . The government was concerned that others, besides the author, might produce the same design. Z.O. ALGARDI, supra note 61, at 105. As the level of creativity in cominercial designs diminishes, this becomes a major coucern of foreign design law. See, e.g., Ljungman, supra note 147 , at 123 .

363. The deposit must be followed by actual exploitation within one year from the date of filing, as is the case with regard to utility patents. Duchemin, supra note 2, at 22-25. Duchemm reports that "case law has proved strict in this regard." $1 d$. at 24-25.

364. Franzosi, supra note 211, at 110. "All the legislative prerequisites for the protection of ornamental designs and models correspond to those required for inventions and utility models, but the cominentators have shown that in fact these prerequisites become differentiated in certain respects." Z.O. ALGARDI, supra note 61, at 85-86 (trans.); see M. FABIANI, supra note 96, at 53 (flexibility in regard to ornamental designs), 49-50 (absolute novelty in time and space required for utility models in Italy as in the Federal Republic of Germany).

365. M. FABIANI, supra note 96, at 53-55.

366. Id at 53. An ordinary observer test is used. Z.O. Algardi, supra note 61, at 109.

367. M. FABIANI, supra note 96, at 55; see supra note 362 . The novelty standard under the Italian design law is thus roughly comparable to the novelty standard under the United States 
Similarly, the requirement of qualitative originality, which can be read as a test of inventive achievement like that governing utility patents, is apphed less rigorously to ornamental designs than to inventions. ${ }^{368}$ According to Algardi,

a rigid concept of originality would not fulfill the need to protect industrial products ... . and would in effect negate the value of the protection for ornainental models. . . . Ornainental models rarely constitute creations in the true and proper sense, they are rarely original in an absolute sense, because they generally inake use of preexisting elements. ${ }^{369}$

This relatively less stringent standard of creative content obliges the candidate design to produce a "new aesthetic effect" in the eyes of a qualified designer working in the specific product area. ${ }^{370}$ The ornamental design or model need not be characterized by a marked individual or artistic imprint; an increase in the appeal of the designer's product or "a forinal innovation even of a inodest aesthetic impact" will suffice. ${ }^{371}$ Combination designs, modifications of existing designs, even reproductions from nature, can all meet the requirement of qualitative originality if their novel aesthetic effects result from a minimum degree of personal elaboration. ${ }^{372}$

This deliberate judicial softening of the rigidities in the Italian statute of 1940 serves to implement the legislator's protective mandate

design patent statute of $1952, \S \S 171-173$, as judicially interpreted. See 1 D. ChIsUM, PATENTS \$ 1.04[2][e], at 1-127, 1-128 (1983); Pretty \& Durant, Protection for the Appearance of Useful Articles Under a Patent Approach, reprinted in 1982 ABA-SEction of PATENT, TRADEMARK AND Copyright LaW, Summary of Proceedings 196.

368. Z.O. AlGARDI, supra note 61 , at $90-91$; see supra note 364 . Originality in the patent-law sense is also referred to as "intrinsic novelty" (inventive achievement) as opposed to "extrinsic novelty" (distance from the prior art). See M. FABIANI, supra note 96, at 49-51 (utility models), 53-57 (ornamental designs).

369. Z.O. Algard, supra note 61, at 91 (trans.); accord Franzosi, supra note 211, at 110. Compare the flexibility shown by courts in the Federal Republic of Germany as reported by $H$. HubMaNN, Gewerblicher RechtsSchutz 199-201 (4th ed. 1981). But see Englert, supra note 96, at 779 (argues for strong requirement of creative achievement).

370. Z.O. AlGARDI, supra note 61 , at 90-93, 95; M. FABIANI, supra note 96, at 56. Without this flexibility, the requirement of qualitative originality derived from patent law (analogous to "nonobviousness") could constitute a formidable barrier to protectibility. Z.O. AlGARDI, supra note 61 , at $90-91$.

371. Z. O. ALGARDI, supra note 61 , at $92-93$. Sena speaks generically of a creative contribution, however. G. SENA, supra note 205 , at 460 . Prior use, in other product groups or trade areas, of the shape sought to be protected reportedly constitutes no bar to its "origimality," if the shape gives à different aesthetic result when applied to a new product. Z.O. ALGARDI, supra note 61, at $90,92$.

372. Z.O. AlGARDI, supra note 61, at 93-99; M. FABLANI, supra note 96, at 55-57. But nodifications and combimations inust be inore than trivial and not simple reproductions of known forms or mere functional juxtapositions of commonplace objects. Z.O. ALGARDI, supra note 61, at 95; M. FABIANI, supra note 96 , at 55-57. 
concerning industrial art. ${ }^{373}$ Two ancillary factors may have furthered this goal: the very short term of protection granted by the Italian Design Law as drafted in 1940, and the possibility of protecting utility models within the general legal framework it established.

The protection that articles 2 and 9 of the 1940 design law originally afforded ornainental designs lasted for a single, nonrenewable term of four years, to be computed from the date of filing for registration. ${ }^{374}$ It seeins plausible to relate the flexibility shown by the judiciary im implementing the substantive requirements of the Design Law to the knowledge that such indulgence actually protected little more than lead time. Users who complied with the strict formal requireinents of registration and deposit ${ }^{375}$ nay have elicited a certain judicial willingness to uphold exclusive rights once granted, in part because the unavailability of protection in copyright law ${ }^{376}$ meant that would-be infrimgers had only four years to wait before they could legally exploit even the most innovative design.

Of greater importance was the decision in 1940 to combime the protection of ornamental designs with that of utility models within a single statutory scheme. ${ }^{377}$ Utility models have been defined as "products of human activity and creative effort which have the characteristics of invention but do not rise to the level of technical progress or inventive height required for the grant of a patent." 378 In effect, countries that protect utility models mitigate the strictness of the requirement of considerable technical progress as a condition to a regular patent. ${ }^{379}$

373. See supra note 369 and accompanying text. The paucity of litigated cases raising the issues of novelty or qualitative originality attests to the receptivity of the Itahian design law as thus interpreted. Z.O. ALGARDI, supra note 61, at 95.

374. The brevity of this term, which was conditioned by the decision to protect utility unodels, may, over time, have restricted the contribution that ltaly's expanding design industries could make to the national economy. G. SENA, supra note 205, at 444; Benussi, supra note 48, at 124. For the extension of the period of protection to the European Community norm of fifteen years in 1977 , see supra notes 215,360 . The duration for utility models was extended to ten years. Z.O. ALGARDI, supra note 61, addendun1.

375. See supra notes 361-63 and accompanying text.

376. Article 5, para. 2 of the Italian Design Law of 1940, supra note 96, states expressly that the "provisions concerning copyright do not apply to the said designs."

377. This decision had "a profound effect" on the overall approacl to designs and models im Italian law. M.A. Perot-Morel, supra note 2, at 89-90.

378. S. LADAS, supra note 2, at 949 . Utility models, also known as "small inventions" or "petty patents," are protected in only a few countries, notably the Federal Republic of Germany, Italy, and Japan. See generally F. PERRET, supra note 2, at 188-234; S. LADAS, supra note 2, at 949-56; Perret, supra note 48, at 147-53.

379. S. Ladas, supra note 2, at 949; see 1982 ABA Sec. Pat. Trademark and Copyrioht L., 105 [heremafter cited as ABA-PTC, Proposed Law on Petty Patents] (describing the need for "a new form of intellectual property which is not subject to the vicissitudes of judicial application of Section 103," namely 35 U.S.C. \& 103 (1982)(requirmg "nonobviousness" for patentable inven- 
The scope of this derogation from patent law is ostensibly regulated by linking the technical utility function seeking protection as a utility model to "a new design arrangement or device," that is, to a specific functional innovation of shape or form. In theory, this focus on design eliminates "inventions of processes and of substances" as well as nontechnical aesthetic designs. ${ }^{380}$ In practice, the true scope of the derogation depends, first, on the extent to which the protected elements of shape are permitted by the legal system indirectly to affect other technical features of the product in question; and, second, on the level of innovation required in order to obtain protection for a specific utility function. 381

Article 2 of the Itahian Design Law of 1940 protects as utility models those novel features of form, configuration, arrangement, or counbination of parts that enhance the utility, efficiency, or functionality of industrially reproducible machines, or of tools or instruinents, or of other similar useful objects. ${ }^{382}$ Although the text of this provision could be construed broadly, it is settled-with some dissent-that the institution of the utility model in Italy "aims at a creation of form in the sense that the inventive activity is expressed in the external shape of a useful objeet and not im the techrical idea that governed its inception." 383 Italian law thus attempts to distinguish utility models from patentable inventions by emphasizing the design component. ${ }^{384}$ Article

tions); see also 27 PAT. TRADEMARK \& Copyright J. (BNA) 634, 645-48 (1984)(bills to protect semiconductor chip designs as "mask work").

380. S. LADAS, supra note 2, at 950.

381. Compare S. LADAS, supra note 2, at $949-52$ (claims that protection of utility models in Federal Republic of Germany emphasizes the technical effect produced by a given shape) with Perret, supra note 48, at 147 (claims courts in the Federal Republic have broadened subject matter by not insisting on novel effect produced by specific exterior shape). According to Perret, protection in the Federal Republic exteuds beyond the registered form "to all the equivalent configurations on the technical or utilitarian plane," including cases in which a third party is prevented from obtaining the same technical effect by dint of a different exterior design. Id. The element of shape, used to justify protection for an industrial design, may thus simply disguise a technical invention given de facto patent protection without satisfying the substantive prerequisites of the patent law. The true justification is expedience. F. PERRET, supra note 2, at 225-34.

ABA-PTC, Proposed Law on Petty Patents, supra note 379, could go even farther by dispensing altogether with any requirement of design as the protectible subject matter. It would instead protect "novel commercial products" as such, but only against copying. Id. at 105-06. An evaluation of utility models as an institution is beyond the scope of this study.

382. See Italian Design Law of 1940, art. 2, supra note 96.

383. Perret, supra note 48, at 147-48 (trans.); accord G. SENA, supra note 205, at 431-32, n.2 (trans.)(emphasis added) ("the objects of 'a patent for utility models' are essentially functional creations of form that render a given article particularly effective or convenient to use or apply, while the 'patent for ornamental designs and models' concerns aesthetic forms meant to give industrial products a special ornamental effect, or more generally, a particular formal appeal").

384. M.A. PERot-Morel, supra note 2, at 90; Perret, supra note 48, at 147-48. The industrial designer, in seeking to reconcile technological exigencies, consumer psychology, and considera- 
2 may be viewed as protecting innovative features of shape or appearance that are dictated by functional considerations ${ }^{385}$ and that, for this reason, would not normally be protected as ornamental designs or models within the meaning of article 5.386

Inclusion of the utility model rendered the Italian design statute structurally more rigid than one that protected ornamental designs alone. ${ }^{387}$ Nevertheless, so long as Itahan courts remam willing to adjust the patent-law paradigm downwards in order to accommodate industrial art, as the evidence suggests they routinely do, ${ }^{388}$ the availability of an alternative form of protection under article 2 of the Italian statute may actually have reinforced the protection of ornainental designs under article 5. The interdependence of form and function in modern industrial art teinpts manufacturers to try to circumvent the patent laws by using deposits of ornamental designs to protect technical features that might not otherwise qualify as patentable inventions.

tions of cost effectiveness with his available raw materials may produce a new and more functional shape of a useful article at a lower cost than his predecessors had been able to do. This shape, if sufficiently novel, is precisely the kind of utility function that article 2 of the 1940 design law is said to protect. G. SENA, supra note 205, at 448-49.

385. Most countries that protect aesthetic or creative designs under a special design law exclude designs in which the functional or technical component is deemed excessive. See, e.g., Uniform Benelux Designs Law, supra note 117, art. 2(1). Similarly, under the United States design patent law, "a design that is dictated by considerations of function is not a proper subject for a design patent," im part because not sufficiently "ornamental" and im part because "allowance of a design patent may grant in effect a monopoly on functional features that does not meet the normal requirements for a utility patent on a product or process." I D. CHIsum, supra note 367, \& 1.04[2], at 1-124 to 1-125. But see Nordic Design Laws, supra note 117; Smith, Droit Scandinave, reprinted in PARIS SYMposium, supra note 27, at 183, 185 (Nordic design laws permit protection of technically necessary features but literature denies that utility models are protected).

386. Article 2 attempts to clarify the line between utility models and patents for inventions at the cost of blurring the line between utility models and ornamental designs protected under the design law. Perret, supra note 48, at 148; M.A. Perot-Morel, supra note 2, at 91.

387. Some observers condemn the institution of utility models as an unwarranted derogation from the patent law in the interest of expedience that will not withstand theoretical analysis. See, e.g., F. PERRET, supra note 2, at 189-234. Nevertheless, utility models lave proved to be of great commercial value to those countries-including Japan and the Federal Republic of Germanythat have been willing to protect this form of innovation.

Disregarding the validity of utility models in theoretical terms, their technical nature led to their assimilation with the patent law. Ornamental designs were dragged along in the wake. But the technical nature of utility models nay render them inconpatible with a legal regime that also seeks to protect industrial art. Those who believe utility models are incompatible with such a regime claim that different legal imperatives govern the two subject matter categories. They stress the tensions that arise when formal and substantive prerequisites geared to technically dictated design features are also used to determine the protectibility of aesthetic designs. See M.A. PerorMOREL, supra note 2, at 89-91 (citing Italian authorities). Arguably, the decision to yoke technical and aesthetic designs together under a single, necessarily rigid, legal framework could thus have resulted in a formula for treating neither subject matter category in a satisfactory manner. Id. at 91.

388. See supra notes $364-73$ and accompanying text. 
Outside Italy, courts seeking to defend the line of demarcation with patent law may resist these pressures by excluding much industrial art from the design laws on the ground that ornamental features of shape are inseparable from functionally significant features. ${ }^{389}$ This im turn only serves to increase the pressures on copyright law. ${ }^{390}$

When utility models are linked to ornamental designs, as under the Itahan Design Law of 1940, it 1nay becoine easier to insulate both patent and copyright law from encroachment by industrial designs ${ }^{391}$ because both aesthetic and technical designs can aspire to an amalgamated form of sui generis protection. Withni this sui generis regime, which governs both utility models and ornamental designs, fears that aesthetic designs may conceal significant functional effects are largely dispelled by the capacity of the utility model to acquire protection in its own right on softer terms than patent law would otherwise tolerate. ${ }^{392}$ Moreover, Italian practice allows the owner of a design to seek both "an ornamental design patent" and "a utility model patent" at the time of registration, and to exploit the two "patents" concurrently in the same design. ${ }^{393}$ Even if the technical features of the utility model were to be invalidated, the ornamental features of the same design could remain protected. ${ }^{394}$ This fluidity in the Itahian regime arguably in-

389. G. SENA, supra note 205, at 449; Gaubiac, supra note 48, at 2-3; Perot-Morel, supra note 69, at 67-74. "This is why French law (like most legislations . . .) anticipating this risk, has made the law on patents prevail when the creation of form cannot be separated from the invention." Id. at 67 (with reference to ornamental designs otherwise protectible either in French design law or in copyright law under unity of art doctrine).

For similar tendencies in United States design patent law, see, for example, Nimetz, supra note 18, at 116-21. See also I D. Chisum, supra note 367, $\S 1.04[2]$, at 1-123 to 1-127. The utility model in disguise may be at issue in some of the double patenting cases under the United States design patent law. "Where design and utility patents cover the same invention in the sanue article . . . the later patent will be invalid under the doctrine of double patenting." Pretty \& Durant, supra note 367, at 198.

390. See, e.g., Pérot-Morel, supra note 69, at 72-73 ("hexagonal forn of the head of a car lubricator," "a folding luggage rack on a scooter," and "door hinges," held copyrightable under unity of art thesis in France); see supra note 132 (routine protection of nonartistic utilitarian designs in United Kingdorn copyright law).

391. On the importance of this objective in general, see Gaubiac, supra note 48, at 2-3; for its priority in Register Arthur Fisher's original sclieme, see supra text accompanying notes 263-71.

392. See supra notes $377-86$ and accompanying text.

393. G. SENA, supra note 205, at 449 . The two "patents" inust be applied for simultaneously and not successively. M.A. Perot-MOREL, supra note 2, at 94.

394. M.A. Perot-MOREL, supra note 2, at 93-94. The existence of a single mode of design protection, or of two mutually exclusive modes, could bar the result discussed in the text, $i d$, and force the design owner to make difficult choices of legal routes at his peril. This im turn would increase the very pressures on patent and copyright laws that special design laws are ineant to relieve. 
creases the scope of protection for ornamental designs by decreasing the fear of illicit protection for functional design features. ${ }^{395}$

Although the theoretical validity of the utility model has been challenged, ${ }^{396}$ practical advantages flow from the decision to "encompass all the aspects of form or external appearance that bear on the value of industrial products" within a single regime dedicated to the protection of industrial models. ${ }^{397}$ Articles 2 and 5 of the Italian Design Law, taken together, deliver an impressive amount of short-term design protection to those proprietors willing and able to register prior to launching their products on the market. ${ }^{398}$

It is with this larger protectionist framework in mind that one must interpret the Italian decision of 1941 to protect ornamental designs of useful articles as works of applied art in copyright law "only if their artistic value is separable [scindibile] from the industrial character of the product with which they are associated." 399 Italian courts attempting to administer this criterion without contradictory results construe "separability" to exclude most three-dimensional models from copyright law ${ }^{400}$ on the ground that their ornamental aspects, although possessed of aesthetic value, necessarily constram the expressive freedom

395. Presumably, fears of illicit protection were decreased even more when protection for either subject matter category could not exceed a bare four years of lead time. See supra notes 374-76 and accompanying text. The Italian law of imfair competition normally reduces pressure on the border with patent law by permitting manufacturers otherwise imeligible for statutory protection to seek redress against imsappropriation im a variety of cases that typically mvolve slavish imitation. But the law against slavish imitation in Italy is reportedly closed to aesthetic designs, which must obtain protection, if at all, in the design law. G. LAVILLA, IMITAzione ServiLe E FORME Di MERCATO 8 (1976); Sena, supra note 212, at 173-74; see infra note 428.

396. See supra note 387. If the analysis in the text holds true, Professor Perret's defense of "separability" as determining a universally valid line of demarcation for purposes of copyright law nay be weakened by his powerful critique of the utility model, which acts to stabilize the Italian system as a whole. Compare supra notes 220-26 and accompanying text (Perret's view of separability) with supra note 387 (Perret's view of utility models).

397. M.A. PERot-Morel, supra note 2, at 90; see also id. at 91,93 (although utility models are "second-class inventions," the Itahian regime "is not so devoid of interest as may appear at first glance")(trans.).

398. See supra text accompanying notes 361-63. But see Duchemin, supra note 71, at 184-85 (many designers cannot comply).

399. Italian Copyright Law of 1941 , art. 2(4), supra note 200 (as translated at supra note 209). Because the doctrine of scindibilta in article 2(4) of the 1941 Copyright Law, supra note 200, was codified after the Italian Design Law of 1940, supra note 96 , some commentators contend that the copyright law has tacitly overruled article 5, paragraph 2 of the design law, whicl expressly forbids cumulation between the copyright law and the design law. The courts, however, contmue to lieed the noncumulationist mandate in article 5 of the design law. Benussi, supra note 48, at 12122.

400. This avoids the zig-zag course otherwise likely to occur. M.A. PEROT-MOREL, supra note 2, at 103; Benussi, supra note 48, at 120; see supra note 226. 
of authorship within self-assumed, practical, and impersonal limits. ${ }^{401}$ The theoretical possibility that aesthetic elements of the design might so transcend the useful object as to constitute a conceptually separable work of art capable of independent existence is thus virtually nil in practice.402 On this approach, an Itahan court recently denied copyrightability to the two-dimensional design of a lady's scarf by a renowned designer on the grounds that its aesthetic qualities were appreciable only as a function of their practical utility. 403

The ambiguity inherent in the doctrine of separability induces some courts to attach undue importance to such factors as the nature of the material support, the scope of the artist's creative purpose, and the intended use of the creative work. To the extent that such factors do influence decisions, scindibiltà tends to become a euphemism for the destimation or purpose test tried and rejected in earlier Italian case law and in France. ${ }^{404}$ When, instead, serious claims to copyrightability based on conceptual separability are advanced, courts and commentators insist that conceptual separability results from a high degree of artistic value. 405 Yet such covert reliance on artistic value cannot read-

401. For the view that the normal function of industrial design is to combine aesthetic and useful qualities into an indivisible whole, see G. SENA, supra note 205, at 451. Accord F. Perret, supra note 2, at 264-67; see also supra notes 214-15 and accoinpanying text.

402. See Z.O. ALGARDI, supra note 61, at 71, 73, 77 (discussing 1974 cases involving inodernistic chairs and tables); Benussi, supra note 48, at 110 (agreeing as to shapes of useful articles); supra notes 220-21 and accompanying text. But see Z.O. ALGARDI, supra note 61, at 76 n.66 (citing 1974 decision of Milan tribunal uplolding copyrightability of a series of plastic toy figures based on original inodels created by a sculptor because they "communicate feelings and emotions").

403. Sena, supra note 212, at 172-73; see supra notes 217, 225 and accompanying text. Older decisions admitted paintings of flowers on seed packets, advertising posters, printed scarves, and sculptured candelabras to Italian copyright law as applied art. Z.O. ALGARD1, supra note 61, at 71 ; see also infra note 410 .

404. Z.O. AlGARDI, supra note 61, at 76-77; Franzosi, supra note 211, at 110; Pérot-Morel, Pavia Conference, supra note 87, at 384-85; see also supra note 220. But see F. PERRET, supra note 2, at 260-68 (judicial aberrations do not impinge upon the validity of dissociation theory). For the destination test in France, see supra notes 52-61 and accompanying text.

405. See, e.g., G. SENA, supra note 205, at 453 (citing Auletta). Ascarelli also approves of testing conceptual separability in terms of artistic strength. These and other Italian authors suggest "high and remarkable" artistic value would be a primary or even necessary determinant of dissociation. Gaubiac, supra note 48, at 56-57. Fabiani once suggested that Italian courts actually work in reverse: "having recognized the creative value of the work of applied art, they acknowledge, in general, the ideal dissociability from the industrial product" necessary for copyright law. M.A. PEROT-MOREL, supra note 2, at 203 (quoting Fabiani). Gaubiac believes that, in sucli cases, artistic value is the determining factor. Gaubiac, supra note 48, at 56-59; cf. Reichman, After the Copyright Act, supra note 65, at 329-33, 347-50 (discussing recent Second Circuit decisions). 
ily be distinguished froin overt tests of artistic value used in the Federal Republic of Germany and, nore recently, in the Benelux countries. ${ }^{406}$

Critics like to point out that scindibiltà, even when amphified by the doctrine of conceptual separability, leads to results no less arbitrary than those obtained by adopting less "formally unexceptionable" criteria. 407 If the Italian criterion of separability were too literally apphed, purpose or destination tests would govern, despite doctrinal protestations to the contrary. ${ }^{408}$ If the criterion were apphed too liberally, by means of an expansive reading of "conceptual separability," the controlling factor would be inerit and a de facto regime of partial cumulation would ensue. 409 Between these two extremes lies a potential for metaplyysical excursion that is obviated by the judicial expedient of holding three-dimensional designs of useful articles to be inseparable as a matter of law in almost all cases. ${ }^{410}$

This judicial expedient causes "separability" to function as a channel that leads unerringly to the special regime of design protection. Under tlee Italian Design Law of 1940, if a manufacturer fails to register promptly, in the liope that a given creation may later turn out to be a separable work of applied art, lie exposes himself to the risk of prior divulgation, which destroys novelty and casts the design into the public domam. ${ }^{411}$ A restrictive doctrine of separability tlus encourages manufacturers to use the broad range of protection provided for both ornamental designs and utility models, and helps to keep imdustrial designs froin encroaching upon either patent or artistic property law.

Theoretical shortcomings of the Italian noncumulationist model inust therefore be weighed against its functional objectives. Unlike re-

406. See Reichman, After the Copyright Act, supra note 65, at 293-97, 327-40, 380-82; see also infra note 430 . Sena accepts the logical consequences of this position, namely, that the criterion of conceptual separability, as governed by a test of artistic value, would approximate a regime of partial cumulation based on a similar test of artistic value. G. SENA, supra note 205, at 453.

407. See supra note 226 .

408. See the recent example mentioned by Bennssi, supra note 48 , at 119 , and the admonitions of F. PERRET, supra note 2, at 259.

409. See most recently, Gaubiac, supra note 48, at 56-57. Algardi is less sweeping: although many designs of useful articles may be said to possess "an autonoinous aesthetic value, not all the difficulties that arise from the application of the criterion [of conceptual separability] have been overcome." Z.O. AlGardi, supra note 61, at 76 (trans.). Algardi cited only one recent case finding conceptual separability. See supra note 402. Franzosi and Benussi are more scathing. Benussi declared that "the criterion of ideal dissociability [i.e., conceptual separability], is not false but certainly illusory." F. Benussi, LA Tutela Del Disegno Industriale 145-46 (1975)(trans.); accord Franzosi, supra note 211, at 110.

410. See supra notes $220-23,402$ and accoinpanying text. The case law illustrating instances of "separable" works of applied art, as reviewed by Benussi in 1975, dates back to the 1920's and 1930's. F. BENUSSI, supra note 409, at 144-45. During this period the theory of dissociation was being formulated in reaction to a short-lived codification of the unity of art thesis. See supra notes $210,403$.

411. See supra notes 362,398 and accompanying text. 
gimes of total cumulation, the Itahan model prevents designs with low creative content from gaining copyright protection. Unlike regimes of partial cumulation, the Italian system does not subject designs seeking copyright protection as applied art to a direct test of creative value on a case-by-case basis. What enables the Italian system to operate, despite the weaknesses of the separability criterion, ${ }^{412}$ is the existence of a fully developed regime of special design protection coupled with a systemic determination to consign three-dimensional designs and models to this regime.

2. Separability American Style. Congress continued to delay passage of a sui generis design law. From 1960 on, the United States Copyright Office was therefore obliged to administer a doctrine of separability without the regime of special design protection that buttressed the Italian system. Manufacturers of ornamental designs excluded from copyright law by the separability test in Regulation Section 202.10 (c) could fall back only on the design patent law or the law of unfair competition.

Under the design patent law, the standard of nonobviousness was applied rigorously to industrial art. ${ }^{413}$ Most United States courts, especially those at the appellate level, insisted on an exceptionally large "inventive" step, sometimes acting upon a virtually conclusive presumption that combination designs were obvious as a matter of law. ${ }^{414}$ Other courts reached a similar result by allowing patented designs to be disassembled into their component parts and attacked on grounds of obviousness by piecemeal application of the prior art, usually without

412. See supra notes 404-09 and accompanying text.

413. In 1952, Congress codified the imvention requirement of 35 U.S.C. $\$ 103$ in terms of nonobviousness; section 103 applies to designs because of the provision in 35 U.S.C. $\S 171$ (1982) "that design patents are 'subject to the conditions and requirements of this title." $1 \mathrm{D}$. CHIsum, supra note 367, § 1.04[2], at 1-129. At the time of the Patent Codification Act of 1952, the design pateut law had briefly appeared more receptive. See, e.g., Glen Raven Knitting Mills v. Sanson Hosiery Mills, 189 F.2d 845, 849 (4th Cir. 1951). Soon, however, the standard of nonobviousness, which had been substituted for the "flash of genius" test of invention, was applied strictly to imdustrial art, perhaps even more strictly than to utility patents. See supra notes 140,245 and accompanying text; see also Dulin, supra note 16, at 359; Comment, Design Protection-Time to Replace the Design Patent, 51 MinN. L. REv. 942, 952-55 (1967). Yet an extremely high standard of nonobviousness for aesthetic designs is neither more nor less mandatory in the United States than under Italian law. Gorham Co. v. White, 81 U.S. (I4 Wall.) 5I 1, 524-26, 531 (1872); see I D. CHISUM, supra note $367, \S 1.04[2]$, at 1-130 ("courts openly admit that any assessment of the obviousness of the solution is necessarily subjective"); Reichman, After the Copyright Act, supra note 65 , at 311-13, 333-36 (reporting favorable trend in design patent law).

414. See, e.g., G.B. Lewis Co. v. Gould Prods., 436 F.2d I176, 1178 (2d Cir. 1971); Rains v. Niaqua, Inc., 406 F.2d 275, 279 (2d Cir.), cert. denied, 395 U.S. 909 (1969); Day-Brite Lighting, Inc. v. Sandee Mfg., 286 F.2d 596, 599 (7th Cir. 1960), cert. denied, 366 U.S. 963 (1961). But see Rains v. Cascade Indus., 402 F.2d 241, 246-47 (3d Cir. 1968). 
regard to commercial success. ${ }^{415}$ Still other courts routinely found modern functional designs wanting in ornamentality or excessively influenced by technical factors. ${ }^{416}$ Taken together, these approaches reflected a judicial hostility toward the existing design protection law ${ }^{417}$ that was very different from the flexible attitude of Italian courts toward the Italian Design Law of 1940.418

United States unfair competition law provided little protection for ornamental designs of useful articles before the 1950's. ${ }^{419}$ Although inanufacturers sought registration as inarks for certain product configurations even before the decision in Mazer v. Stein, neitler courts nor practitioners during this period seriously regarded section $43(\mathrm{a})$ of the

415. See, e.g., Hadco Prods. v. Walter Kidde \& Co., 462 F.2d 1265, 1273 (3d Cir.), cert. denied, 409 U.S. 1023 (1972); Blumcraft of Pittsburgh v. Citizens \& S. Nat'l Bank, 407 F.2d 557, 559 (4th Cir. 1969); Trimble Products v. W.T. Grant Co., 404 F.2d 344, 345 (2d Cir. 1968). But see In re Laverne, 356 F.2d 1003, 1006 (C.C.P.A. 1966)(ordimary observer standard substituted for that of ordinary designer). See generally Michaelson, Design Patents and Obviousness-Obviousncss to Whom?, 52 J. PAT. OFF. Soc'y 620 (1970); Comment, supra note 413, at 952-55.

416. See, e.g., Barofsky v. General Elec., 396 F.2d 340, 342-44 (9th Cir. 1968), cert. denied, 393 U.S. 1031 (1969); Payne Metal Enters. v. McPhee, 382 F.2d 541, 546 (9th Cir. 1967); Bentley v. Sunset House Distrib. Corp., 359 F.2d 140, $145-46$ (9th Cir. 1966); Blisscraft of Hollywood v. United Plastics Co., 294 F.2d 694, 696 (2d Cir. 1961); see also Nimetz, supra note 18, at 113-21.

417. See supra note 245 and accompanying text. These approaclies were also opposed to the fiexibility introduced by the Suprene Court in both Gorham Co. v. White, 81 U.S. (14 Wall.) 511 , 524-26, 531 (1872) and Graham v. John Deere Co., 383 U.S. 1 (1966), affg 333 F.2d 529 (8th Cir. 1964). But conrts such as the Umited States Courts of Appeals for the Second and Third Circuits resisted the implications of Deere for design patents, including the Supreme Court's willingness to consider secondary factors, and sometimes cited instead Great Atl. \& Pac. Tea Co. v. Supermarket, 340 U.S. 147 (1950). See, e.g., Hadco Prods. v. Walter Kidde \& Co., 462 F.2d 1265, 1269 (3d Cir. 1972).

For the improved situation after 1974, see Reichman, After the Copyright Act, supra note 65, at $311-13,333-36$.

418. See supra text accompanying notes 364-73.

419. See, e.g., Cheney Bros. v. Doris Silk Corp., 35 F.2d 279, 280 (2d Cir. 1929), cert. denied, 281 U.S. 728 (1930); see also Derenberg, supra note 17, at 772-73. Commercial designs could be protected against misrepresentation or "palming off," provided the design or configuration had obtained secondary meaning and nonfunctional features lad been copied. Duhin, supra note 16, at 343-46. Even so, the definition of functional features could be extremely broad. See, e.g., Pagliero v. Wallace China Co., 198 F.2d 339, 343 (9th Cir. 1952); J.C. Peimey Co. v. H.D. Lee Mercantile Co., 120 F.2d 949, 954 (8th Cir. 1941). See generally 3 R. Callmann, Unfalr ComPETITION, TRADEMarks AND Monopolies, $\$ 19.35$, at 148-53 (4th ed. Supp. 1983). As regards misappropriation, however, United States law did not officially recognize slavish imitation alone as a tort. Derenberg, supra note 17, at 772-73, 782-83; see infra note 428. Its apphication to commercial designs prior to the 1950's was largely negated by Cheney Bros. v. Doris Silk Corp. See Design Protection Hearings 1961, supra note 21, at 70 (statement and testimony of Phibip T. Dalsimer, New York Patent Law Association).

Private efforts in the United States to prevent design piracy through guild sanctions were reportedly effective, but the methods contravened the antitrust laws. Fashion Originators' Guild of America, Inc. v. FTC, 312 U.S. 457, 463 (1941); see also Millinery Creators Guild v. FTC, 109 F.2d 175, 176 (2d Cir. 1940), affd, 312 U.S. 469 (1941); Design Protection Hearings 1961, supra note 21, at 102 (statement of Nat Abelson). 
Lanham Act as capable of protecting unregistered designs. ${ }^{420}$ As state courts changed their course in the 1950's and increasingly extended common law concepts, including misappropriation, to commercial designs, ${ }^{421}$ the einerging trend deflected the attention of the practicing bar away from the deeper implications of Mazer itself. ${ }^{422}$ When, therefore, the Sears-Compco decisions of the United States Supreme Court in 1964 souglit to preempt state actions sounding in misappropriation for unpatentable designs of useful articles, ${ }^{423}$ the shock provoked a former Chairman of the American Bar Association's Committee for the Protection of Industrial Designs to exclaim, "We have come to the end of the road." 424

420. Owners of unregistered designs had sought access to $\S 23$ of the Lanham Act as regards configurations of goods, but mainly by probing the limits of sections 44(h) and (i). Derenberg, supra note 17, at 630-36; Derenberg, Federal Unfair Competition Law at the End of the First Decade of the Lanham Act: Prologue or Epilogue, 32 N.Y.U. L. REv. 1029, 1031 (1957) [hereinafter cited as Derenberg (1957)].

The Lanham Act § 43(a), 15 U.S.C. \$ 1125(a) (1982), prohibits "false designation of origin, or any false description or representation." Shapes and configurations that are capable of indicating source have been allowed to register with the Patent and Tradeinark Office since In re Minnesota Mining \& Mfg., 335 F.2d 836, 837 (C.C.P.A. 1964). Section 43(a), as currently interpreted, covers claims for infringement of unregistered marks, including designs that function as trademarks. Diamond, Current Protection of Designs of Useful Articles Under the Law of Trademarks, reprinted in 1982 ABA-SEction PATENT TRADEMARK \& COPYRIGHT LAW 204-05. In recent years, section 43(a) has also been used to deter various forms of unfair coinpetition; the scope of federal protection provided by this section is expanding. Id. at 205-06.

421. See, e.g., Dior v. Milton, 9 Misc. 2d 425, 431-35, 155 N.Y.S.2d 443, $451-55$ (Sup. Ct.) (which relied expressly on International News Serv. v. Associated Press, 248 U.S. 215 (1918)), affd, 2 A.D. 2d 878, 156 N.Y.S.2d 996 (1956); Dulin, supra note 16, at 347-48. Courts dealing with slavisl imitation in this period were increasingly disposed to create a presumption of secondary meaning in the presence of a minimum showing of a likelihood of confusion. See, e.g., Mastercrafter's Clock \& Radio v. Vacheron Le Coultre Watches, Inc., 221 F.2d 464, 467 \& n.7 (2d Cir.), cert. denied, 350 U.S. 832 (1955); cf. Vacheron \& Constantin-Le Coultre Watches Inc. v. Benrus Watch Co., 155 F. Supp. 932, 936 (S.D.N.Y. 1957)(finding that the plaintiff's design had not acquired a secondary ineaning), modified, 260 F.2d 637 (2d Cir. 1958); see also supra text accompanying notes 184-96. "While unfair competition was originally applied to the palming off of one's goods as those of a rival trader . . . this limited view has been considerably broadened in recent years, particularly in the State of New York, to include what is an unfair course of dealing, even without proof of an established secondary meaning." Flint v. Oleet Jewelry Mfg. Co., 133 F. Supp. 459, 464 (S.D.N.Y. 1955); see also Audio Fidelity, Inc. v. High Fidelity Recordings, 283 F.2d 551, 554 \& n.4 (9th Cir. 1960)(trade dress); Ideal Toy Corp. v. Adanta Novelty Corp., 223 F. Supp. 866, 869 (S.D.N.Y. 1963). Federal courts in these cases were applymg state law.

422. "Now, [Mazer v. Stein] was a revolutionary decision, but it took a while for people who had been headed off in another direction to realize what it had to offer them." Hearings 1975, supra note 169, at 1856-57 (testimony of Barbara Ringer, Register of Copyrights); see also Ringer, supra note 233, at 29-30 (doctrine of misappropriation then a disquieting "speck on the horizon").

423. Sears, Rocbuck \& Co. v. Stiffel Co., 376 U.S. 225, 231 (1964); Compco v. Day-Brite Lighting Inc., 376 U.S. 234, 238 (1964); see Diamond, supra note 420, at 212-14.

424. Dalsimer, supra note 90 , at 173 . He continued:

We have come to the end of the road. . . This is a complex area. The complexity of this area, of what is trademark, what is design, what is functional, what is nonfunctional, 
The Copyright Office thus found itself in a dehcate position. If it slackened its determination to "hold the line" against copyright protection of ornamental designs of useful articles, then vested interests Register Fisher had sought to ward off before his death might multiply. ${ }^{425}$ There would be less interest in changing the status quo and a new design protection law could become inore difficult to obtain. If its resistance, based on separability, gave rise to inconsistent results, at either the administrative or the judicial level, ${ }^{426}$ such results might provoke a "unity of art" reaction leading to broad copyright protection for industrial art.427 If designs excluded by the Copyright Office were routinely copied by slavish imitators, ${ }^{428}$ courts might attempt to use state or federal unfair competition law to grant protection of indeterminate length on the basis of standards that spokesinen for the Copyright Office had

has indicated to tne the wisdom that the law of unfair competition should be left open and developing, not foreclosed as the Supreme Court appears to have done.

Id. at 173-74. A leading scholar was equally shocked: "[T]he Sears-Compco decisions of 1964 ... wiped out a hundred years of common law unfair competition law which had prohibited the simulation of non-functional shapes which were likely to confuse buyers." $1 \mathrm{~J}$. MCCARTHY, TRADEMARKS AND UNFAIR COMPETITION \$ 7.24, at 190 (1973). Dulin, instead, immediately (and correctly) predicted the expansion of Lanham Act $\S 43($ a) if a design bill was not enacted. Dulin, supra note 16, at 358-59; see also supra note 420; Reichman, After the Copyright Act, supra note 65, at 379-80, 386 (post-1976 tendencies).

425. See supra notes 194-95, 294 and accompanying text; Kaminstein, Fisher Memorial, supra note 26 , at xiii.

426. This is the sense in whicn Professor Nimmer asks how it is possible to know when "the sole intrinsic function" of a work was to be found in its utility or when its artistic features were to be "identified separately" and "capable of existing independently" as a work of art. $1 \mathrm{M}$. NiMMER, supra note 1, § 2.08[B], at 2-89 and 2-90; $c$. Desbois, supra note 60, at 74 (quoted supra note $81)$.

427. See supra text accoinpanying notes 79-88. Energetic resistance would also expose the Copyright Office to direct attacks on its authority to act as art critic, a question also himted at in Vacheron. See, e.g., Crowley, The Register of Copyrights as an Art Critic, 11 CopYright L. SYMP. (ASCAP) 155, 161-69 (1962); Reed, The Role of the Register of Copyrights in the Registration Process: A Critical Appraisal of Certain Exclusionary Regulations, 18 COPYRIGHT L. SYMP. (ASCAP) $1,5-10,17-27,31-38$ (1970).

428. The use of a competitor's product as a pattern imight be described as copying by duplication, as opposed to copying by imitation. Duplication, like photocopying, results in a nearly exact copy. But imitation can also produce a very close copy. Both inethods of producing nearly indistinguishable copies are . . . referred to as "slavish" copying. The term "Chimese" copy, sometimes heard, is synonoinous.

1A R. CALlMAN, supra note $419, \S 4.60$, at 92 n.1. Also synonounous are the terms "slavish imitatiou" and "servile imitation," used in both domestic and foreign bterature. See, e.g., E.J. KASE, Dictionary of Industrial Property-Legal and Related Terms 53 (1980); Derenberg, supra note 17, at 773 (complains that doctrine of misappropriation, despite "hopeful beginnings," could not be used to repress slavish imitation of works of applied art after Cheney Bros. v. Doris Silk Corp., 35 F.2d 279 (2d Cir. 1929), cert. denied, 281 U.S. 728 (1930)). Derenberg observed that "the geueral law of unfair competition in most civil law countries reflects a much broader and more flexible approach toward unfair trade practices." Id. at 782; see, e.g., Ulmer, Unfair Competition Law in the European Economic Community, 4 IIC 188, 197 (1973)("Slavish imitation . . . presents problems that are familiar and particularly difficult to solve."); see also supra notes 41924 and accompanying text. 
earlier termed "virtually nonexistent."429 An hypothesis suggested by foreign law is that the longer Congress delayed in passing the design bills, the more the United States faced a choice between overprotection in copyright law, on the French and Belgian nodels, or overprotection in unfair competition law as had occurred in the Netherlands, which, prior to 1975, had also tried to exclude nıost designs fronı copyright law without the safety net of a special design law.430

An often-cited article published by law students at the University of Chicago in 1971 provides a framework for examining this hypothesis. 431 The authors asserted that Mazer $v$. Stein had opened a "brave new world of copyright law" by extending the scope of protection beyond "the normal concepts of works of fine art" and by indiscriminately admittmg mass-produced two- and three-dimensional objects, includimg many that belonged in the public doniain. ${ }^{432}$ The Chicago Critics claimed that cases dealing with appled art during the 1960's had undermined settled principles of copyright law. For example, the requirement of originahity had been so vitiated that it failed to exclude public-domain matter seeking protection as apphed art. ${ }^{433}$ The ideaexpression dichotomy had also failed to exclude commonplace designs from copyright protection. ${ }^{434}$ Courts had virtually ignored even the notice requirement. ${ }^{435}$ These failings were exacerbated by judicial application of the law of infringement, especially the "overall impression" test, which the Chicago Critics said discouraged "close exammation to detect disparities" and inade expert testimony suspect. ${ }^{436}$

429. See supra notes 242, 424 and accompanying text; Jackson, Unfair Competition by Product Simulation v. Copyright Protection for Designs, 45 J. PAT. OFF. Soc'Y 422, 424 (1963).

430. In the Netherlands, courts anxious to avoid the breadth of protection under the unity of art doctrine as implemented in Belgium elevated the requirement of creativity for copyright protection of applied art to a height inferior only to the standards in the Federal Republic of Germany. But the Federal Republic possessed a design law, wliereas the Netherlands did not. Broad exclusion of aesthetic designs from copyright law by Netherlands courts then led to broad protection of designs of useful articles in the law of unfair competition, and this in turn put pressure on the legislature to enact a design law. See Reichman, After the Copyright Act, supra note 65, at 28397.

431. Chicago Critics, supra note 142, at 807 . For important cases citing this article, see infra note 500 .

432. Chicago Critics, supra note 142 , at $807 \&$ n.7, 822.

433. Id at 812 .

434. Id. at 812, 814-16; see also Note, supra note 28, at 1532.

435. Chicago Critics, supra note 142, at 808.

436. Id. at 813. An earlier, more balanced study liad observed that the "absence of substantial variation among objects of a given functional cluaracter maximizes the difficulty of determining the fact of infringement." Note, supra note 28, at 1532 . The "overall impression" test was actually the result of a judicial attempt to narrow the breadth of protection that ensued from the practice of counting dissimilarities at the infringement stage. See infra notes 478-81 and accompanying text. 
The Chicago Critics concluded that "eliminating appropriation or commercial piracy has becoine an end in itself," and that copyright law risked degenerating into a version of the common law of unfair coinpetition, contrary to the preemptive spirit of Sears-Compco. ${ }^{437}$ In effect, this ainounted to a claim that the United States, during the 1960's, had been according as inuch protection to designs of useful articles under copyright law as countries embracing the unity of art theory. ${ }^{438}$ It would also inean that separability had failed as an exclusionary criterion, and that the entire anticunulationist fortress erected by Arthur Fisher in the late 1950's had collapsed. These critics even challenged the wisdom of the Supreine Court's decision to allow applied art to be protected by copyright law in the first instance. 439

There are a number of preliminary problems with these assertions. ${ }^{440}$ The authors' disavowal of Mazer v. Stein ignored the long and successful cainpaign within the Berne Union to break down those "norinal concepts of works of fine art" from which the Supreme Court strayed in 1954.441 How, after 1948, Register Fisher could have bridged the gap between the Berne Union countries and the Geneva Convention countries without official United States recognition of the category of apphed art is not readily understood.442 Nor did reeognition of applied art inherently lead to broad copyright protection for mass-produeed commercial products, as the Chicago Critics seemed to believe. ${ }^{443}$ On the contrary, courts in most other countries whose offi-

437. Chicago Critics, supra note 142 , at 818 .

438. See supra notes 65-66 and accompanying text (positions of France and pre-1975 Belgium).

439. Chicago Critics, supra note 142, at 807 n.7, 822 ("the logic of the situation demands . . . a complete reevaluatiou of the Mazer decision itself').

440. At first glance, the Chicago Critics' conclusions tally with predictions that seem logical on the basis of experience under foreign law. See supra text accompanying note 430. But see infra notes $482-99$ and accompanying text.

441. Chicago Critics, supra note 142, at 807 n.7; see supra notes $136-38$ and accoinpanymg text.

442. See supra notes 22-34, 138 and accompanying text. Had Fisher's design bill, S. 2075, supra note 158, not been supplanted by S. 1884, see Design Protection Hearings 1961, supra note 21, the Copyright Office might eventually have faced this same question at the international level. The answer might have suggested that S. 2075 conferred a form of copyright protection and that even the Berne Convention expressly permitted its meinbers to limit the duration of protection accorded applied art in doinestic copyright laws. See supra note 279 and accompanying text. Here, as elsewhere, retention of the design patent law aloug with the sui generis design law served varied and subtle ends.

443. Chicago Critics, supra note 142, at 807 (title). Once it had recognized applied art in $M a$. zer v. Stein, the Umited States lad either to protect all aesthetic designs im copyright law or adopt some exclusionary criterion of its own. The Chicago Critics conceded that the distinction between "mass-produced products" and "uormal concepts of works of fine art" was "not self-defining," particularly because inany mass-produced works of so-called fine art having little or no artistic value, such as decorative paintings, had also to be accounted for. $1 d$. at 807 n.7. But tliese critics offer no criterion of their own for singling out works falling within the "normal concept" of art 
cial positions concerning applied art differed widely had all found neans of absorbing their domestic analogues of Mazer $v$. Stein without succumbing to the unity of art temptation. ${ }^{444}$

Even if the United States had entered a unity of art phase during the 1960's, as may be inferred from the Chicago Critics' article, allowance must still be made for the scope of protection afforded by the Copyright Act of 1909 as compared with that of the Berne Convention of 1948. The copyright paradignu underlying Mazer v. Stein, with its formalities of pubhication with notice, registration, and deposit, its relatively short duration, and its lack of moral rights, seenus closer in spirit to the special design laws enacted abroad than to the copyright paradign of the Berne Union. ${ }^{445}$ Copyright protection on American teruns, even if routinely granted, was arguably not excessive by world standards, especially after the Paris Industrial Union, to which the United States belongs, had itself mandated the protection of industrial designs. ${ }^{446}$ Given an invalidation rate of one hundred percent for design patents at the appellate level,447 upholding copyrights in "applied art" provided the only consistent evidence that the United States was meeting its obligations under the Paris Convention during this period.

This appraisal thus suggests that the most drastic conclusions of the Chicago Critics did not necessarily follow from their findings; moreover, the validity of these findings is itself questionable. Decisions vahdating the copyrights of most subject matter reviewed during the period 1959-1969 were not radical departures fron precedent, except for those concerning fabric designs, which immediately benefited fron the Copyright Office's need to reconcile separability witl Mazer $v$. Stein. 448 The chimpanzee doll, upheld even before the 1956 version of

that would not contradict Bleistein; and they do not disassociate themselves from the discredited views of an earlier age that "art" and "utility" were intrinsically antithetical.

444. See supra note 200 (Italy); supra note 430 (Netherlands); Reichman, After the Copyright Act, supra note 65, at 283-97 (Benelux group), 333-40 (Federal Republic of Germany). Italy did in fact succumb to the unity of art doctrine for a brief period, but courts and commentators quickly reversed the situation. See supra notes 210,410 .

445. See supra note 166 and accompanying text.

446. See supra text accompanying notes 111-12.

447. See supra note 413.

448. See, e.g., Peter Pan Fabrics, Inc. v. Martin Wemer Corp., 274 F.2d 487, 489 (2d Cir. 1960); Peter Pan Fabrics, Inc. v. Candy Frocks, Inc., 187 F. Supp. 334, 335 (S.D.N.Y. 1960); Scarves by Vera, Inc. v. Umited Merchants, 173 F. Supp. 625, 627 (S.D.N.Y. 1959); Peter Pan Fabrics, Inc. v. Brenda Fabrics, Inc., 169 F. Supp. 142, 143 (S.D.N.Y. 1959). Professor Latman considered that the status of fabric designs in this period had improved dramatically. Latman, supra note 9, at 281. A Swiss observer agreed. See H. SeCretan, supra note 45, at 128-29.

Separability as such was not treated im these decisions, which seem to have followed the lead of the Copyright Office in regarding fabric designs as two-dimensional paintings applied to textiles. See Regulation § 202.10(b) (1959), supra note 199. The Copyright Office, in turn, was self- 
the regulation, ${ }^{449}$ was followed by other dolls, ${ }^{450}$ by plastic banks shaped to resemble pet dogs, ${ }^{451}$ and by a hobby horse. ${ }^{452}$ Similarly, the cases that routinely found designs of costume jewelry copyrightable between 1955 and $1958^{453}$ were followed by decisions upholding designs of "garish trinkets," 454 and of an ornainental jewelry box. ${ }^{455}$

These cases were significant both for the number of items allowed into copyright law and for the minimal artistic values tolerated;456 but

consciously implementing Mazer $v$. Stein, which, aftcr the Vacheron decision in 1958, could not be emptied of meaning. See supra text accompanying notcs 184-96, 224-25. Another two-dimensional design admitted in this period concerncd a pattern for dinnerware. Syracuse China Corp. v. Stanley Roberts, Inc., 180 F. Supp. 527 (S.D.N.Y. 1960).

The main issues that fabric designs raised in this period concerned origimaity, e.g., Peter Pan Fabrics, Inc. v. Acadia Corp., 173 F. Supp. 292, 299-300 (S.D.N.Y. 1959), and notice (a copyright notice could be cut off the selvage of a fabric and elicit a claim of publication without notice), e.g.s Peter Pan Fabrics, Inc. v. Martin Wiener Corp., 274 F.2d at 488-90. These issues were now usually resolved in favor of plaintiffs. See, e.g., Latman, supra note 9, at 283. But see, e.g., H.M. Kolbe Co. v. Armgus Textile Co., 279 F.2d 555, 556-57 (2d Cir. 1960)(requiring notice to be repeated on wide designs).

449. Rushton v. Vitale, 218 F.2d 434, 435 (2d Cir. 1955); see supra text accompanying note 159.

450. See, e.g., Ideal Toy Corp. v. Sayco Doll Corp., 302 F.2d 623, 624 (2d Cir. 1962)(but see dissent of Judge Clark); Mattel, Inc. v. S. Rosenberg Co., 296 F. Supp. 1024, 1025 (S.D.N.Y. 1968). Some of the dolls upheld looked like popular musicians or coinbat soldiers. See, e.g., Hasscnfeld Bros. v. Mego Corp., 150 U.S.P.Q. (BNA) 786, $788-89$ (S.D.N.Y. 1966); Remco Indus., Inc. v. Goldberger Doll Mfg. Co., 141 U.S.P.Q. (BNA) 898, 899 (E.D.N.Y. 1964).

451. Royalty Designs, Inc. v. Thrifticheck Serv. Corp., 204 F. Supp. 702, 704 (S.D.N.Y. 1962)(copyright on plastic bank in shape of dog valid). But see L. Batlin \& Son v. Snyder, 536 F.2d 486, 492 (2d Cir.)(en banc)(copyright on plastic copy of antique "Uncle Sam" bank invalid for lack of "substantial originality"), cert. denied, 429 U.S. 857 (1976).

452. Blazon, Inc. v. Deluxe Game Corp., 268 F. Supp. 416, 421 (S.D.N.Y. 1965)(design of model horse is copyrightable). But see Uneeda Doll Co. v. P. \& M. Doll Co., 241 F. Supp. 675, 677 (S.D.N.Y.) (abstract idea not copyrightable), affd, 353 F.2d 788 (2d Cir. 1965)(per curiam)(in which misgivings were expressed). The copyrightability of scale-model airplanes was upheld in 1971. See Monograin Models, Inc. v. Industro Motive Corp., 448 F.2d 284, 285 (6tl Cir. 1971), aff' on appeal after remand, 492 F.2d 1281, 1284 (6th Cir.), cert. denied, 419 U.S. 843 (1974).

453. See supra notes $158,184-96$ and accompanying text.

454. Dan Kasoff, Inc. v. Novelty Jewelry Co., 309 F.2d 745, 746 (2d Cir. 1962). Also upheld were the designs of a jewel-encrusted turtle pin, Herbert Rosenthal Jewelry Corp. v. Grossbardt, 428 F.2d 551, 553 (2d Cir. 1970), and of a jewelled pim in the shape of a bee, Herbert Roscnthal Jewelry Corp. v. Grossbardt, 436 F.2d 315, 316 (2d Cir. 1970). But see Herbert Rosenthal Jewelry Corp. v. Kalpakian, 446 F.2d 738, 742 (9th Cir. 1971)(jewelled bee pim mere idea not protectible in copyright).

455. Dan Kasoff, Inc. v. Gresco Jewelry Co., 204 F. Supp. 694, 695 (S.D.N.Y. 1962), affd, 308 F.2d 806 (2d Cir. 1962)(per curiain).

456. "The courts have becn forced to grapple here, more than in other contexts, with the consequences of immaterial variations in the works in question." Latman, supra note 9, at 282 (citing Scarves by Vera, Inc. v. United Merchants, 173 F. Supp. 625 (S.D.N.Y. 1959)).

Secretan was similarly struck by the minimal levels of creativity tolerated by United States courts in this period; like Arthur Fisher in 1960, he predicted an expansive phase, given the prevailing standard of originality. H. SECRETAN, supra note 45, at 128-31. But see Gardenia Flowers, Inc. v. Joseph Markovits, Inc., 280 F. Supp. 776, 781-82 (S.D.N.Y. 1968); Florabelle Flowers, 
they dealt mainly with borderline subject matter protected by United States copyright law before the copyright authorities had fashioned any official response to Mazer v. Stein. When Bailie v. Fisher overtly raised the banner of "art in the historical sense" in 1958, the status of toys, dolls, and jewelry may indeed have been threatened. 457 These itenis might have been definitively denied copyright protection if Congress had enacted S. 2075, which attenpted to insulate copyright law from ornamental designs embodied in useful articles. ${ }^{458}$ After the "antimaim" compromises of the period 1961-1964, however, the Copyright Office could not maintain that the "sole intrinsic function" of toys, dolls, and jewelry was their utility when the utilitarian character of such objects remained uncertain under either the general revision bill or the pending design bills. ${ }^{459}$ Most of the three-dimensional designs dealt with in these cases seemed closer to the traditional, figurative statue in Mazer v. Stein than to the modern, functional designs that were of paramount concern to the copyright authorities. Even if borderline designs of toys, dolls, and jewelry were henceforth to be viewed as designs of "useful articles" subject to the test of separability, nnost of them should have passed the test. ${ }^{460}$ The opmions rarely niention techmical issues of separability and utilitarian function, an omission consis-

Inc. v. Joseph Markovits, Inc., 296 F. Supp. 304, 305 n.2 (S.D.N.Y. 1968) (invalidating copyrights in designs of artificial flowers for insufficient creativity and originality); Reichman, After the Copyright Act, supra note 65, at 271-76 (discussing these cases), 276-83 (discussing Hubinann's theory of the creative work).

457. 258 F.2d 425, 426 (D.C. Cir. 1958)(per curiain); see supra notes 189-9l and accompanying text.

458. See supra notes $255-71$ and accompanying text.

459. See supra notes $295-302,313,330-44$ and accompanying text. The criterion of separability adopted by the Copyright Office in 1958 was quickly interpreted as follows: "Excluded froin copyright registration as a 'work of art' . . . is an article whose 'sole intrinsic function is its utility,' even if it is 'unique and attractively shaped.' "Present Design Protection, supra note 48, at 139. On its face, this language simply restates one of the basic tenets of Baker v. Selden, 101 U.S. 99, 102 (1880), that prevents manufacturers from using copyright law to circumvent the patent law. The author of the Note on Present Design Protection, in seeking to explaim that the test of separabilty excludes purely functional designs of useful articles, seems to have conveyed the impression that the "sole intrinsic function" language also constituted the definition of useful articles thereafter to be applied by the Copyright Office; this, indeed, is the conventional assumption of the hiterature. If true, few ornamental designs would necessarily have been subject to the test of separability. The Copyright Office's preferred definition of useful articles (cast in terms of "an intrinsic utilitarian function") had been pending since the 1959 design bill, however, and was maintained in all the general revision bills. In the meantime, the evidence suggests that the Copyright Office was actually employing its own practical definition or rules of thumb that were not widcly perceived by the profession. See Compendium of Copyright Office Practices 2-274 (1973); supra note 341; infra notes 513-16 and accompanying text.

460. See Register's REPORT 1961, supra note 45, at 12-13. 
tent with the interest of the Copyright Office in not arousing opposition to the design bills from quarters already pacified.461

The Chicago Critics' claim that the period 1959-1969 was characterized by an uncontrolled expansionist trend thus rests on the admission of artificial flowers beginning in 1962;462 of a stand-up, stuffable Santa Claus decoration that saine year; 463 and of a pencil sharpener disguised as an antique telephone in 1966.464 But these decisions can be rationalized in terms of inaterial separability, which, in the absence of a special design law, necessarily tolerates a buffer zone of protectibility for designs with an affinity to the statuettes upheld in Mazer v. Stein. ${ }^{465}$ The Santa Claus decision was the inost dubious, not because of a deviation from the doctrime of separability, but because the court may have erred in protecting the stand-up mechanism, a utility nodel in disguise. 466

The pencil sharpener case-Ted Arnold Ltd. v. Silvercraft Co. ${ }^{467}$ reinforced the defense of the copyright fortress in this period. Although the district court in Ted Arnold upheld the copyright in the design, it squarely acknowledged the need for ornamental designs of useful articles to satisfy the test of separability at a time when most cases, dealing with traditional borderline categories, ignored this issue. ${ }^{468}$ The court demonstrated the exclusionary power of the doctrine by applying it retroactively to the modernistic watch-face design denied

461. REGISTER's DRAFT REPORT 1975, supra note 36, ch. V11, at 22; Hearings 1975, supra note 169, at 993 (testimony of Alan Latman).

462. See Prestige Floral, S.A. v. California Artificial Flower Co., 201 F. Supp. 287, 291 (S.D.N.Y. 1962); see also Fristot v. First Am. Natural Ferns Co., 251 F. Supp. 886, 887-88 (S.D.N.Y. 1966). But see Florabelle Flowers, Inc. v. Joseph Markovits, Inc., 296 F. Supp. 304, 305 n.1 (S.D.N.Y. 1968)(commonplace design not copyrightable); Gardenia Flowers, Inc. v. Joseph Markovits, Inc., 280 F. Supp. 771, 781-82 (S.D.N.Y. 1968)(commonplace design not copyrightable); Rico, Ltd. v. Hub Floral Mfg. Co., 206 F. Supp. 192, 195 (S.D.N.Y. 1962)(not infringed); Prestige Floral, S.A. v. Zunino-Altman, Inc., 203 F. Supp. 649, 653 (S.D.N.Y. 1962)(not mfringed), affd, 301 F.2d 286 (2d Cir. 1962)(per curiam).

463. Doran v. Sunset House Distrib. Corp., 197 F. Supp. 940, 944 (S.D. Cal. 1961), affd, 304 F.2d $25 I$ (9th Cir. I962).

464. Ted Arnold Ltd. v. Silvercraft Co., 259 F. Supp. 733, 736 (S.D.N.Y. 1966).

465. Material separability was expressly discussed in the case of the pencil sharpener disguised as an antique telephone. Ted Arnold Ltd. v. Silvercraft Co., 259 F. Supp. 733, 736 (S.D.N.Y. 1966). Professor Perret cites this United States decision as illustrating the "universal appeal" of the theory of dissociation. F. PERRET, supra note 2, at 264 n.258; see supra notes 402, 409-10.

The acceptance of artificial fiowers was derived by analogy from the two-dimensional floral pattern of the fabric design upheld in Peter Pan Fabrics, Inc. v. Candy Frocks, Inc., 187 F. Supp. 334, 336 (S.D.N.Y. 1960). See Prestige Floral, S.A. v. California Artifical Flowcrs Co., 201 F. Supp. 287, 290-91 (S.D.N.Y. 1962). But this result was challenged on other grounds in 1968. See authorities cited supra note 456.

466. See $1 \mathrm{M}$. NimMER, supra note $1, \S 2.08[\mathrm{~B}]$, at 2-89 n.97.1, 2-90 n.100.1.

467. 259 F. Supp. 733 (S.D.N.Y. 1966).

468. Ted Arnold, 259 F. Supp. at 734-35. 
registration under the first post-Mazer regulation of 1956.469 The earlier result was ratified, in dicta, on the ground that the design of the watch face, although capable of being identified separately, was incapable of independent existence "apart from the rest of the watcl.."470

The Ted Arnold court's insistence on rationalizing the Vacheron decision in terms of the posterior criterion of separability was but one indication of subtle judicial resistance to applied art that even traditional borderline categories continued to encounter throughout the 1960 's. In 1962, for example, Judge Clark of the Second Circuit attacked the practice of sustaining "a monopoly of unique and disturbing character" in a case upholding the copyrightability of a doll: "what the plaintiff could not get under the patent law (as it in effect concedes by its course of conduct) it has succeeded in getting in three-to-five fold neasure under the copyright law." 471 Plaimtiff's "most natural appeal would be for a design patent," but as Judge Clark observed, "it is well known that manufacturers have been disappointed in this law, since almost no design patents have stood up in tlie courts, facing as they do the twin barriers of a showing of a novel design and of infringement." 472 He deplored the shift to copyright law after Mazer $v$. Stein ${ }^{473}$ whicll made a fifty-six year monopoly available in an appropriate case. 474

Other courts in this mood resorted to standard technical devices in order to limit the scope of protection afforded those subject-matter cat-

469. See Vacheron \& Constantin-Le Coultre Watches v. Benrus Watch Co., 155 F. Supp. 932 (S.D.N.Y. 1957), modified, 260 F.2d 637 (2d Cir. 1958); see supra notes 184-91 and accompanying text.

470. Ted Arnold, 259 F. Supp. at 734-35.

471. Ideal Toy Corp. v. Sayco Doll Corp., 302 F.2d 623, 625-26 (2d Cir. 1962)(Clark, J., dissenting).

472. Id. at 626. Judge Clark exaggerated the difficulties of both. The real obstacle was nonobviousness or "qualitative originality." See supra notes 413-18 and accompanying text.

473. Ideal Toy, 302 F.2d at 626 (Clark, J. dissenting). It did not occur to Judge Clark that his own hostility to the design patent, apparently shared by the Second Circuit as a whole, was in part to blame for the "shift to copyright law." See supra note 178; see also supra notes 413-18 and accompanying text; Reichman, After the Copyright Act, supra note 65, at 303-08 (discussing district court cases hospitable to a patent approach).

474. Ideal Toy, 302 F.2d at 625-26 (Clark J., dissenting); see Note, supra note 28, at 1523-24, 1526. Unlike patent law, lowever, copyright law confers protection only against copying or illicit appropriation of an author's expression, as distinct from his ideas, and protcction is not forthcoining where a second work was deinonstrably created by independent effort. Suggesting that a copyright is a "inonopoly" is both misleading and harmful. Jackson, supra note 429, at 425-26; Umbreit, supra note 14, at 932 . Copyrights can be used by monopolies and oligopolies to further their market power, but this is a different question from the incentive to create and disseminate for which copyright protection is the reward. Mazer v. Stein, 347 U.S. 201, 219 (1954). 
egories recognized as copyrightable under Mazer $v$. Stein. ${ }^{475}$ Courts frequently invoked the idea-expression dichotomy for this purpose, sometimes in a heavy-handed manner. ${ }^{476}$ Tests for infringement could be restrictively apphed even to fabric designs, which were generally in favor during this period. For example, identification of public domain elements in a plaintiff's design might exonerate a defendant who had not independently resorted to the public domain matter ${ }^{477}$ More often, courts simply declined to see the requisite amount of "substantial similarity" in the allegedly infringing designs, at times by a process of counting dissimilarities. 478 But the practice of counting dissimilarities at the infringement stage in design cases could backfire when a common style trend made the corresponding count of similarities almost

475. For a time, some courts continued to speculate that three-dimensional designs and models might not be "writings of an author" in the constitutional sense, an issue raised prior to Mazer v. Stein. This resistance may have reflected "perhaps subconsciously . . . the earher hostility of courts towards protection for useful articles." Latınan, supra note 9, at 279. The issue of "writings" was pronounced dead in Monogram Models, Inc. v. Industro Motive Corp., 448 F.2d 284, 287-88 (6th Cir. 1971), aff'd on appeal after remand, 492 F.2d 1281 (6th Cir.), cert. denied, 419 U.S. 843 (1974). The phrase was removed from the copyright act in the General Revision of 1976. 17 U.S.C. $\$ \S 101,102$ (a) (1982)(works of authorship).

476. See, e.g, Millworth Converting Corp. v. Slifka, 276 F.2d 443, 445 (2d Cir. 1960)(fabrics); Uneeda Doll Co. v. P. \& M. Doll Co., 241 F. Supp. 675, 677 (S.D.N.Y.)(doll on a pole im a display box), $a f f d, 353$ F.2d 788 (2d Cir. I965); Ideal Toy Corp. v. Adanta Novelties Corp., 223 F. Supp. 866, 868 (S.D.N.Y. 1963); Condotti Inc. v. Slifka, 223 F. Supp. 412, 414-15 (S.D.N.Y. 1963)(fabrics); Clarion Textile Corp. v. Slifka, 139 U.S.P.Q. (BNA) 340, 341 (S.D.N.Y. 1961) (fabrics); Elekes v. Bradford Novelty Co., 183 F. Supp. 730, 732-33 (D. Mass. 1960). But see, e.g., Concord Fabrics, Inc. v. Marcus Bros. Textile Corp., 296 F. Supp. 736, 738 (S.D.N.Y.), rev'd, 409 F.2d 1315 (2d Cir. 1969). See also Herbert Rosenthal Jewelry Corp. v. Kalpakian, 446 F.2d 738, $741-42$ (9th Cir. 1971)(commercially successful jewelled bee pin considered merely the idea of a bee wedded to a modicum of expression). This court may have thought the design commonplace, in which case it was in part grappling with the problem of the degree of creative content. See Reichman, After the Copyright Act, supra note 65, at 271-350 (evoluton of the doctrine of substantial creativity).

The idea-expression doctrine "has been put to its most severe test in the area of design." Latunan, supra note 9, at 284.

477. See, e.g., Millworth Converting Corp. v. Shika, 276 F.2d 443, 445 (2d Cir. 1960). "Since the design was in the public domam . . . the court apphed a stricter test of imfringenent." Chicago Critics, supra note 142, at 817; see also Mattel, Inc. v. S. Rosenberg Co., 296 F. Supp. 1024, 1026-27 (S.D.N.Y. 1968)("Kiddle Kolognes" dolls, a "well-plowed field"); Manes Fabrics Co. v. The Acadia Co., 139 U.S.P.Q. (BNA) 339, 339-40 (S.D.N.Y. 1960). This defense, if carried too far, begs the question of why the commercially successful variation from a known style trend was worth stealing in the first place.

The real issue is not the presence of a public domain element in both designs nor even the magnitude of this element. The first question is always whether the defendant copicd from the public domaim or from the plaintiffs own design. A second question, typically raised in foreign cases dealing with apphed art, concerns the distance that must separate the plaintifl's soi-disant original design from the public domain version in order to retain or sustam its protectibility. See generally Reichman, After the Copyright Act, supra note 65.

478. See, e.g., Ideal Toy Corp. v. Fab-Lu Ltd., 360 F.2d 1021, 1022-23 (2d Cir. 1966); Rico Ltd. v. Hub Floral Mfg. Co., 206 F. Supp. 192, 195 (S.D.N.Y. 1962)(artificial flowers). 
certain to prevail. ${ }^{479}$ This practice was so favorable to plaintiffs that Judge Clark soon insisted that courts should adopt an overall impression test instead.480 Although the suggestion was favorably received, a finding of substantial similarity was readily forthcoming even on this test. 481

What the Chicago Critics really saw in the cases under review was in fact a tendency for slavish imitation at the infringeinent stage, ${ }^{482}$ coinbined with modest requirements of creativity and originality at the subject inatter stage, to confer a high degree of protection on those subject inatter categories that had already achieved recognition as apphed art. ${ }^{483}$ This is consistent with the nature of design imlovation, which normally develops through sinall variations on preexisting style trends.484 Within the stream of new designs launched onto the inarket each year, the cominercial success of any single variation is virtually impossible to predict in advance; the costs of design developinent must be recouped froin the few that do succeed. 485 Time pressure in market-

479. Note, supra note 28, at 1532; Chicago Critics, supra note 142 , at 817 . In principle, counting dissimilarities runs contrary to established copyright norms. 3 M. NIMMER, supra note 1, $\S$ 13.03[B], at 13-36. But sce Warner Bros. v. ABC, Copyright L. REP. (CCH) I 25,584 (2d Cir. Oct. 6, 1983)(emphasis on dissimilarity in copyright infringement actions).

480. See, e.g., Ideal Toy Corp. v. Sayco Doll Corp., 302 F.2d 623, 627 (2d Cir. 1963). In Ideal Toy, Judge Clark, in dissent, said that "reproduction should be apparent on inspection and not be based upon a counting of similarities which do not institute or leave a total impression of copying." Id. at 627; see also Mattel, Inc. v. S. Rosenberg Co., 296 F. Supp. 1024, 1026-27 (S.D.N.Y. 1968) (the Jewelry Kiddle dolls).

481. See, e.g., Roth Greeting Cards v. United Card Co., 429 F.2d 1106, 1110 (9th Cir. 1970); Concord Fabrics, Inc. v. Marcus Bros. Textiles, 409 F.2d 1315, 1316 (2d Cir. I969); Peter Pan Fabrics, Inc. v. Dan River Mills, Inc., 295 F. Supp. 1366, 1368-69 (S.D.N.Y. 1969); Fristot v. First Am. Natural Ferns Co., 251 F. Supp. 886, 887-88 (S.D.N.Y. 1966)(artificial flowers); Key West Hand Print Fabrics, Inc. v. Serbin, Inc., 244 F. Supp. 287, 292 (S.D. Fla. 1965).

482. See supra note 428.

483. "The origmality requirement is extremely minimal. Most courts ask only that the 'artist' contribute something more than trivial to his work. Frequently, all that is required of the copyrighted work is that it not be an exact duplicate of another article." Chicago Critics, supra note 142 , at 812 . Overt resistance to this doctrine developed in 1968. See authorities cited supra note 456.

484. A "characteristic distinguishing many, if not most . . . [objects of utility] from the conventional subjects of copyright, and presenting a severe challenge to any scheme of protection for designs, is the limited range of variation possible im objects of a given functional type." Note, supra note 28, at 1532; accord Latman, supra note 9, at 282-83; see supra text accompanying note 369; see also Crouwel, A Designer's View of Plagiarism, AMSTERDAM SyMPosium, supra note 21, at 161-62.

If undercurrents of judicial resistance to applied art proved less effective than Judge Clark desired, see supra text accompanying notes $471-74$, it was largely because ornamental designs slipped too easily through the nets usually employed to restrict the scope of copyright protection im simgle cases.

485. See, e.g., Hearings 1975, supra note 169, at 1005 (statement of Latman); id. at 166-67 (testimony of Tegymeyer); Design Protection Hearings 1961, supra note 21, at 52-53 (statement of Pile); id. at 105-06 (statement of Blitzer); Dulin, supra note 16, at 322; Nimetz, supra note 18, at 
ing short-hived products appealing to fancy or taste invites slavish imitators who avoid the costs of preparing their own designs and who can undersell the original designer while obliterating his indispensible lead time. ${ }^{486} \mathrm{~A}$ judicial response that protects the miniscule variation thus appropriated need not necessarily result in protection of the preexisting style trend or other public domain inatter. ${ }^{487}$ By protecting even a thin stratum of origmal matter added to that in the public domain, courts shift the burden of estabhishing independent creation to the inanufacturer who has slavishly imitated. ${ }^{488}$

To ask whether copyright law is an appropriate form of protection for aesthetic designs ${ }^{489}$ is not the same as asking whether copyright law has functioned properly with regard to designs admitted to copyrightability. The Chicago Critics complained that the "obvious course of conduct for potential copyists . . . is not to be lazy." 490 Yet this was precisely the point that inuch of the case law had been trying to make. Obligimg coinpetitors to develop even miniscule design varia-

108-09, 130-31; THE DESIGNER, No. 185 (April 1975)(issue dedicated to the "knock off"); National Committee for Effective Design Legislation, Protection for Designs, February, 1959 (unpublished); accord Duchemin, supra note 71, at 184-85; Franel \& Gaubiac, supra note 123, at 11-12, 24-25.

486. Nimetz justifies a "copyright approach" to design protection on these grounds. Nimetz, supra note 18, at 130-31. See also van der Put \& Komarnicki, Cooperation Between the Industrial Designer and the Lawyer Within an Enterprise, AMSTERDAM SYMPOSIUM, supra note 21, at 194 ("The market in Western Europe and other countries is inundated with [plagiarized] designs costing half the price of the Phillips' models, . . . [yet] the reason for the low price is . . . that the development costs are for Phillips. This is . . . a bad form of 'development aid." ").

487. See generally Reichman, After the Copyright ACt, supra note 65, at 297-350 (partial cumulation in the Second Circuit).

488. See, e.g., Kepner-Tregoe, Inc. v. Carabio, 203 U.S.P.Q. (BNA) 124, 130-31 (E.D. Mich. 1979)(thin copyrights). During the period under review, most courts were equal to the task of differentiating expression from ideas, even within the range of miniscule variations characteristic of comınercial design. Latman, supra note 9, at 282-83; see, e.g., Ideal Toy Corp. v. Adanta Novelties Corp., 223 F. Supp. 866, 868-69 (S.D.N.Y. 1963)(dolls). Nevertheless, the propensity of imfringers to imitate slavishly or to make "lazy copies" mclined these same courts, given copyrightable subject matter, to find that the defendants must necessarily have taken any quantum of protectible expression, however thin, along with the unprotectible ideas. For extreme cases in which any quantuin of protectible expression is hard to imagine, see Remco Indus. v. Goldberg Doll Mfg. Co., 141 U.S.P.Q. (BNA) 898, 899 (E.D.N.Y. 1964)(Beatle dolls) and Hassenfeld Bros. v. Mego Corp., 150 U.S.P.Q. (BNA) 786, 786-88 (S.D.N.Y. 1966)(GI Joe Dolls)(criticized by Chicago Critics, supra note 142, at 814). See also Peter Pan Fabrics, Inc. v. Dan River Mills, Inc., 295 F. Supp. 1366, 1367-68 (S.D.N.Y. 1969).

Because only original matter is protected at the infringement stage, the troublesome question in copyright law in dealing with ornamental designs is whether there was any original matter to be protected or whether there was sufficient original matter from the policy perspective. See Reichman, Affer the Copyright Act, supra note 65, at 365-86 ("Limits of the Copyright Approach").

489. Chicago Critics, supra note 142, at 824-25.

490. Id. at 816 . 
tions on a successful style trend on their own time and at their own expense is a basic principle of design protection law in all systems that provide it. What the Chicago Critics described as a degeneration of copyright law into unfair competition law was often judicial insistence that followers seeking access to the same crowded market segment should be fair. ${ }^{491}$

A tendency to protect small variations in designs falling within recognized categories of applied art, although not without drawbacks, can hardly be equated with the protection of new subject inatter categories under the expansionist trend reported by the Chicago Critics. This trend, at least with reference to the period 1959-1969, cannot be independently verified. On the contrary, the period seems remarkable for the relative impregnability of the copyright fortress to the assault of "applied art," especially im view of the defenders' lack of nodern legal weapons. Adhering as best it could to the Italian theory of dissociation, but without a special design law or some functional equivalent, the Copyright Office admitted few major new categories of subject matter that had not previously been recognized as copyrightable, at least by implication. ${ }^{492}$ Before 1970 , virtually every design held copyrightable could have withstood a test of material separability without recourse to the more abstract and expansive doctrine of conceptual separability. ${ }^{493}$ Moreover, the overall results, coherent within a framework that was concededly hard to administer, reveal a surprising absence of those ar-

491. Design Protection Hearings 1961, supra note 21, at 77 (testimony of P.T. Dalsimer); id. at 159-60 (testimony of G.D. Cary).

In this context, the term "fair followers" is used to describe a design that is "the same in general style and idea as a protected design, but which differs in detail to such a degree that it cannot be said that it reproduces the design to a substantial extent. In other words, fair followers copy, indeed they represent, the trend." D. Johnston, DESIGN Protection: A GUIDE TO THE LAW ON PlagiarisM For MANUfacturers and Designers 30 (1978)(cmphasis added). In general, fair followers (who create their own variations) are both legitimate and welcome in the field of industrial art. Id; Crouwel, supra note 484, at 155, 161-63; van der Put \& Komarnicki, supra note 486 , at $198-206$.

492. These categories were limited mainly to toys, dolls, and jewelry plus two-dimensional designs. Before adoption of the separability criterion in the late $1950^{\circ} \mathrm{s}$, and after it first opened the door to applied art in 1948, the Copyright Office had accepted a motley array of articles for registration. See 1 M. NIMMER, supra note 1, § 2.08[B][3], at 2-89. Assessment of the Copyright Office's registration policy as regards any simgle object, however, must be tested against the regulation then in force and the policy objectives being pursued at the time.

493. See supra notes $456-70$ and accompanying text. During the same period, not a single case involving the overall shape of a modern functional design, true "industrial designs" in the sense that the Register used this ternt in his 1961 Report, see supra note 287, seems to have reached even the litigation phase in the cases reported; few, if any, penetrated the copyright fortress. The most cited critical commentary to take the opposite view is, of course, the 1971 article by the Chicago Critics, supra note 142 . See infra note 496 and accompanying text. 
bitrary and inconsistent decisions concerning applied art 494 that provide supporters of the unity of art thesis with their nost powerful ammunition. ${ }^{495}$

The Chicago Critics' attack on the excesses of the copyright approach in the United States thus seems premature and exaggerated. ${ }^{496}$ The feeble barriers to copyrightability of ornamental designs, manned with success from 1959 to 1969 , did not give way, nor did the expansive phase reported for this period actually occur until the 1970's. ${ }^{497}$ Meanwhile, because the Copyright Office had contrived to defend its fortress, by ineans that remain to be explored, ${ }^{498}$ a United States special design law, had it been passed prior to the 1970's, could still have kept most ornamental designs out of copyright law by means of a strict doctrine of separability not yet riddled with serious exceptions. Fifteen years after Mazer v. Stein, the inost accurate assessment of the situation was still that of Professor Latman, who observed that the copyright law was affording "too few designs with too much protection." 499

Ironically, when the courts of the United States, like many of their foreign counterparts, later reacted by elevating the threshold standards of creativity and origmality in copyright law, it was the Chicago Critics' 1971 article that was repeatedly cited as authority for the need to cut back upon copyright protection for industrial art. ${ }^{500}$

3. The Unity of Art Heresy. Although the Copyright Office had succeeded in defending the American copyright fortress against the unity of art forces that had been its foe all along, ${ }^{501}$ the weakness of the

494. Accord Latman, supra note 9, at 281-84. But see $1 \mathrm{M}$. NIMMER, supra note $1, \S 2.08$ [B]]3], at 2-88 to 2-90.

495. See supra notes $426-27$ and accompanying text.

496. The Chicago Critics may have imtended their criticism of the copyright approach to prod Congress toward enacting the design bill; at least they appeared to endorse such a solution. Chicago Critics, supra note 142, at 824-25.

497. The Chicago Critics were in time to report one of the first cases that portended future developments. See, e.g., Tennessee Fabricating Co. v. Moultrie Mfg. Co., 421 F.2d 279, 283 (5th Cir.), cert. denied, 398 U.S. 928 (1970).

498. See infra text accompanying notes 533-62.

499. Latman, supra note 9, at 284-85; cf. supra note 430 (situation in the Netherlands).

500. See, e.g., L. Batlin \& Son v. Snyder, 536 F.2d 486, 492 (2d Cir.)(en banc), cert. denied, 429 U.S. 857 (1976); see also Kieselstem-Cord v. Accessories by Pearl, Inc., 632 F.2d 989, 999 (2d Cir. 1980)(Weinstein, J., dissenting); Esquire, Inc. v. Ringer, 591 F.2d 796, 804 \& n.26 (D.C. Cir. 1976), cert. denied, 440 U.S. 908 (1979). See generally Reichman, After the Copyright Act, supra note 65.

501. See S. LADAS, supra note 2, at 859 (Ladas considers defense against the unity of art thesis to have been the purpose of Regulation $\$ 202.10$ (c) of 1959). The opposition of the United States authorities to the French position dates back to 1925, at least. Id at 836; see supra note 91. 
Office's position was clear. ${ }^{502}$ By 1971, the legal profession had been alerted to the possibility that Regulation Section 202.10(c) was analytically unsound. As drafted in 1959, this regulation disqualified even a "unique and attractively sliaped" article from copyright protection as a work of art if its "sole intrinsic function . . . is its utility."503 Yet, as the Chicago Critics pointed out, "tliere are no two-dimensional works and few three-dimensional objects whose design is absolutely dictated by utilitarian considerations." 504 In order to ward off new mandamus actions likely to raise questions about the Copyright Office's practices in this period, ${ }^{505}$ the Office redoubled its efforts to win legislative approval of a special design law. Action during the ninety-second and ninety-third Congresses, in 1974, resulted in the Senate's approval of the pending design bill for the fourtl time, ${ }^{506}$ but no corresponding action ensued in the House. As Congress tarried, the position that the Copyright Office had maintained for over a decade came under attack and grew untenable.

In a number of decisions, courts liad already begun to note the ambiguities of the separability criterion. In 1970, the United States Court of Appeals for the Fifth Circuit found copyright registration of "a [twelve-inch square] architectural inetal casting unit intended for use ... [as] a decorative screen or rooin divider" valid and infringed. ${ }^{507}$ In 1972, the Second Circuit simply assunied that the design of a flower pot-"an octagonal planter, which is a stylized container"-was copyrightable subject matter within section $5(\mathrm{~g})$ of the

502. In 1969 Professor Latman declared that the difficulty of administering the current regulations was "one of the reasons for the support by the Copyright Office of specialized legislation protecting designs." Latman, supra note 9, at 282. He added: "It would appear that in the absence of another such form of [design] protection . . . [t]he predictable result would be coverage of an increasing number of works within a scheine of protection that fits only imperfectly." Id. at 285; see also REGISTER's DRAFT REPORT 1975, supra note 36, ch. VII, at 12.

503. See supra note 199.

504. Chicago Critics, supra note 142, at 812. This assumed that Regulation Section 202.10(c) contained the operative definition of a useful article for purposes of determining copyrightability under the separability criterion. But the Copyright Office did not seen to share this assumption. See supra note 459; infra notes 513-16 and accompanying text.

505. See Compendium of Copyright Office Practices, supra note 459, at 2-274.

506. 120 CONG. REC. 30,477-30,516 (1974); REGISTER'S DRAFT REPORT 1975, supra note 36, ch. VII, at 21. In 1969, the Senate Judiciary Subcommittee had first reported an amended version of the design bill as Title III, later Title II, of the general revision bill. The design bill that the Senate passed in 1974 was Title III of the general revision bill. See Kadden, Copyright Law, in 1978 ANNUAL SURVEY OF AMERICAN LAW 593, 595; supra notes 351-52 and accompanying text.

507. Tennessee Fabricating Co. v. Moultrie Mfg. Co., 421 F.2d 279, 280 (5th Cir.), cert. denied, 398 U.S. 928 (1970). Defendants had copied by using the unit to make a nold and market the identical product. 
1909 Act. ${ }^{508}$ In 1973, the Second Circuit also affirmed the validity of a registration certificate acknowledging "castings for fixtures, pedestals, lamps, and furniture" to be copyrightable subject matter. ${ }^{509}$ None of these cases asked why registration had been granted in the first place. ${ }^{510}$

One explanation is that the Copyright Office inay have grown more discriminating in the use it made of the "sole intrinsic function" test set out in section 202.10 (c)..$^{511}$ The flower pot and the room divider arguably possessed some nonutilitarian functions. They might quahify as works of art within one reading of the express terins of the regulation because they were also "unique and attractively shaped." 512

A better explanation is that, in the early 1970's, the Copyright Office followed its own internal definition of a "useful article" and not the definition that the practicing bar thought section 202.10(c) contained.513 According to the 1973 revision of the Compendium of Copyright Office Practices, the Copyright Office was distinguishing between copyrightable "ornamental articles" and "useful articles" subject to the test of separability. Ornamental articles included "all decorative articles designed primarily to beautify"; useful articles included "all arti-

508. Hub Floral Corp. v. Royal Brass Corp., 454 F.2d 1226, 1227 (2d Cir. 1972). The only issue of law regarded publication; the court accepted the fact that the subject matter had been copyrighted as a work of art.

509. L. \& L. White Metal Castings Corp. v. Cornell Metal Corp., 353 F. Supp. 1170, 1171 (E.D.N.Y. 1972), affd, 177 U.S.P.Q. (BNA) 673 (2d Cir. 1973). The district court, rejecting a defense based on originality, said: " 411 the castings have been examined with care and it is concluded that all of the plaintiff's castings were properly copyrighted." Id. at 1173; accord L. \& L. White Metal Casting Corp. v. Joseph, 387 F. Supp. 1349, 1352 (E.D.N.Y. 1975)(metal castings nsed as components in lainps and lighting fixtures); see also S.K. Potteries \& Mold Co. v. Sipes, 192 U.S.P.Q. (BNA) 537 (N.D. Ind. 1976)(certificate of registration issued for molds for ceramic Christunas ornainents; validity not determined).

510. For the breadth of protection that the Second Circuit afforded applied art from 1970 to 1976, see generally Reichman, After the Copyright Act, supra note 65, at 298-303 ("Excesses of the Copyright Approach").

511. See supra note 199.

512. This conld be true, if the first senteuce of Regulation Section 202.10(c) is assumed to be a de facto definition of useful articles, which is a big assumption, see supra note 459; or if this first senteuce is read to mean that if the sole intrinsic function of an artiele is not its utility, [then] the fact that it is unique and attractively shaped will qualify it as a work of art. Professor Nimmer may have doubts about this reading. See $1 \mathrm{M}$. NiMMER, supra note 1, \$2.08[B][3], at 2-94; see also id. at 2-96.2.

Moreover, if such reasoning is attributed to the Copyright Office in regard to cases at this period, it would mean that the Register had accepted voluntarily the very argumeut she contested a few years later, im Esquire, Inc. v. Ringer, 414 F. Supp. 939 (D.D.C. 1976), rev'd, 591 F.2d 796 (D.C. Cir. 1978). On the contrary, even after the district court in Esquire interpreted the regulation as suggested above, the Register claimed a discretionary right to ignore this "gap" in her defenses pending remedial legislative action. See infra note 557 and accompanying text.

513. See supra note 459. 
cles designed primarily to serve a utilitarian function."514 The Compendium suggests that the second category was denied copyrightability as a matter of course. An atteinpt to distinguish between primarily "ornainental" or primarily "useful" evokes a criterion that courts in Germany used prior to the Second World War to administer their regime of partial cumulation on the basis of a prevalence of artistic over functional elements. ${ }^{515}$ Use of such a "prevalence" or "aesthetic surplus" test by the Copyright Office could explain soune apparently mconsistent registrations, but would depart from the theory of dissociation, which officially governed im Regulation Section 202.10(c).

The Copyright Office had returned to a more orthodox use of dissociation by 1975.516 Another explanation for the registrations in question inay be that the Copyright Office had begun to rely on the doctrine of conceptual separability in addition to the test of material separability that had sufficed in the 1960's. ${ }^{517}$ Conceptual separability can result from the possibility of appreciating a work independently of the object in which it is embodied.518 If the copyrightability of the flower pot, the room divider, and castings of sundry useful articles is tested by conceptual separability, none of them would seem capable of existing independently as works of art when separated from their functional, material supports. ${ }^{519}$ If, nonetheless, it be assumed that such designs

514. Compendium of Copyright Office Practices, supra note 459, at 2-274; see also Norris Indus. v. ITT Corp., 696 F.2d 918, 921-23 (11th Cir. 1983)(acknowledging Compendium).

515. For many years German courts distinguished noncopyrightable industrial designs from works of applied art according to "a greater or lesser degree of acsthetic content." Reimer, supra note 91, at 40-42. This is the "aesthetic surplus" or prevalence test, criticized by Ulmer as a misleading concept. E. ULMER, supra note 7, at 147. A similar test was used in French law prior to the triumph of the umity of art doctrine. See supra note 57. See generally Reichman, After the Copyright Act, supra note 65 , at 337-38.

516. Hearings 1975, supra note 169, at 1857 (testimony of Ringer, who mentions conceptual separability, but not the practice used in 1973); see supra note 340 .

517. "[A]ll original two-dimensional designs for useful articles . . . were subject to copyright registration. The same was true of those three-dimensional designs that can be conceptually separated and are capable of existing independently of the utilitarian aspects of the article embodying thein . . ." REGISTER's DRAFT REPORT 1975, supra note 36, ch. VII, at 12 (emphasis added). The 1975 Report seems to be the first in which the Copyright Office speaks officially of "conceptual separability" and not just separability.

518. See supra notes $218-21 \& 404-10$ and accoinpanying text.

519. In 1975, the Register gave no precise definition of conceptual separability, except to opine that "as it later evolved," the doctrine umight cover "very abstract designs, but it still can be identified as something that is desigued rather than the shape of the article [as] such." Nevertheless, "three-dimensional designs that can be conceptually separated" must also be "capable of existing independently of the utilitarian aspects of the article einbodying them." Hearings 1975, supra note 169 , at 1857 (testimony of Barbara Ringer).

If the castings qua castings could not exist independently as works of art, see supra notes 46770 and accompanymg text, they might still portray useful articles and thns seek registration on the same terms as drawings and photos of useful articles or as plastic works of a technical character. 
could exist separately and independently as works of art, then the refusal of courts to regard the "troughs, waves and lines" used by a fannous designer in a distinctive shoe design as also producing a conceptually separable artistic effect seens contradictory. ${ }^{520}$ The design of the rooun divider could also be viewed as materially separable froin its casting and despositable in two-dimensional form. But in this event, the "troughs, waves and lines" of the shoe design would seem equally susceptible of this rationalization. Furthermore, if all of the items inentioned above-and eventually ornamental ceramic molds of Christmas decorations as well 521 - were consistent with a theory of dissociation now grown "metaphysical" indeed, 522 then it seems mconsistent, and even arbitrary, to deny protection to other designs no less utilitarian in character, ${ }^{523}$ such as a furmiture design, ${ }^{524}$ a typeface de-

In this event, the castings might indeed be copyrightable under section 5(i) of the Copyright Act of 1909. But the useful articles manufactured from them-according to the precedents devolving from Baker $v$. Selden - should no more be protected than any other useful article manufactured from a copyrighted two-dimensional drawing or photo that had been deposited prior to manufacture. Baker v. Selden, 101 U.S. 99 (1880); see supra notes 307-08, 330-32 and accompanying text. These well-settled precedents were frozen into law, after the compromise of 1963, by section 111 of the pending revision bill, which became section 113 of the 1976 Copyright Act. 17 U.S.C. § 113 (a), (b) (1982).

520. SCOA Indus. v. Famolare, Inc., 192 U.S.P.Q. (BNA) 216 (S.D.N.Y. 1976). "It is concluded, in agreement with the Copyright Office, that the troughs, waves, and lines which appear on the shoe sole cannot be identified and do not exist independently as works of art." Id. at 218. On what was then a very shaky alternative ground, but is now a better reason-in the Second Circuit-than that given, the court found that the design "lack[s] even the minimum originahty needed for copyright." Id; see L. Batlin \& Son v. Snyder, 536 F.2d 486, 490-91 (2d Cir.)(en banc), cert. denied, 429 U.S. 857 (1976); Reichman, After the Copyright Act, supra note 65, at 31221 ("Farewell Alfred Bell").

Famolare's quest for some form of legal protection for his design appears from the following cases: Famolare, Inc. v. Edison Bros. Stores, Inc., 202 U.S.P.Q. (BNA) 373, 381 (N.D. 11l. 1979), affd without opinion, 618 F.2d. 111 (7th Cir.)(design patent invahd), cert. denied, 446 U.S. 984 (1980); USM Corp. v. Famolare, Inc., 202 U.S.P.Q. (BNA) 127, 128-29 (D. Minn. 1978)(design patent not infringed even if valid); Famolare, Inc. v. Melville Corp., 472 F. Supp. 738, 747 (D. Hawaii 1979)(mark invalid for functionality, no passing off, misappropriation rejected); Famolare, Inc. v. Edison Bros., 525 F. Supp. 940, 948 (E.D. Cal. 1981)(design patent invalid).

Contrast the finding of the Patent Examiner, who held this design to be "nonobvious" in issuing the design patent, with the finding of the District Court for the Southern District of New York, supra, which held that it lacked the minimun originality (creativity?) for copyright purposes. See Reichman, After the Copyright Act, supra note 65, at 303-08.

521. S.K. Potteries \& Mold Co. v. Sipes, 192 U.S.P.Q. (BNA) 537, 537 (N.D. Ind. 1976).

522. Latman, supra note 9, at 282.

523. The 1959 Regulation, section 202.10 (c), "offered no ready answer to the linedrawing problem inherent in delineating the extent of copyright protection available for works of applied art." 1 M. NIMMER, supra note $1, \$ 2.08[B]$, at 2-89.

524. See Gustave v. Zuppiger, 24 Ariz. App. 557, 540 P.2d 176 (1975). In discussing the scope of common law copyright for a work of art, this court rejected the separability test employcd by the Copyright Office as inconsistent with Mazer v. Stein. Id. at 559, 540 P.2d at 178; see Latman, Copyright Law, in ANNUAL SURvey of AMERICAN LAW 638-39 (1976). 
sign, ${ }^{525}$ or the design of an outdoor lamp..$^{526}$

An attempt to protect outdoor lighting fixtures under the design patent law had proved abortive when the Court of Appeals for the Third Circuit, in 1972, endorsed the strict standard of nonobviousness that the Second Circuit had continued to apply to combination design patents even after Graham v. John Deere. ${ }^{527}$ A few years earlier, the Supreme Court's Sears-Compco decisions had prevented unpatentable lamp designs from obtaining protection under the misappropriation doctrine of state unfair competition law..$^{528}$ Only copyright law seemed to provide a defense against predators in an industry im which plagiarism was endemic. ${ }^{529}$ When the Copyright Office declined to register a three-dimensional design of a modern outdoor lighting fixture-devoid of ornamentation-as a sculptural work of art, the manufacturer sued the Register in the now famous case of Esquire, Inc. v. Ringer. ${ }^{530}$

The Register framed the issue in terns of section 202.10(c) by insisting on the utilitarian character of the lamp, designed to illuminate parking lots. The Copyright Office disqualified the lamp from protec-

525. Eltra Corp. v. Ringer, 194 U.S.P.Q. (BNA) 198, 200-01 (E.D. Va. 1976), affd on other grounds, 579 F.2d 294 (4th Cir. 1978); see Kadden, supra note 506, at 595-99.

In Italian law, some question arises as to whether typeface designs are to be considered twoor three-dimensional designs; under the prevailing view it is the two-dimensional aesthetic effect that controls. Z.O. ALGARDI, supra note 61, at 261; M. FABIANI, supra note 96, at 45 . Nevertheless, Italian courts lave prevented protection of typeface designs in copyright law on the grounds that their artistic values are inseparable (inscindibile) from the industrial product with which typeface designs are associated. Z.O. ALGARDI, supra note 61, at 262. Typeface designs are protectible as ornamental designs under the Italian Design Law of 1940. Id. at 26I-62.

An International Convention for the Protection of Typeface Designs was negotiated at Vienna in 1973, at the end of a diplomatic conference on the protection of industrial property sponsored by WIPO. Id. at 262-65.

526. Esquire, Inc. v. Ringer, 414 F. Supp. 939, 941 (D.D.C. 1976), rev'd, 591 F.2d 796 (D.C. Cir. 1978), cert. denied, 440 U.S. 908 (1979).

527. 383 U.S. 1 (1966); see Rains v. Niacqua, 406 F.2d 275, 276-77 (2d Cir.), cert. denied, 395 U.S. 909 (1969); Hadco Prods., Inc. v. Lighting Corp. of Am., 312 F. Supp. 1173, 1185 (E.D. Pa. 1970), vacated sub nom. Hadco Prods., Inc. v. Walter Kidde \& Co., 462 F.2d 1265 (3d Cir.) (invahdated for obviousness), cert. denied, 409 U.S. 1023 (1972). The Third Circuit's decision in Hadco closed a brief but interesting flirtation with design patents. See, e.g., Rains v. Cascade Indus., 402 F.2d 241, 247 (3d Cir. 1968). The design treated with some sympathy in this decision was rejected out of ltand by the Second Circuit in Rains v. Niacqua. This decision was then invoked in Hadco. See supra notes 413-17 and accompanying text.

528. See supra notes 423-24 and accompanying text.

529. In our industry. . . design piracy is not unusual and seems to be on the increase. As one instance of the cynical attitude... in some quarters I might mention the remarks of the presideut of one of the largest lighting fixture inanufacturers .... When asked about the size of his company's design staff lie replied that they employ very few designers because there is a lot of plagiarism in the industry.

Design Protection Hearings 1961, supra note 21, at 105 (statement of W.F. Blitzer); see supra notes 292 (views of Fisher), 424 (possible uses of Lanham Act $\$ 43(\mathrm{a})$ ).

530. Esquire, 414 F. Supp. 939 (D.D.C. 1976), rev'd, 591 F.2d 796 (D.C. Cir. 1978), cert. denied, 440 U.S. 908 (I979); see supra note 188. 
tion under the 1909 Act as interpreted by the regulation because its aesthetically appealing features could not be separately identified as a work of art distinct from the shape as a whole..$^{531}$ Esquire contended that its design qualified as a work of art within the meaning of section $5(\mathrm{~g})$ of the 1909 Act and that it had been excluded solely because of its utilitarian purpose in contravention of Mazer v. Stein ${ }^{532}$

Judge Gesell brushed aside the doctrine of scindibiltà, invoked by the Register, as an "elusive semantic dispute."533 This obliged the Register to expose the principles actually being used to implement the criterion of separability. The Register's official answer was bold. In 1976, after nearly twenty years without a design law, the principle still controlling the copyrightability of applied art in the United States was said to be exactly what it had been from 1910 to 1958: "art in the historical and ordinary sense." 534 According to the Register, this principle accounted for the continumg exclusion of "shapes and forms of . . . useful articles," a result that avoided "trade restraints of up to 56 years in industrial designs of everything from automobiles to bathtubs to dresses." 535

The Register's deceptively simple answer ignored the different 1neanings that "art in the historical and ordinary sense" had acquired over time. Until 1948, this phrase connoted the dichotomy between beauty and utility. ${ }^{536}$ In the mid-1950's, it signified an object that was "clearly a work of art in itself." 337 By the 1960's, the phrase appeared to mean art materially separable from the utilitarian article with which it was associated.538 Sonretine in the 1970's, it had come to mean "art that was physically or conceptually separable,"539 a more elastic formula consistent with the theory of dissociation as fully developed in Italian case law and literature. ${ }^{540}$ The Register's reference to "art in the historical and ordinary sense" in 1976 thus obscured the question of

531. Esquire, $414 \mathrm{~F}$. Supp. at 940 . So the issue was framed in 1976 under Register Ringer; but under the 1973 Compendium of Copyright Office Practices the lamp design may have been per se noncopyrightable, as defendant claimed. See supra notes 513-15 and accompanying text.

532. See Note, Copyright Law, 25 WAYNe L. Rev. 923, 929 (1979)(quoting Plaintiffs Brief at 4).

533. Esquire, 414 F. Supp. at 941.

534. Id; see supra notes $15-18,179-80$ and accompanying text.

535. $414 \mathrm{~F}$. Supp. at 941.

536. See supra notes $15-18$ and accompanying text.

537. See supra notes 172-73, 182-83, 194-95 and accompanying text.

538. See supra notes $199,462-66$ and accompanying text.

539. But see supra notes $513-15$ (period of prevalence test).

540. See supra notes 216-26 and accompanying text. But see supra notes 405-10 and accompanying text. 
what the Copyright Office now understood by "conceptual separability."

Instead of dismissing separability out of hand, Judge Gesell might have asked Register Ringer why she deemed Esquire's lainp less conceptually separable than other nontraditional subject inatter permitted registration in the 1970's. ${ }^{541}$ A decade and a lialf earlier, Register Fisher, who had introduced the separability requirenent in 1958,542 answered a question no less pertinent to the present inquiry. When asked during the Design Protection Hearings of 1960 wliether the Copyright Office used "a test which does apply esthetic value" in determining the copyrightability of ornainental designs, Fisler replied: "We are doing that now. It is an impossible situation, but I agree with you that it is now on our slioulders." 543

Register Fisher sought to mitigate the impact of this answer by mentioning the need for works of art to meet a de minimis standard of creativity.544 Quite apart from legitimate concern with the de minimis rule, use of a test of artistic value to distinguish designs rising to the level of works of art from lesser, noncopyrightable designs remained an "impossible situation." 545 In 1960, soine two years after the introduction of scindibiltà into United States copyright law, the Register was still using a test that appears inore consistent with the "clearly a work of art" standard of the 1956 regulation. ${ }^{546}$ Leading Italian commentators regard a test of artistic value as consistent with the doctrine of conceptual separability. Indeed, most observers of the Italian system, whether native or foreign, believe that a finding of conceptual separa-

541. The district court in Esquire did consider that the Register's past practice in registering household lamps and candlesticks was inconsistent with the denial of registration to this lainp. 414 F. Supp. at 941 . But this follows from too quick a dismissal of the separability criterion as mere semantics. See supra text accompanying note 533 .

542. See supra notes $197-99$ and accompanying text.

543. Design Protection Hearings 1960, supra note 115, at 83.

544. Technically, this could bring the matter under Regulation Section 202.10(b), see supra note 199, which requires "some creative authorship." In this context, Fisher also attempted to rationalize Bailie v. Fisher (which denied protection to a five-pointed star) in terms of the de minimis standard. But both Bailie and Vacheron arose under the 1956 regulation ("clearly a work of art" standard), and the exclusion of the high-styled watch face design in Vacheron was obviously not due to the de minimis rule. See Design Protection Hearings 1960, supra note 115, at 8283; supra text accompanymg notes 173-78, 184-88. Fisher was obliged to admit that other categories of copyrightable subject matter were not subjected to a "de minimis" standard that directly assessed artistic value. Design Protection Hearings 1960, supra note 115, at 82-83.

545. Design Protection Hearings 1060, supra note 115, at 83. Since S. 2075, supra note 158, attempted to exclude ornamental designs einbodied in useful articles froin the copyright law altogether, the inference was that Fisher could be reheved of his "impossible situation" by passage of S. 2075. This assertion was undoubtedly true. See supra text accoinpanying notes 264-71.

546. See supra text accompanying notes 181-82. 
bility means that a given ornamental design exhibits a high degree of artistic intensity. ${ }^{547}$

Fisher's 1960 statement suggests that conceptual separability, in the United States as in Italy, depended largely on the degree of aesthetic value manifested by the design in question. Nontraditional designs admitted in the 1970's should therefore have reflected a high degree of artistic intensity if their acceptance for registration turned on conceptual separability. ${ }^{548}$ Yet cases litigated during this period never mention the issue, despite knowledgeable application of the material separability criterion in at least one major decision. ${ }^{54}$ Such discussion might have explained why Esquire's outdoor lamp design was less conceptually separable than the designs of the flower pot, rooin divider, and castings that did obtain registration certificates.

If the Register excluded Esquire's lamp design because it was intended for a utilitarian purpose, as Esquire contended, the Register's decision was inconsistent with its own regulations and with Mazer $v$. Stein, although not necessarily with the anomalous Compendium of Copyright Office Practices of 1973.550 If the Register rejected Esquire's design because it lacked sufficient artistic value to be considered "conceptually separable," the Copyright Office had distinguished Esquire's lamp design from other designs admitted in the 1970's on the basis of subjective value judgments lacking either statutory or judicial authority. ${ }^{551}$ Finally, if the Register excluded Esquire's lamp because the Copyright Office clamied a discretionary right to deny registration to modernistic shapes and fornus of useful articles as inherently imseparable from their material supports, this amounted to a conclusive presumption that such designs could never attam the degree of artistic intensity needed to qualify as true works of applied art. 552 Yet flower pots, room dividers, and castings for household goods seein, by inference, to have possessed such qualities.

547. See supra notes $405-10$ and accompanying text.

548. At least one such design did reflect a high degree of artistic intensity-the design of a belt buckle-although hitigation did not arise until after the 1976 Copyright Act. Kieselstein-Cord v. Accessories by Pearl, Inc., 632 F.2d 989, $991-94$ (2d Cir. 1980); see Reichman, After the Copyrigit Act, supra note 65 , at $324-40$.

549. See supra notes $467-70$ and accompanying text.

550. See supra note 459 , notes $513-16$ and accompanying text.

551. See Gustave v. Zuppiger, 24 Ariz. App. 557, 559, 540 P.2d 176, 178 (1975)(furniture designs). This court rejected the federal regulation as leading to "a subjective inquiry into the definition of art," contrary to Mazer v. Stein. Id. at 559, 549 P.2d at 178; see supra text accompanying note 186 (Judge Clark's dissent in Vacheron).

552. In essence, this argument proved successful on appeal, but only after Congress had incorporated the separability doctrine imto the new definition of pictorial, graphic, and sculptural works in the 1976 Act (17 U.S.C. § 101 (1982)). See Esquire, Inc. v. Ringer, 591 F.2d 796, 803 (D.C. Cir. 1978), cert. denied, 440 U.S. 908 (1979); Reichman, After the Copyright Act, supra note 65, at 35065 (noncumulation in the District of Columbia Circuit). 
It seems undeniable that the Copyright Office subjected Esquire's lamp to an in cainera proceeding, without expert witnesses and without a record, in which administrative value judgments about either the design in question or a disfavored category of designs defeated registration. 553 The result is hard to reconcile with other decisions of the same period even if the Register's decisions about art were invested with a presumption of validity. ${ }^{554}$ Here at last were the niconsistent decisions-"discouraging for their subtlety"sss - that plague foreign regimes of noncunulation and partial cuunulation alike. Holdings of this apparently arbitrary nature have induced even French commentators skeptical of the umity of art thesis to prefer overprotection of industrial art in copyright law under a systen of total cumulation to the inequities seen in coinpeting regimes within the Berne Union. 556

The Register demanded the right to implement Regulation Section 202.10 (c) with the same discretion as before "while the [design] bills wend their way through the legislative process."557 Judge Gesell rejected her demand. Because the "outdoor hights serve both to decorate and to illuminate" and were "exclusively decorative" during the day, their "sole exclusive function" could not be utility. Every attractively shaped useful article has the additional function of being decorative..$^{588}$ On this reasoning, the "sole intrinsic function" test was eliminated as a barrier to copyrightability of aesthetic designs. 559

553. See, e.g., Reed, supra note 427, at 42; Reichman, After the Copyright Act, supra note 65 , at 373-86. In Berne Union countries, there is no registration process and the issue of copyrightability only arises as a defense to an infringenent action.

554. Judge Clark, in Vacheron, had criticized the Copyright Office for assuming "judicial or discretionary functions such as has the Commissioner of Patents," whose decisions to issue a patent are entitled to a presumption of validity. See supra notes 186-88 and accompanymg text; 1 D. Chisum, PATENTS, supra note $367, \S 5.06[2]$. These presumptions, however, are routimely ignored in the design patent cases. See, e.g., Frantz Mfg. Co. v. Phoenix Mfg., 457 F.2d 314, 326 (7th Cir. 1972); see also Reichman, After the Copyright Act, supra note 65, at 373-86 (discussing 17 U.S.C. $\S \S 410,411$ (1982), which ntay have enlarged the Register's discretionary power).

555. Desbois, supra note 60, at 74. Of niterest in this connection is the Copyright Office's own flattering estimate of these same "industrial designs" in its 1975 Supplementary Report to Congress, in which it extolled the "large body of fine three-dimensional designs" left unprotected as "creative works," the products of "a field involving a high degree of creativity." REGISTER's DRAFT REPORT 1975, supra note 36, ch. VII, at 12, 21 (enphasis added).

556. See supra text accompanying note 81; Françon, supra note 27, at 102-03; Gaubiac, supra note 48, at 62-63, 66-70. Compare I M. NIMMER, supra note 1, § 2.08[B], at 2-96.3 to 2-96.4: "[U]nless and nntil special design legislation is adopted, if the choice is full copyright protection or none at all, it nay be that the former alternative is preferable to the latter." See generally Reichman, After the Copyright Act, supra note 65, at 365-86.

557. Esquire, 414 F. Supp. at 941.

558. Id.; see $1 \mathrm{M}$. NiMMER, supra note $1, \S 2.08[\mathrm{~B}]$, at 2-91.

559. The belief of the practicing bar that this fornulation, as the definition of a useful article, constituted a barrier was now disabused. The Chicago Critics had pointed out this "gap." Chicago Critics, supra note 142, at 812 , in 1971 . But this fornulation was probably not the operative 
The court then replaced both "separability" and "art in the historic sense" with the broad reading of Mazer $v$. Stein that had lain dormant since the Copyright Office announced its first official interpretation of the Supreme Court's decision in 1956:560 there "cannot be and there should not be any national standard of what constitutes art and the pleasing forms of the Esquire fixtures are entitled to the same recognition afforded more traditional sculpture."561 Judge Gesell spoke for an influential segment of the international copyright community when he declared that the "forms represented by Esquire's fixtures emphasize line and shape rather than the realistic or the ornate but it is not for the Register to reject them on artistic grounds . . . or because the form is accommodated to a utilitarian purpose." 562

A few months later, the Register's separability criterion was rejected again at the district court level, in Eltra Corp. v. Ringer. ${ }^{563}$ The Copyright Office had denied registration, on grounds of imseparability under section 202.10 (c), to a typeface design developed by a professional designer at considerable cost. ${ }^{564}$ The court disagreed: "Typefaces should no more be denied registration on the theory that the letters theniselves have an underlying function separate from [their] artistic designs than could registration be denied the statuettes in $\mathrm{Ma}$ zer." 565 The typeface design was accordingly a work of art within the meaning of section $5(\mathrm{~g})$ of the 1909 Act, although unprotectible because

definition of a useful article at all, and its demise may simply have underscored the weak legal foundation on which the Copyright Office stood without a statutory mandate. See supra note 459 and text accompanying notes 513-16.

560. See supra notes $44,141$.

561. Esquire, $414 \mathrm{~F}$. Supp. at 941 . Judge Gesell may have sought to narrow his holding by bringing it within past interpretations of the Copyright Office that allowed registration of "lighting in combimation with sculpture." If so, this effort seems swept away by the broader implications of the language quoted. See Latman, supra note 524, at 638.

562. Esquire, 414 F. Supp. at 941 (citing Bleistein v. Donaldson Lithographing Co., 188 U.S. 239 (1903) and Mazer v. Stein); see Kadden, supra note 506, at 598. The remarks of Judge Gesell are quoted and amplified by Professor Nimmer. See $1 \mathrm{M}$. NimMER, supra note 1, § 2.08[B], at 296.2 to 2-96.3. Compare the views of Judge Gesell and Professor Nimmer with the views of Pouillet summarized in the text supra, at notes 61-67. Consider also the comments by Nimmer, Derenberg, and Ringer, supra note 347.

563. 194 U.S.P.Q. (BNA) 198 (E.D. Va. 1976), modified, 579 F.2d 294 (4th Cir. 1978). Eltra was decided on October 26, 1976, a few months after Esquire v. Ringer $I$ (May 5, 1976), 414 F. Supp. 939 (D.D.C. 1976), which it does not cite.

564. Kadden, supra note 506, at 597. At the time of decision, Congress had just adopted the 1976 Act's definition of "pictorial, graphic, and sculptural works" ( $\$ 101)$, "an implicit congressional endorsement of the dividing line drawn in . . . regulation [\$ 202.10(c)]." Id. at 596; see infra text accompanying notes 644-47. That the Register ultimately won was therefore not surprising, but the court's reasoning was.

565. Elira, 194 U.S.P.Q. (BNA) at 200; see supra note 525. 
Congress had acquiesced in "the long-standing Copyright Office practice of refusing to register typeface designs." 566

This period, in which even the Second Circuit had entered upon a unity of art phase remarkable for its lack of restramt,, 567 thus culminated in two district court decisions that rejected the theory of dissociation. Although these holdings were to be overruled after enactment of a general revision bill, 568 they temporarily opened the door to broad protection of ornamental designs of useful articles under the new United States copyright law, just as Arthur Fisher predicted would occur if Congress insisted on "doing nothing." 569

Suddenly, designers and manufacturers in the United States, like their counterparts in France, stood to gam copyright protection on relatively soft terms for a duration of life plus fifty years. ${ }^{570}$ If, as the Register insisted, this opening of "the floodgates to copyrighting . . . industrial designs" would inhibit competition, the district court's answer in Esquire, Inc. v. Ringer was that congressional approval of sui generis design legislation should be obtained. "In the interim," however, "the Register cannot avoid the Supreme Court's interpretation of the copyright law."571

4. Grand Finale allitaliana. The predicament in which the Copyright Office found itself even before the district court's decision in Esquire must be carefully assessed. In 1975, the Register reiterated the Copyright Office's long-standing support for the design bill then pending as Title II of the general revision bill and urged Congress, by this ineans, to rescue the "large body of fine three-dimensional designs" otherwise denied full copyright protection under existing law. ${ }^{572}$ The pending bill was essentially the same as that put forward in 1965 , subject to certam interim amendments and clarifications. ${ }^{573}$

566. 194 U.S.P.Q. (BNA) at 201. On appeal, the Fourth Circuit affirmed the result but repudiated the lower court's reasoning. The validity of the Copyright Office regulations was upheld; typeface designs were not works of art under $\$ 5(\mathrm{~g})$ of the 1909 Act. Eltra Corp. v. Ringer, 579 F.2d 294, 297 (4th Cir. 1978); see Reichman, After the Copyright Act, supra note 65, at 350-65.

567. See Reichman, After the Copyright Act, supra note 65, at 298-308.

568. See generally Reichman, After the Copyright Act, supra note 65, at 350-65.

569. See supra text accompanying note 294 .

570. See Latman, supra note 524, at 639 . If registered as a work made for hire under $\$ 302(\mathrm{c})$ of the 1976 Act, the duration would be 75 years. 17 U.S.C. $\$ 302$ (c) (1982).

571. Esquire, 414 F. Supp. at 941 ; accord Eltra Corp. v. Ringer, 194 U.S.P.Q. (BNA) 198, 202 (E.D. Va. 1976), modified, 579 F.2d 294 (4th Cir. 1978). But what, in fact, was the Supreme Court's imterpretation of the copyright law in view of the questions begged in Mazer v. Stein? See supra text accompanying notes 139-47.

572. REGISTER's DRAFT REPORT 1975, supra note 36, ch. VII, at 12, 21; see supra note 352.

573. REGISTER's DRAFT REPORT 1975, supra note 36, ch. VII, at 12-13; see supra text accompanying notes 325-36. Interim amendments had added a renewal term of five years, for a total of ten years maximum protection. See S. 22, Title II (The Design Protection Act of 1975), 
In theory, the proposed legislation implemented the compromise arrangements of the 1960's, includimg the anti-inaim rule, as a result of which the criterion of separability would continue to govern relations between copyright law and the special design law. 574 Even before Esquire, the efficacy of this package deal had been undermmed by the growing inability of the Copyright Office to sustam the exclusionary force of its separability criterion without the aid of a design law. The "constant expansion of the copyright concept of works of art" that ensued ${ }^{575}$ seriously challenged the noncuinulatiomst premise around

$\$ 205$, in Copyright Law Revision, Report of the Senate Comm. ON the Judiciary, S. Rep. No. 473, 94th Cong., 1st Sess. 39-47 (1975), reprinted in 13 OmNibus Copyright Revision LegisLATIVE HistoRY (1977); H.R. 2223, Title II, Hearings 1975, supra note 169, at 66-70; Latman, supra note 296, at 358. A procedure for administrative screening of applications for registration had also been added and then joined with the opposition proceeding originally made available to third parties. Id. at 358. This was not to be a search of the prior art. Technical language concerning the exclusions from protectible subject matter and the requisite burden of originality liad been refined, id., although these were still not free from ambiguity. See infra text accompanying notes 582-98.

Of more immediate importance was a pending shift in the time that protection was to commence, nainely, from the date of publication to the date of registration, which would have substituted an industrial property concept for a softer, copyright concept. This cliange liad been requested by the Patent Office in order to move the United States design law more imto line with foreign design laws, which stress certainty and notoriety. Hearings 1975, supra note 169, at 167 (testimony of Tegtmeyer); REgISTER's DRAFT REPORT 1975, supra note 36, ch. VII, at 22. But see Hearings 1975, supra note 169, at 1002-03 (testimony of Latman). The foreign norms, which (except for France) require registration and impose forfeiture for prior divulgation, have been criticized as too burdensome for artisans and small or medium-sized producers. See Duchemin, supra note 71, at 184-85; Reichman, After the Copyright Act, supra note 65, at 366-73. Other technical matters pertaining to Title II are diseussed in REOISTER's DRAFT REPORT 1975, supra note 36, ch. VII, at 21-24. For a detailed analysis of a successor to Title II, H.R. 20, which sheds light on the complexities of Title II, see generally Fryer, supra note 244.

The regime of dual protection, which permitted users to opt for either the "design copyright" of Title II or a design patent under existing law, was still imtact despite the proposal to stiffen the registration requireinent under Title II. REGISTER'S DRAFT REPORT 1975, supra note 36, ch. VII, at 12. See supra notes 253-56. But see Report of THe PRESIDENT's Commission ON THE Patent System, Senate Comm. on the Judiciary, Subcomm. on Patents, Trademarks and CopyRIGHTs, 90th Cong., Ist Sess., Doc. No. 5, February 2, 1967 [hereinafter cited as President's Commission], at 20 (recommending repeal of design patent statute, or adoption of sui generis design law). See also Latman, supra note 9, at 285 . Had the Congress followed this rccommendation, it could have undermined the effectiveness of the speeial design law, with its inherent subject inatter ambiguities. But the recommendation to repeal the design patent law was quietly forgotten and, by 1975, the dual regime was again taken for granted. See, e.g., Hearings 1975, supra note 169, at 995 (testimony of Latman); H. REP. No. 1476, supra note 352, at 54.

574. REGISTER's DRAFT RePORT 1975, supra note 36, ch. VII, at 12-13; see supra notes 274-78, 295-302, 573.

575. Hearings 1975, supra note 169, at $997-98$ (testimony of Latman); see also Nolan, supra note 10 , at 216 . 
which the United States scheme of special design protection had been built. ${ }^{576}$

a. Toward an American regime of partial cumulation. By the mid-1970's, the Copyright Office thus stood to gain relatively little from strict comphance with the compromise agreements of the 1960's. ${ }^{577}$ The most advantageous solution for the Office would instead have been the adoption of a regime of partial cumulation. ${ }^{578}$ Such a regime typi-

576. See supra notes 200-01, 330-36 and accompanying text. The Register, aware of this disarray, pointed out in 1975 that some 9600 two- and three-dimensional designs of useful articles had qualified for copyright registration, in a single fiscal year, compared to 3600 design patents issued in the same period. REgISTER's DRAFT REPORT 1975, supra note 36, ch. VII, at 12. Compare supra note 194 (figures for 1959-1960).

577. The Register continued to stress that "there had been no expressed opposition to the design bill in either House since it was joined to the copyright bill in 1969" aside from the traditional opposition of the Justice Department, which was offset by the favorable stance of the Commerce Department. REGISTER's DRAFT REPORT 1975, supra note 36, ch. VII at 14, 22; see supra notes 292, 350; Reichman, After the Copyright Act, supra note 65, at 352-61. The picture painted by the Register may have been too rosy. Other sources suggest that there was informal opposition behind the scenes from major industries, mcluding sectors of the automobile industry, and froin the manufacturers of spare parts. Opposition by the latter group was traditional and had been expressed at hearings on other design bills. See, e.g., Design Protection Hearings 1965, supra note 114; see also supra notes $292,351$.

Tension between big industry, which may favor a patent-type design law, and small or medium-sized industry, which may favor a copyright approach in one form or another, is reported in foreign hiterature. Compare, for example, a recent survey in the Federal Republic of Germany showing big industry in favor of a patent-type design law, see B. ENGLERT, supra note 6, at 82; Euglert, supra note 96, at 778-79, with the views of Duchemin, see Duchemin, supra note 71, at 184-85; Duchemin, supra note 2, at 73-77 (which are closer to the views of Arthur Fisher, supra note 267 ).

578. The special design law, expected to pass in the late 1950's, had not been enacted by 1975 ; quick passage of a design bill was the quid pro quo for the Register's consent to the deals struck with the opposition. See supra text accompanying notes 295-300, 348-52. The Copyright Office now risked breaking faith with the limited protectionist legacy of Arthur Fisher in the name of a compromise tainted by a failure of consideration. See supra notes 257,266 ; text accoinpanying notes $287-90,294$.

In 1975, the Register drew the attention of Congress to the systemic anomalies that lad accumulated after nearly two decades of separability without a design law. Under the General Revision of Copyright Law that was about to be enacted, privileged items such as "textile designs, wallpaper, foor tiles, painted or primted decorations, 'ccrtain' lamp bases, carvings on furniture, costume jewelry, [and] decorator items" could all presumably acquire protection lasting life plus fifty years. REGISTER's DRAFT REPORT 1975, supra note 36 , ch. VII, at 12 . Although this parade of horribles was meant to persuade Congress how unjust it was to leave modern functional designs altogether unprotected, the argument cut both ways. It was, after all, the Copyright Office that continued to keep functional designs out while all the rest had got im. Moreover, the design bill as drafted did not cancel existing privileges unless a copyright proprietor or potential copyright proprietor decided to seek special design protection, in which case the copyright would be forfeited as to apphications of the design to useful articles offered to the public. See supra notes 334-35 and accompanying text.

To the unity of art school, the logical response was now to let even inodernistic designs in, rather than adopt a law to keep thein out. See, e.g., Nolan, supra note 10, at 223-24. In other words, the design law after the compromises would at the inost have exerted pressure towards eliminating the very long term of protection for categories privileged under Mazer $v$. Stein, with- 
cally blocks access to copyright law by elevating the threshold subjectmatter standards that imdustrial art, as distinct froin other copyrightable works, must satisfy. ${ }^{579}$ The regulation that Register Fisher issued in 1956 did in fact establish the basis for such a regime in United States law. But its development was aborted in 1958 when the Vacheron court implied that Fisher's criterion- "clearly a work of art in itself"-was incompatible with both Bleistein and Mazer. ${ }^{580}$ The question is whether there had occurred any subsequent change in the legal environment that unade some analogous solution feasible once again in the 1970's.

The answer inay be found in the "historic docking" that occurred when the design bill, heretofore pending as a separate legislative proposal, becaine an integral part of the general revision bill in 1969.581 The subject matter requirements of this design bill introduced new technical premises into the overall scheine. For example, section 202(b) of Title II, as it stood in 1975, excluded ornamental designs of useful articles from design protection if such designs were "staple or commonplace, such as a standard geoinetric figure, familiar symbol, einblem or inotif, or other shape, pattern or configuration which has becoine common, prevalent or ordinary." 582 Section 202(c) further excluded froin protection under Title II any designs that differed froin the designs excluded by section 202(b) "only in insignificant details or in elements which are variants commonly used in the relevant trades."583 Section 203, however, allowed protection under Title II when "the design is a substantial

out saving the copyright fortress, unless the Copyright Office had ancillary means of defense at its disposal not revealed in the 1975 Report. For the view that it did, see infra text accompanying notes 581-624.

579. See supra notes 131, 279-83 and accompanying text; Reichman, After the Copyright Act, supra note 65 , at $271-97,333-40,366-73$.

580. See supra notes 173, 186-203 and accompanying text. Had Register Fishcr, armcd with this regulation, see supra note 173 and accompanying text, managed to exclude the high-styled watch face design of the Vacheron case in 1958 without incurring the Second Circuit's displcasure, a fortiori all designs of lesser artistic value, regardless of past privileges accorded to thcir respective subject matter categories, could likewise have been excluded from copyright law and relegated to a sui generis design law once enacted. But Vacheron had impeded further development of a rudimentary regime of partial cumulation on this basis.

581. See supra notes 351-52 and accompanying text.

582. S. 22, Title II, Protection of Ornamental Designs of Useful Articles, supra note 573. The same language appeared in Title II, H.R. 2223, supra note 573. In both bills, the crucial links between Titles I and II were forged by incans of $\S 113$ of Title I and of the definition of a useful article set out in $\S 101$ of Title I and then repeated in $\S 201(b)(1)$ of Title II.

583. S.22, supra note 573. Section 202(a) of Title II excluded designs that were "not original"; $\S 202$ (d) excluded designs "dictated solely by a utilitarian function of the article that embodies it"; and $\S 202(e)$ excluded three-dimensional designs pertaining to wearing apparel. 
revision, adaptation, or rearrangement" of a design otherwise excluded by sections $202(\mathrm{~b})$ through (d). ${ }^{584}$

These provisions of Title II were, and remain, ambiguous. Most sponsors and supporters of the design bills insisted that "originality in the copyright sense" was the primary requirement: the candidate design must have been created without copying. ${ }^{585}$ Originality in the sense of independent creation was, however, expressly required by section 202(a) of Title II; hence this interpretation renders section 202(b) through (c) and section 203 superfluous to some extent. ${ }^{586}$ Some observers have suggested that sections 202 and 203 amounted to a de facto requirement of novelty without nonobviousness, ${ }^{587}$ a solution that the drafters of the Uniform Benelux Designs Law favored in 1966.588

584. Id. (emphasis added); cf. Copyright Act of 1976, 17 U.S.C. $\S 103$ (1982)(concerning derivative works).

Because $\$ 202$ (d) excluded designs "dictated solely by [a] utilitarian function," the broad rehabihitative language of section 203 , which on its face applies to all of $\S 202$, including $\S 202$ (d), could have opened the door to protection of utility models. Fryer, supra note 244, at 168 (discussing a later version of the design bill (H.R. 20)); Pretty \& Durant, supra note 367, at 201. This ambiguity appears to have been an oversight in the drafting process, and Professor Fryer's interpretation provides a workable solution. Fryer, supra note 244, at 168. Coinpare the effects of an analogous oversight upon the copyright law of the United Kingdom, supra note 132.

585. See, e.g., supra notes 244, 255, 267 (discussing authorities related to S. 2075, the 1959 bill); see also Latman, supra note 296, at 358; Design Protection Hearings 1961, supra note 21, at 158 (testimony of Cary).

Title II of S. 22 as passed by the Senate would create a new limited form of copyright protection for "original" designs which are clearly a part of a useful article, regardless of whether such designs could stand by themselves, separate from the article itself. Thus designs of useful articles which do not ineet the design patent standard of "novelty" [nonobviousness?] would for the first time be protected.

H. REP. No. 1476, supra note 352, at 50.

586. See supra notes 244,583 and accompanying text. Both the Department of Justice and certain sectors of industry thought an "originality" standard too low. See, e.g., Design Protection Hearings 1960, supra note 115, at 19 (letter froin Lawrence E. Walsh, Deputy Attorney General), 85, 88 (letter from Harry R. Mayers, General Patent Counsel, General Electric Co.).

587. See In re Nalbandian, 661 F.2d 1214, 1218 (C.C.P.A. 1981) (concurring opinion of Rich, J.). Sections 202 and 203 of Title II, S. 22, supra note 573, nay have opened the door to considerations of prior art. Consider, inost recently, the following observation of Professor Fryer, supra note 244, at 166 (discussing provisions of H.R. 20, 97th Cong., Ist Sess. (1981), which were the same in this respect as the sections of Title II discussed here):

It is a fact . . that to the list of requirements already mentioned, the useful article, ornamental appearance, and originahty must be added a requirement found in Section 902(b) similar to, but not the same as, "novelty" and a requirement in Section 902(c) that is similar to but not exactly the same as "unobviousness."

See supra note 247.

588. Uniform Benelux Designs Law, arts. 1, 4, supra note 117; see supra note 430.

In the United States, it was thought that Judge Rich's decision in In re Laverne, 356 F.2d 1003 (C.C.P.A. 1966), which opened a split in the circuits, was intended to introduce a standard of novelty without nonobviousness. Until recently, the Court of Customs and Patent Appeals insisted that nonobviousness in design patents should be tested against an ordinary observer standard rather than the presumably stricter ordinary designer standard followed by most other circuits. See 1 D. ChISUM, supra note 367, § 1.04[2][f], at 1-130 to 1-134. The Court of Customs and Patent Appeals, which has now been succeeded by the Court of Appeals for the Federal 
These positions are not inherently irreconcilable within the peculiar environment of design protection law, wliere preconceptions based strictly on a "copyright" or a "patent approacli" may obscure the real complexity of the issues. ${ }^{589}$ Insistence at the subject matter stage that a candidate design should manifest sufficient creative content to distance itself from the prior art, and especially from public domain matter, may serve a number of useful purposes. One is to limit the kind of automatic protection that the "design copyriglit" might otherwise confer upon designs of low or neghigible creativity.590 Another is to reduce the potential for harassment actions against manufacturers who honestly create their own designs from public domain material..$^{591}$ At the same time, allowing independent creation as a defense to an infringement action encourages fair followers, and excuses the inanufacturer who in good faith hits upon a protected design innovation. ${ }^{592}$ Protection against copying also avoids inuch of the rigidity and unwieldiness of the patent-law paradigm, which, under the proposed regime of dual protection, would liave become an obstacle only if absolute protection against independent creation were desired. ${ }^{593}$ A liybrid design law that

Circuit, abandoned the ordinary observer test in 1981. In re Nalbandian, 661 F.2d 1214, 1216 (C.C.P.A. 1981).

It is far from clear that the standard that Judge Rich advanced required novelty only, as this term is used under the present design patent law. Indeed, a novelty requirement divorced from a requirement of qualitative originality or nonobviousness tends to become more stringeut than when it is jomed to this additional requirement. See Reichman, After the Copyright Act, supra note 65, at 293-97 (Uniform Beuelux Designs Law). What Judge Rich really wanted was not this or that standard so much as an effective design protection law. See In re Nalbandian, 661 F.2d at 1218-19 (concurring opinion of Rich, J.).

589. Ljungman, supra note 147, at 117 ; sẹe supra note 147 and accompanying text.

590. Protection becomes automatic at the infringement stage in cases of slavish imitation, although the duration is relatively short. See supra text accompanying notes 482-83. Professor Latman, who demied that S. 2075 (1959) imposed a test of novelty, nonetheless agreed that "the design cannot be so staple or commonly known as to lack a minimun of creativity." Design Protection Hearings 1960, supra note 115, at 70 (testimony of Latman); see supra note 247 (full quote). In both design law and copyright law, the unanswered question was-and remains-how minimum is minimum.

591. In copyright law, the Second Circuit became concerned about the issue of harassment after 1976. See, e.g., Durham Indus. v. Tomy Corp., 630 F.2d 905, 910-11 (2d Cir. 1980); L. Batlin \& Sons v. Snyder, 536 F.2d 486 (2d Cir. 1976)(en banc), cert. denied, 429 U.S. 857 (1976); see also Reichman, After the Copyright Act, supra note 65, at 312-21, 340-50 (discussing these cases).

592. See supra notes 254,491 and accompanying text.

If you consider designs at a low creative level . . . a heavy risk exists for identical achievemeuts without copying. . . . A manufacturer can always avoid infrimgemeut . . . by not copying existing designs. . . . But . . . he is badly protected as to designs which he has himself produced without copying .... This risk imcreases with a less pronounced requiremeut for design creativity.

Ljungman, supra note 147, at 123. For Register Fisher's view that "actual copying" was all that design protection should cover, see supra note 254.

593. See supra note 573; supra notes $243-46,254$ and accompanying text. 
protected against copying only, despite a creativity requirement, 594 would in some respects have resembled the design law of the Federal Republic of Germany as originally drafted in 1876.595

Whatever dimensions sections 202 and 203 might have assumed once Title II was enacted, ${ }^{596}$ they clearly required of ornamental designs some measure of quantitative creativity 597 not expressly required for works of applied art under either the originahty requirement of Title I or the pre-1976 case law, notably Alfred Bell \& Co. v. Catalda Fine Arts, Inc. ${ }^{598}$ If so, the integrated law could not reasonably continue to afford seventy-five to one hundred years of copyright protection under Title I to industrial art manifesting inerely distinguishable variations from designs in the public domain or from designs still in copyright under either title. Logically, Title I would have to demand at least the same degree of quantitative creativity required for ten years of "design copyright" protection under sections 202 and 203 of Title II. ${ }^{599}$

594. "Protection under Title II of S. 22 was like copyright in several ways . . . The protection under the bill was unlike copyright in other ways." Kadden, supra note 506, at 595 n.19.

595. Law Concerning Copyright in Designs, January 11, 1876, art. 1, 5, Federal Republic of Germany, supra note 96 . This "design copyright" law continues to protect against copying only, but its subject matter requirements have drifted upwards to the point where both novelty and qualitative origmality (nonobviousness) are now required. See, e.g., B. ENGLERT, supra note 6, at 50, 78. The Federal Republic also protects utility inodels. See supra notes 378-81 and accompanying text.

596. Title II was never enacted; see infra notes $641-44$ and accompanying text.

597. See A. LATMAN, supra note 160, at 24-26.

598. 191 F.2d 99, 104 (2d Cir. 1951). With reference to pre-1976 case law, the requirement of originality even for works of applied art was satisfied when the author added something recognizably his own without simply copying a preexisting work. See, e.g., Monogram Models v. Industro Motive Corp., 492 F.2d 1281, 1284 (6th Cir.), cert. denied, 419 U.S. 843 (1974); Puddu v. Buonamici Statuary, Inc., 450 F.2d 401, 402 (2d Cir. 1971); Alfred Bell \& Co. v. Catalda Fine Arts, 191 F.2d 99, 102-03 (2d Cir. 1951). These cases suggested that any "distinguishable variation" that was "more than trivial" would suffice if the work was otherwise independently created. A separate requirement of creativity as such had been perceived and enlarged by district court decisions in the artificial fiowers cases of 1968, see supra note 456; but by 1970 the Second Circuit had aligned the requisite degree of creativity, even for applied art, with the modest quantum that otherwise satisfied the requirement of originality. See, e.g., Thoinas Wilson \& Co. v. Irving J. Dorfman Co., 433 F.2d 409, 411 (2d Cir. 1970), cert. denied, 401 U.S. 977 (1971); Puddu v. Buonamici Statuary, Inc., 450 F.2d 401, 402-03 (2d Cir. 1971).

Ostensibly, Title I was to codify the modest originality requirement of $A$ lfred Bell. S. 22, Title I, $\S 102$, supra note 573; S. REP. No. 473 , supra note 573 , at 50 ("the phrase 'original works of authorship,' which is purposely left undefined, is intended to incorporate without clange the standard of originality established by the courts under the present copyright statute"). H.R. 2223, Title I, $\S 102$, Hearings 1975, supra note 169. Both $\S 102$ of Title I, S. 22, supra note 573, and the excerpt from the Senate Report bear the date 1975; this means they both referred to "the standard of originality established by the courts" prior to L. Batlin \& Sons v. Snyder, 536 F.2d 486 (2d Cir.)(en banc), cert. denied, 429 U.S. 857 (1976).

599. Although $\S 102$ of S.22, Title I, supra note 573 (the predecessor of 17 U.S.C. $\S 102$ (1982)), was to codify the standard of originality established by the courts, see supra note 598 , the district courts in the Second Circuit were in open revolt, by 1975, against the standard of Alfred 
And if a test of quantitative creativity had become necessary to avoid short-term protection of staple, commonplace, or familiar designs, then it would seem equally logical to require a much higher standard of creativity for ornamental designs seeking long-term protection as apphed art under Title 1.600

As to ornamental designs in general, a minimum level of creative content would suffice for purposes of Title I1. As to works of applied art, courts and administrators anxious to implement the pohcies behind the integrated statute ${ }^{601}$ could construe Title I as implicitly subjecting ornamental designs to a requirement of substantial creativity when more than the short-term protection of Title II was sought. ${ }^{602}$ If such a solution subtly remtroduced the derogation from Bleistein rejected in Vacheron, ${ }^{603}$ the end result would lave paralleled developments in the Berne Union in which leading European member countries were taking steps to elevate the standard of copyrightability for works of applied art once broad-gauged special design reforms went into effect. ${ }^{604}$

The introduction of substantive barriers to copyright protection of apphed art at the subject matter stage might then have excluded all ornaniental designs of useful articles-including toys, dolls, and costume jewelry-that were either commonplace or otherwise deficient in creative content. 605 The fact that such designs, or even fabric designs, might incidentally satisfy a criterion of material separability would then have proved unavailing. ${ }^{606}$ This approach could also have compensated for the relative inability of courts to narrow the scope of pro-

Bell as the Second Circuit had been interpreting it in cases involving applied art since 1970. See generally Reichman, After the Copyright Act, supra note 65, at 297-321 (quantitative creativity in the Second Circuit).

600. Only copyright protection, i.e. protection against copying, was given under either Title, and independent creation remained a perfect defense.

601. See supra notes 257-71 and accompanying text (discussing the policies behind S. 2075).

602. For the evolution of the doctrine of substantial creativity from 1976 on, see generally Reichman, After the Copyright Act, supra note 65.

603. Such a derogation was to prevail in the Second Circuit from 1976 to the present day. See supra note 602.

604. For discussion of the trend in foreign law towards regimes of partial cumulation, see supra notes 279-83 and accompanying text. Of chief interest for present purposes were the Benelux countries, which agreed in 1966 to restrict concurrent copyright protection to designs of "marked artistic character" once the Uniforin Benelux Designs Law, supra note 117, took effect im 1975. See supra note 430 . The Nordic countries present another example. See infra text accompanying note 624.

605. Relevant precedents were the artificial flower cases of 1968: Florabelle Flowers, Inc. v. Joseph Markovits, Inc., 296 F. Supp. 304 (S.D.N.Y. 1968)(copyright of commonplace design invalid); Gardenia Flowers, Inc., v. Joseph Markovits, Inc., 280 F. Supp. 776 (S.D.N.Y. 1968)(design invalid for Iack of creativity and originality).

606. See supra note 341 (remarks of Cary). Works already in copyright would not have been divested. See S. 22, Title I, \& 113(d), supra note 573. 
tection otherwise accorded copyrighted designs of low creativity when taken by slavish imitation. Yet most ornamental designs that were not commonplace should have continued to meet the test of quantitative creativity laid down by sections 202 and 203 of Title II even if they lacked the substantial creativity that might logically be required for long-term protection in Title I. ${ }^{607}$ These designs would not, therefore, have been cast into the public domain, nor should they have required assistance from tradeınark and unfair competition laws prior to establishing verifiable secondary meaning. Instead, the result would have been to foster the objective of keeping inost ornainental designs out of copyright law and in a special design law. 608

Much indirect evidence suggests that the Copyrigltt Office perceived the advantages of switching to a regime of partial cuinulation. ${ }^{609}$ In 1966, only three years before the integration of Titles I and II, the Benelux countries had accepted a stiff exclusionary standard for applied art, to take effect January 1, 1975, cast in the following terms: "A design having a marked artistic character may be protected both by this [design] law and by the copyright laws if conditions for the application of both legislations are met."610 The key phrase in this provision resembled that of the first exclusionary criterion set forth by Register Fisher in his 1956 regulation, which permitted copyright registration if the object, although a useful article, was "clearly a work of art in itself." 611

Register Fisher had thus anticipated the Benelux standard and had continued to employ a test of aestlietic value even after the 1959 regulation formally adopted the theory of dissociation. ${ }^{612}$ In edging the offcial regime of noncumulation, later couched in terms of conceptual separability, closer to foreign regimes of partial cumulation based on aesthetic value, Fisher and his successors had, in effect, aligned thein-

607. See supra notes $255-56$ and accompanying text. One function of continuing the design patent law in effect was to exert downward pressure on the subject inatter requireinents of the special design law and in this way increase its receptivity. For the different ineanings of substantial creativity in United States law after 1976, see supra note 602.

608. See supra uotes $264-66$ and accompanying text; text acconipanying note 241 (quote froin Ringer); uote 347 (views of Derenberg).

609. For evidence that the Copyright Office has used a modified version of this strategy under the 1976 Act, see Reichman, After the Copyright Act, supra note 65, at 373-82 ("Strengths and Weaknesses of the Competing Doinestic Models" (citing cases)).

610. Uniform Benelux Designs Law, art. 21(1), supra note 117 (einphasis added). For the controversy this provision has recently stirred up, see Reichman, After the Copyright Act, supra note 65, at 293-97. Developments in foreign law were of continuing concern to the United States authorities. See, e.g., Hearings 1975, supra note 169, at 171 (testimony of R. Tegtineyer).

611. See supra note 173 and accoinpanying text.

612. See supra notes $542-46$ and accompanying text. 
selves with those Italian commentators who hold that the Itahan doctrine of conceptual separability should lead toward a regime of partial cumulation, based on a test of aesthetic content, as in the Federal Republic of Germany. ${ }^{613}$ Moreover, in 1973, the Compendium of Copyright Office Practices exhibited the framework for a regime of partial cunulation that was already inconsistent with the criterion of separability in Regulation Section 202.10(c). ${ }^{614}$

If, in the early 1970 's, fostering a regime of partial cumulation thus constituted a plausible strategy for the copyright authorities, it nonetheless clashed with the anti-inaim compromises of the 1960's, which had gutted Register Fisher's proposals in S. 2075.615 One would naturally expect the general revision bills pending smce 1965 to have codified the separability criterion of the 1959 regulation in conformity with these compromise arrangements. But this cannot be verified. The Register's Report of 1965 stated ouly that "copyright in a pictorial, graphic or sculptural work will not be affected if the work is employed as the design of a useful article," without reference to the doctrime of separability. ${ }^{616}$ Similarly, no reference to separability has been found in any of the 1975 revision bills, either in Title II or in the definition of "pictorial, graphic and sculptural works" in Title I, which laconically declared that

"Pictorial, graphic, and sculptural works" include two-dimensional and three-dimensional works of fine, graphic, and applied art, photographs, prints and art reproductions, inaps, globes, charts, plans, diagrams, and nodels..$^{617}$

613. See supra text accompanying note 547 ; notes $405-10$ and accompanying text.

614. See supra note 459 and text accompanying notes 513-16. The Copyright Office had also attempted to restrict copyrightability by proposing in 1961 that the general revision bill should recognize only works manifesting "an appreciable amount of creative authorship." See supra note 311 and accompanying text. This attempt to elevate the basic subject matter requirements of American copyright law proved abortive. Id. But see 17 U.S.C. \& 102(a) (1982)("works of authorship"). It nonetheless demonstrated that the policy framework within which both the 1956 regulation as overtly administered and the 1959 regnlation as covertly administered were generally coherent. See supra notes $182-83,541-45$ and accompanying text.

615. See supra text accompanying notes 295-302, 330-36.

616. ReGister's RePORT 1965, supra note 298, at 47; H. REP. No. 83, 90th Cong., 1st Sess. 17 (1967), reprinted in 11 OMNIBUS COPYRIGHT REvISION (1976); see supra note 298 and accompanying text.

617. S. 22, Title I, \& 101, supra note 573; H.R. 2223, Title I, \& 101, supra note 573. No separability language appears elsewhere in the 1975 revision bills, and this was also true of the 1965 bill. See supra note 298. In at least one report, separability is used to explam past practice; but there is no unequivocal expression of intent as to future practice. See REGISTER's DRAFT REPORT 1975, supra note 36, ch. VII, at 13. Apart from such informal references, prior to the Final Act in 1976, no draft version of the general revision bill has been found that contained a single mention of the criterion of separability. 
Nothing in these same bills guaranteed that copyrightability for works of apphed art would in fact continue to be governed by the doctrine of separability. ${ }^{618}$ Only Regulation Section 202.10(c), which claimed to interpret Mazer $v$. Stein, continued to impose the doctrine of separability. ${ }^{619}$ Yet section 202.10 (c) would arguably become superannuated the moment Titles I and II were enacted into law as integral parts of a single reform bill.

A Copyright Office bent on switching to a regime of partial cumulation had, therefore, only to quash its 1959 regulation and replace it with a new one, derived by inference from sections 202 and 203 of Title II, that would impose, in one form or another, a doctrine of substantial creativity on all works thereafter claiming copyrightability as applied art. ${ }^{620}$ The inost elegant techinque might, indeed, have been to reissue a 1970's version of the "clearly a work of art in itself" criterion of Fisher's 1956 regulation. ${ }^{621}$ When challenged in the courts, the Copyright Office could have argued that this criterion now rested upon the foundation of Titles I and II, which miphed legislative rejection of long-term protection for most ornamental designs of useful articles from the grant of short-term protection for the same subject inatter. ${ }^{622}$ The Register might have reinforced this claim by echoing the conclusions that a high-level committee of inquiry had reached in Sweden when preparimg the new design law of 1970:623 "[A]s soon as an effective protection of registered designs on a pure novelty basis had been launched, there was no longer need for a tolerant copyright protection

618. In keeping with the "anti-maim" premise, which abolished the proposal for a "terminable copyright," works of art once admitted to copyrightability could not thereafter be expelled when embodied in the designs of useful articles. See, for example, S. 22, Title I, \& 113(b), (c), and its mirror image, S. 22, Title II, $\$ 227$ (b), supra note 573. The same language was used in H.R. 2223, supra note 573. If the owner of the copyrighted design einbodied in a useful article voluntarily sought to register for special design protection under Title II, then copyright protection would be lost as to the utilization in useful articles. S. 22, Title I, § 113(c), supra note 573; S. 22, Title II, $\$ 227$ (a), supra note 573 . But this gave no assurance that any particular criterion would be used to determine that an ornamental design was a work of art (i.e. a pictoral, graphic, or sculptural work) in the first instance.

619. See supra notes $198-99$ and accompanying text.

620. See supra notes 596-605 and accompanying text. As inatters turned out, after 1976 the Copyright Office latched onto the doctrine of substantial creativity developed by the United States Court of Appeals for the Second Circuit. Sce Reichman, After the Copyright Act, supra note 65, at 373-86.

621. See supra text accompanying note 173 .

622. See in this connection the express power to establish regulations "not inconsistent with law for the administration of the functions and duties . . under this title" granted to the Register by 17 U.S.C. $\$ 702$ (1982). See also 17 U.S.C. $\$ 410($ b) (1982)(Register's power to refnse registration when "the material deposited does not constitute copyrightable subject matter").

623. See supra note 117. 
of applied art. Thus, it was decided to . . raise the requirement for creativity substantially in connection with the new wording." 624

b. Noncumulation without a design law. The Copyright Office origimally used the Italian criterion of separability to thwart the possibility of interpreting Mazer $v$. Stein so as to adopt the Frencli unity of art doctrine. ${ }^{625}$ Although the exclusionary power of the separability criterion had undoubtedly been weakened im the course of time, ${ }^{626}$ the Copyright Office had nonetheless managed to avoid a direct test of its legality prior to the 1976 decision in Esquire, Inc. v. Ringer. ${ }^{627}$ Enactment of Titles I and II before 1976 would have relieved the pressure on separability and made it both plausible and feasible for the Copyright Office to implement a program of partial cumulation along the lines suggested above. But Esquire, together with other decisions tending to validate a broad reading of $\mathrm{Mazer},{ }^{628}$ undermined the criterion of separability before the design law of Title II could be adopted. These cases legitimated an American version of the unity of art thesis ${ }^{629}$ on the very eve of final adoption of the General Revision of Copyright Law underway since 1955. They also made it politically inexpedient for the Copyright Office to "reimplement" Mazer ${ }^{630}$ by mferring a doctrine of substantial creativity from the integration of Titles I and II, absent express legislative permission to derogate from Bleistein, which at this late date was unthinkable.631 Under the circumstances, the only option

624. Ljungman, supra note 147 , at 122 . Of considerable interest are the photographs of a modernistic coffee pot, chair, and telephone, all of which could obtain copyright protection prior to the new dispensation, $i d$. at $120-24$, under the Nordic Design Laws, supra note 117. The Uniform Benelux Designs Law was to achieve a similar result by ineans of the "marked artistic character" test of article 21.

625. See supra notes 196-203, 501 and accompanying text.

626. See supra notes 502-26 and accompanying text.

627. 414 F. Supp. 939, 941 (D.D.C. 1976), rev'd, 591 F.2d 796 (D.C. Cir. 1978), cert. denied, 440 U.S. 908 (1979); see supra text accompanying notes 550-62.

Professor Latman had pointed this out in 1969. Latman, supra note 9, at 282. In 1975, a state court had rejected separability in dealing with a common law copyright in a furniture design. See Gustave v. Zuppiger, 24 Ariz. App. 557, 559, 540 P.2d 176, 178 (1975); see supra note 524 and accompanying text.

628. See supra notes 521-26, 558-7I and accompanying text. For the broad reading of Mazer v. Stein, see supra notes $44,141$.

629. These cases relied on the broad reading of Mazer $v$. Sfein; for the inost recent exposition of this view, see $1 \mathrm{M}$. NIMMER, supra note $1, \S 2.08[\mathrm{~B}]$, at 2-96.2 to 2-96.4. See supra note 347 (views of Derenberg, Nimmer, and Ringer).

630. See supra note 198 and accompanying text.

631. "[T]he definition of 'pictorial, graphic, and sculptural works' carries with it no inphed criterion of artistic taste, aesthetic value, or intrinsic quality. The term is intended to comprise not only 'works of art' in the traditional sense but also works of . . . 'applied art.' "H.R. REP. No. 1476 (1976), supra note 352, at 54. In effect, an official switch to a regime of partial cumulation means suspending Bleistem v. Donaldson Lithographing Co., 188 U.S. 239 (1903), with regard to applied art. See supra note 620. The fate of Register Fisher's 1956 regulation after the Second 
then still open to a Copyright Office historically opposed to the unity of art position was to codify the regime of noncumulation allitaliana ${ }^{632}$ that opponents of S. 2075 had been promised since the 1960's. ${ }^{633}$

Sometime after May 1976, when the district court decided Esquire, the House Committee on the Judiciary was prompted to amend the Senate's version of the pending revision bill by adding the separability language im section 202.10(c) of the 1959 regulation almost verbatim to the definition of "pictorial, graphic, and sculptural works" in section 101 of Title I.634 Under the definition of "useful articles," also in section 101,635 ornamental designs of such articles, however aesthetically pleasing, would normally possess an intrinsic utilitarian function. ${ }^{636}$ The amended text thus subjected virtually all industrial art seeking copyright protection under Title I to the separability criterion of sections 101 and 102(a)(5), despite the district court's decision in Esquire. This doctrime of separability could then authorize the denial of copyrightability to modern, functional designs, a practice the Register had unsuccessfully tried to defend at the district court level in $E_{s-}$ quire. ${ }^{637}$ Such designs would obtain protection for up to ten years under the sui generis regime of Title II, which had already passed the Senate for the fifth time.638

Circuit's decision in the Vacheron case is instructive in this regard. See supra text accompanying notes 194-96.

632. See supra text accompanying notes 299-300, 333-36.

633. See supra notes $295-302$ and accompanying text.

634. See Copyright Act of 1976, 17 U.S.C. \& 101 (1982); 1 M. NimMER, supra note 1, § 2.08[B], at 2-93. Compare S. 22, $\S 101$ (1975), supra note 573 (no separability language in definition of "pictorial, graphic, and sculptural works") with 1976 Act, § 101, supra note 199 (containing separability language from former Regulation § 202.10(c) (1959)).

The criterion of scindibiltid was now on its way to official congressional endorsement at a time when the design bill itself, Title II, had already passed the Senate for the fifth time. See H.R. REP. No. 1476, (1976), supra note 352, at 50; Kadden, supra note 506, at 595-96 (citing bills by number). This definition of "pictorial, graphic, and sculptural works" replaced the term "works of art" in §5(g) of the 1909 Act. $1 \mathrm{M}$. NIMMER, supra note 1, § 2.08[B], at 2-93; see supra note 9.

635. In some earlier versions, this definition had been attached to the forerunner of section 113 (earlier section 111). But by 1975, the definition of useful article was located in section 101, where it ultimately resided. See $\S 101$, in H.R. REP. No. 2223 (1975), supra note 573; supra text accoinpanying notes $259,303-06,330-32$.

636. H.R. REP. No. 1476 (1976), supra note 352, at 55; 1 M. NiMmER, supra note 1, § 2.08[B], at 2-93, to 2-95. But there were plenty of ambiguities even if matters had gone as planned. See Reichman, After the Copyright Act, supra note 65, at 373-86.

637. See Esquire, Inc. v. Ringer, 591 F.2d 796, 798-99 (D.C. Cir. 1978), rev'g, 414 F. Supp. 939 (D.D.C. 1976); Reichman, After the Copyright Act, supra note 65, at 350-65.

638. See supra note 634. Section 113 of Title I meshed the two titles together and also ensured that copyright in a work that portrayed any useful article as such, whether or not patented, did not include the exclusive right to the article manufactured from the work that portrayed it. See, e.g., § 113, Title I, H.R. REP. No. 2223 (1975), supra note 573; § 111, 1965 Draft Bill, REGISTER's REPORT 1965, supra note 298, at 202 (predecessor of § 113) (comparative table). 
The new definition of pictorial, graphic, and sculptural works, combined with Title II of the pending revision bills, ${ }^{639}$ amounted to an American version of the Italian noncumulationist model. This scheme, unlike its Italian counterpart, did not provide for the protection of utility models. It sanctioned a dual regime of short-term design protection, below the line of demarcation with copyright law, that would have enabled users to choose between absolute protection under the design patent law and protection against copying under Title II. ${ }^{640}$

At least one foreign source under press at the time treated Title II as part of United States intcllectual property law. ${ }^{641}$ But the House Judiciary Subcommittee on Courts, Civil Liberties, and the Admimistration of Justice decided, in a closely divided vote, to strike Title I1 from the Senate's version of the general revision bill. ${ }^{642}$ The Conference Committee did not restore this provision to the Final Act before its enactment in October 1976.643 Further action on the design bill was suspended sine die. ${ }^{644}$

The 1975 version of $\S 113$ contained four subsections. Subsections (b), (c), and (d) deal specifically with the interrelationship of Title 1 and Title II. See H.R. REP. No. 2223 (1975), supra note 573. In Title II, $\S 227$ (b) related back to Title I and was the mirror image of $\S 113$ (b) as it stood in 1975. Id. (Title II, §227(a) reiterated the "anti-naim" rule, that Title II was not to curtail rights granted under Title I). Both $\S 113$ of Title I and $\S 227$ of Title II were then functionally linked by a common reliance on the definition of useful article. Kadden suggests that, without this provision, technical drawings or photographs of patented articles as such might have been denied protection against copying. Kadden, supra note 506, at 599-600.

639. See supra note 573 (citing S. 22 and H.R. 2223).

640. See supra notes 253-56; note 333 and accompanying text; note 584. The Italian model also offered a double regime of design protection below the copyright line in that users could choose between protection of an ornamental design and registration as a utility model . But both these regimes are yoked to the industrial property matrix, whereas, given the continuation of the United States design patent law, Title II might have operated largely on copyright principles. For the difference between Title II and the design patent law, see Kadden, supra note 506, at 594 n.11, 595 n. 19.

641. B. ENGLERT, supra note 6 , at 47 n.46, 74.

642. Conference Committe, General Revision of the Copyright law, Title 17 of the United States Code, Conference Report, H.R. Rep. No. 1733, 94th Cong., 2d Sess. 82 (1976), reprinted in 17 OMNIBUS Copyright Revision Legislative History (1976); Latman, supra note 524, at 639 n.80.

643. H.R. REP. No. 1733, supra note 642 , at 82.

644. Latman, supra note 19, at 315 n.1. When S. 22 reached the House Judiciary Committee following Senate passage, the Committee clected to delete Title II, giving as one of the principal reasons its uncertainty whether typeface designs should receive even the limited protection of Title II. See H.R. REP. No. 1476, supra note 352, at 50; Kadden, supra note 506, at 595.

The House Report expressed concern about a number of issues, including the proper administrative agency for design protection. H.R. REP. No. 1476, supra note 352, at 49-50. Deletion of Title II was to enable the House Judiciary Committee to give these and other issues "further study." Latinan, supra note 19, at 315 n.1. At least one source, however, attributes the deinise of Title II to "strong opposition to creation of a new form of intellectual property." Norris Indus. v. ITT Corp., 212 U.S.P.Q. (BNA) 754, 756 (N.D. Fla. 1981)(citing the Congressional Record), aff d, 696 F.2d 918 (11th Cir. 1983). Chairman Kastenmeier said: 
The General Revision of Copyright Law that emerged from the Conference Report was thus a mutilated version of the Register's last proposal. It retained the separability criterion in the new definition of "pictorial, graphic, and sculptural works," which reads as follows:

"Pictorial, graphic, and sculptural works" include two-dimensional and three-dimensional works of fine, graphic, and applied art, plotographs, prints and art reproductions, inaps, globes, charts, technical drawings, diagrams, and models. Such works shall include works of artistic craftsmanship insofar as their forn but not their inechanical or utilitarian aspects are concerned; the design of a useful article, as defined in this section, shall be considered a pictorial, graphic, or sculptural work only if, and only to the extent that, such design incorporates pictorial, graphic, or sculptural features that can be identified separately from, and are capable of existing independently of, the utilitarian aspects of the article. 645

The General Revision also retained the inclusive definition of useful articles: "A 'useful article' is an article having an intrinsic utilitarian function that is not unerely to portray the appearance of the article or to convey information. An article that is nornally a part of a useful article is considered a 'useful article." "646 But the reformed copyright law lacked the special regime of design protection that gave logical coherence to the Itahan system. ${ }^{647}$ By accepting the doctrine of scindibiltà and rejecting a special design bill, Congress, im the provisions signed

The final major area of controversy is title II of the Senate bill which provides for a new form of protection for ornamental designs which cannot be identified separately from the useful articles of which they are part. This "no man's land" between copyright and patent law presents difficult public policy questions. The Department of Justice strongly opposed the creation of this new form of intellectual property on the grounds that no need for it had been demonstrated. Because sufficient information was not available to enable the subcommittee to resolve the issue at this time, we deleted title II from the bill with the understanding that the subject would be considered in depth during the next Congress.

122 CoNG. REC. 31,979 (1976)

The opposition of the Justice Department had not been considered strong by the Copyright Office in 1975, REgISTER's DRAFT REPORT 1975, supra note 36, ch. VII, at 22, nor by witnesses at the 1975 hearings, see, e.g., Hearings 1975, supra note 169, at 1000 (testimony of Latman). Title II, furthermore, had the strong support of the Commerce Department. See Hearings 1975, supra note 169, at 167 (testimony of Tegtmeyer); see also Reichman, After the Copyright Act, supra note 65, at 352-61. At a recent public meeting Professor Latman expressed his opinion that it was Chairman Kastenmeier who opposed Title II. Association of American Law Schools, Section on Intellectual Property Law, The Scope and Limits of Trademark, Copyright and Patent Protection for Applied Art and Industrial Designs (conference at San Francisco, Jan. 8, 1984) (statement of Professor Latman)(available in recorded tape form).

645. 17 U.S.C. $§ 101$ (1982); see also 17 U.S.C. $§ 102(a)(5)$ (1982).

646. 17 U.S.C. $\$ 101$ (1982).

647. In the Conference Report, section 113(b), (c), and (d) of the 1975 bill were deleted from the final version, in keeping with the deletion of Title II, and section 113 was renumbered to becoine section 113(a)(1) and (2), without further change or comment regarding their meaning in the absence of the design bill. CONFERENCE REPORT 1976, supra note 642. It is in this form that the "mutilated" proposal entered the 1976 Act as sections 101 and 113. 
into law on October 19,1976, ensured continuation in the United States of a systein that was fundamentally flawed.

The design protection bill omitted from the Copyright Act (Title II) was remtroduced, with minor changes, in the first session of the 96th Congress as H.R. 2706, where it died in the House Judiciary Committee. J. Miller, U.S. COPYRIGHT DocumenTs 279 (1981). Essentially the same bill was repeatedly reintroduced as H.R. 20. See Fryer, supra note 244, at 164 \& n.2.

A new design bill has been introduced at the time of this writing. See 2 COPYRIGHT L. REP. (CCH) I 20,228 (1983). This bill, H.R. 2985, 97th Cong., 1st Sess. (1983), is essentially the same as H.R. 20. See also H.R. 1028, 97th Cong., 2d Sess. (1984) (Semiconductor Chip Protection Act of 1984), reprinted in 27 PAT. TRADEMARK \& Copyright J. (BNA) $645-48$ (1984). 